\title{
Authorial Turns: \\ Sophie Calle, Paul Auster and the Quest for Identity
}

(C) Anna Khimasia, 2007 


$\begin{array}{ll}\begin{array}{l}\text { Library and } \\ \text { Archives Canada }\end{array} & \begin{array}{l}\text { Bibliothèque et } \\ \text { Archives Canada }\end{array} \\ \begin{array}{l}\text { Published Heritage } \\ \text { Branch }\end{array} & \begin{array}{l}\text { Direction du } \\ \text { Patrimoine de l'édition }\end{array} \\ \begin{array}{l}\text { 395 Wellington Street } \\ \text { Ottawa ON K1A ON4 }\end{array} & \begin{array}{l}\text { 395, rue Wellington } \\ \text { Ottawa ON K1A ON4 } \\ \text { Canada }\end{array}\end{array}$

Your file Votre référence ISBN: 978-0-494-36802-2 Our file Notre référence ISBN: 978-0-494-36802-2

NOTICE:

The author has granted a nonexclusive license allowing Library and Archives Canada to reproduce, publish, archive, preserve, conserve, communicate to the public by telecommunication or on the Internet, loan, distribute and sell theses worldwide, for commercial or noncommercial purposes, in microform, paper, electronic and/or any other formats.

The author retains copyright ownership and moral rights in this thesis. Neither the thesis nor substantial extracts from it may be printed or otherwise reproduced without the author's permission.
AVIS:

L'auteur a accordé une licence non exclusive permettant à la Bibliothèque et Archives Canada de reproduire, publier, archiver, sauvegarder, conserver, transmettre au public par télécommunication ou par l'Internet, prêter, distribuer et vendre des thèses partout dans le monde, à des fins commerciales ou autres, sur support microforme, papier, électronique et/ou autres formats.

L'auteur conserve la propriété du droit d'auteur et des droits moraux qui protège cette thèse. $\mathrm{Ni}$ la thèse ni des extraits substantiels de celle-ci ne doivent être imprimés ou autrement reproduits sans son autorisation.
In compliance with the Canadian

Privacy Act some supporting forms may have been removed from this thesis.

While these forms may be included in the document page count, their removal does not represent any loss of content from the thesis.
Conformément à la loi canadienne sur la protection de la vie privée, quelques formulaires secondaires ont été enlevés de cette thèse.

Bien que ces formulaires aient inclus dans la pagination, il n'y aura aucun contenu manquant.

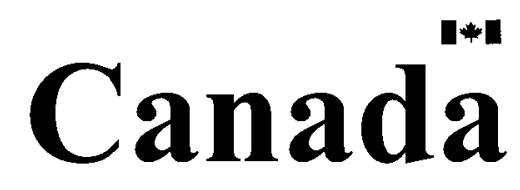




\section{Abstract}

\section{Authorial Turns:}

\section{Sophie Calle, Paul Auster and the Quest for Identity.}

This thesis examines contemporary French artist Sophie Calle's book Double Game and American author Paul Auster's novel Leviathan. Auster borrows Calle's projects for Maria, an artist character in his novel, and Calle then borrows Auster's novel for her projects. My study examines Double Game and Leviathan focusing on the moments at which authors and texts intertwine. By exploring literary constructs of authorship and the author's relationship to the text, I concentrate on Auster's and Calle's self-conscious play with their roles of and as 'author' and 'subject'--continually reinventing and repositioning their identity in relation to their fictional narratives. I expose how Calle's and Auster's authorial games disrupt the stability and fixity of identity by exploring the possibilities of a shifting plasticity that is always already "under-erasure." Authorship, representation and the structure of writing is deconstructed to expose the fiction(s) of identity. 


\section{Acknowledgements}

I would like to express a sincere thank you to all those who have helped and supported me in the process of completing this thesis. First and foremost I would like to thank my supervisor Jill Carrick whose enthusiasm and critical observations have been insightful, challenging and invigorating. I would also like to express my thanks to the Art History Department at Carleton particularly Professors Carol Payne and Ming Tiampo for their continued encouragement. My research trip to Paris would not have been possible without the generous support from The Friends of Art History, The Graduate Student Research Fund and the Art History Department.

My appreciation and thanks also go out to my classmates, particularly Rhiannon Vogl who offered her hand in times of frustration. I also thank my friend MarieFrance Lemay for introducing me to Sophie Calle and Therese Khimasia who read and reread my thesis endlessly. And most importantly, I thank Sean Lynch whose patience, enthusiasm and loving support enabled me to complete this endeavour. 


\section{Table of Contents}

List of Figures

Introduction: Authorial Turns

Methodology

vi

Chapter 1: Fact and Fiction and the Quest for Identity 8

Fact and Fiction: Paul Auster and Leviathan 8

Fact and Fiction: Sophie Calle and Double Game 11

Representation: Truth, Fiction, and Autobiography: PA 18

Representation: Truth, Fiction and Autofiction: SC 21

$\begin{array}{ll}\text { (De)Constructing Identity } & 21\end{array}$

Calle Performing Auster $\quad 24$

$\begin{array}{ll}\text { Conclusion } & 27\end{array}$

Chapter 2: Authorial Intrusions and the Presence of the Absent Referent

Author/Text Interrupted

\begin{tabular}{ll} 
Authorial Identity & 33 \\
\hline
\end{tabular}

The Authorial "Subject" $\quad 35$

Writing/Representation Interrupted 43

The Subject (of) Writing $\quad 50$

Conclusion $\quad 54$

Chapter 3: Detectives, Doublings and Displacements 56

$\begin{array}{ll}\text { Whose Story? } & 57\end{array}$

Auster/Aaron/Sachs/Dimaggio $\quad 58$

Maria/Lillian/Calle $\quad 64$

The Double in the Detective Genre $\quad 74$

$\begin{array}{ll}\text { The Role of the Reader } & 76\end{array}$

$\begin{array}{ll}\text { Traces } & 78\end{array}$

$\begin{array}{ll}\text { Conclusions } & 80\end{array}$

Conclusion: ConTEXTS: "Doubts and Derisions" 81

Singular Relationship Disrupted 83

Rendering Visible: Presence $\quad 83$

Writing and Representation: Sophie Calle $\quad 84$

Writing and Representation: Paul Auster 84

$\begin{array}{ll}\text { Obedience } & 85\end{array}$

Gaps $\quad 85$

Rendering Visible: Absence $\quad 86$

Knowledge Denied $\quad 86$

$\begin{array}{ll}\text { Entirely Truthful? } & 87\end{array}$

$\begin{array}{ll}\text { Fictions } & 87\end{array}$

$\begin{array}{ll}\text { Storytelling } & 88\end{array}$ 
$\begin{array}{ll}\text { Blurring the Boundaries Even Further } & 87\end{array}$

$\begin{array}{ll}\text { Figures } & 90\end{array}$

$\begin{array}{ll}\text { Bibliography } & 109\end{array}$ 


\section{List of Figures}

Figure 1. Leviathan, Copyright Page. 90

Figure 2. Double Game, Copyright Page. 91

Figure 3. Leviathan, Copyright Page. 92

Figure 4. La Lettre D'Amour, Des Histoires Vraies. 93

Figure 5. Chromatic Diet, Double Game. 93

Figure 6. Suite vénetienne, Double Game. 94

Figure 7. Gotham City, Double Game. 94

Figure 8. The Birthday Ceremony, Double Game. 95

Figure 9. The Wardrobe, Double Game. 96

Figure 10. The Hotel, Double Game. 97

Figure 11. The Striptease, Double Game. 98

Figure 12. The Striptease, Double Game. 98

Figure 13. Letter from Paul Auster to Sophie Calle, Double Game. 99

Figure 14. The Address Book, Double Game. 99

Figure 15. Suite vénetienne, Double Game. 100

Figure 16. Suite vénetienne, Double Game. 100

Figure 17. Pages from Leviathan, Double Game. 101

Figure 18. Pages from Of Grammatology. 102

Figure 19. Gotham Handbook, Double Game. 103

Figure 20. Pages from Leviathan, Double Game. 103

Figure 21 The Detective, Double Game. 104

Figure 22. Days Under the Sign of B, C \& W, Double Game. 104

Figure 23. The Birthday Ceremony, Double Game. 105

Figure 24. The Birthday Ceremony, Double Game. 105

Figure 25. The Birthday Ceremony, Double Game. 106

Figure 26. The Chromatic Diet, Double Game. 106

Figure 27. The Detective, Double Game. 107

Figure 28. Room 44, The Hotel, Double Game. 108 


\section{Introduction: Authorial Turns}

Writing unfolds like a game that 'inevitably' moves beyond its own rules and finally leaves them behind. ${ }^{1}$

Foucault

On the first page of his novel Leviathan (1992), American author Paul Auster thanks French artist Sophie Calle: "The author extends special thanks to Sophie Calle for permission to mingle fact with fiction." (Fig. 1) He "borrows" eight projects from Calle and writes them into his novel as projects created by the artist Maria Turner, a pivotal character in his book. And so we enter the authorial games of Auster and Calle. In return, Calle extends thanks to Auster in her book Double Game (1999): "The author extends special thanks to Paul Auster for permission to mingle fact with fiction. ${ }^{33}$ (Fig. 2)

Calle's Double Game includes the eight projects that Auster borrowed, previously published by Actes Sud: The Wardrobe (1998), The Striptease (1979), To Follow... (1978-79), Suite vénitienne (1980), The Detective (1981), The Hotel (1981), The Address Book (1983) and The Birthday Ceremony (1980-1993). Also included in Double Game, are Calle's adoptions or "borrowings" of two additional projects that Auster authored for his character Maria in Leviathan, also previously published by Actes Sud: The Chromatic Diet (1997) and Days Under the Sign of $B, C \& W(1998)$. The final project, Gotham Handbook (1994), is a project in

\footnotetext{
${ }^{1}$ Michel Foucault, "What is an Author?" in The Art of Art History, ed. Donald Preziosi (New York: Oxford University Press, 1998), 300.

${ }_{2}^{2}$ Paul Auster, Leviathan (London: Penguin Books, 1992), copyright page.

${ }^{3}$ Sophie Calle, with the participation of Paul Auster, Double Game London: Violette Editions, 1999), copyright insert.
} 
which Auster authors Calle: "Auster has taken me as a subject. I imagined swapping roles and taking him as the author of my actions." Double Game is thus divided into three sections: "The Life of Maria and how it influenced the life of Sophie"; "The life of Sophie and how it influenced the life of Maria"; and finally, "One of the many ways of mingling fact and fiction, or how to become a character out of a novel. ${ }^{5}$ Leviathan, Double Game and their intertextuality provides a twisting of tales that makes it difficult to determine fact from fiction and author(s) from subject(s).

Auster's and Calle's reframing of each other's work presents an endless palimpsest where one layer is written/performed upon and over the other, suggesting that one always carries the trace of the other. Double Game already recontextualizes and adapts Calle's and Auster's previous projects. This restructuring is most evident in Calle's addition, of Double Game's "rules": "The Rules of the Game: In his 1992 novel Leviathan, Paul Auster thanks me for having authorized him to mingle fact with fiction. And indeed on pages $60-67$ of his book, he uses a number of episodes from my life to create a fictive character named Maria, who then leaves me to live out her own story. Intrigued by this double, I decided to turn Paul Auster's novel into a game and to make my own particular mixture of reality and fiction." ${ }^{\text {6 }}$ Most of the projects within Double Game are fragments of the larger, previously published projects. Many of the projects

\footnotetext{
${ }^{4}$ Ibid., 234-35.

${ }^{5}$ Ibid., 2-3.

6 Ibid., 1.
} 
have been reordered and redefined. ${ }^{7}$ The repositioning of these projects in Calle's book, I argue, confronts and contests the containment of authorship and the oeuvre.

This thesis examines Double Game and Leviathan, focusing on the moments at which authors and texts intertwine ${ }^{8}$ By exploring literary constructs of authorship and the author's relationship to the text, I concentrate on Auster's and Calle's self-conscious play with their roles of and as 'author' and 'subject'-continually reinventing and repositioning their identity in relation to their fictional narratives. I expose how Calle's and Auster's authorial games disrupt conventional notions of identity as fixed and stable by exploring the possibilities of a shifting plasticity that is always already under erasure. ${ }^{9}$

In Chapter One of this thesis I introduce Calle's Double Game and Auster's Leviathan concentrating on the "mingling" of fact and fiction and the interplay between authors and texts. By weaving fact and fiction and extratextual experiences with textual identity Calle and Auster expose the fiction of identity as

\footnotetext{
${ }^{7}$ Johnny Gratton notes that it is Suite venetienne and L'Hotel that "show changes in textual and photographic content, as well as general layout when compared to the "original' versions." Johnny Gratton, "Experiment and experience in the phototextual projects of Sophie Calle," in Women's Writing in Contemporary France: New Writers, New Literatures in the 1990s, eds. Gill Rye and Michael Worton (Manchester and New York: Manchester University Press, 2002), 161.

${ }^{8}$ In this thesis I will use the word text to refer to all elements of Calle's projects included in her book: the notes, the insertion of the pages from Leviathan, the rules of the game, the images, the journal entries and the stories.

"Like differance, Derrida's "sous-rature" cannot be put into speech (as presence and authority). It is a crossing out of certain words/terms and implies the impossibility of meaning outside metaphysics. This feeds into Derrida's critique of logocentrism in which speech is privileged over writing (as presence).
} 
fixed and unified. Auster's and Calle's texts refute containment and closure crossing the boundaries of fiction, autobiography and even, I argue, autofiction.

Mobilizing poststructuralist theories of authorship, Chapter Two explores the theoretical implications of Double Game and Leviathan's intertextuality and the significance of Calle's and Auster's authorial intrusions. The singularity of the author's relationship to a text is complicated by Auster's borrowing of Calle's projects and Calle's borrowing of Auster's projects--doubly doubled. The movement between author and author/subject enables Calle and Auster to simultaneously construct and deconstruct authorial identity; the absence and presence of the author is always at play, always tentative, ambiguous and fluid. I argue that for both Calle and Auster self-representation becomes a way to challenge, defer and displace their authorial death.

In Chapter Three I situate Calle's and Auster's texts and authorial games within the detective genre and examine Calle's and Auster's strategies of doubling and deferment through metaphors and tropes associated with this genre (a missing person, clues, evidence, gaps, and traces). Identity is shown to be something that can be constructed, deconstructed, manipulated, slipped on and erased. Thus the boundaries of identity become difficult to discern and the reader is forced to investigate and construct meaning through a series of investigative and relational procedures. 
Khimasia, 5

\section{Methodology}

I frame Calle and Auster's exchange through poststructuralist theories, particularly the authorial relationship to a text developed by Barthes and Foucault. In fact, "The Death of the Author" in my thesis exists as a frame within a frame (in keeping with Calle and Auster's exploitation of the mise-en-abyme), in which the metaphor also works for the detective genre in which I situate both Auster and Calle. A Derridean reading of the text has enabled me to explore the collapsing of the binaries of fact and fiction as well as the interplay between author and subject as inside and outside the text. I use Derrida's critique of logocentrism as well as certain concepts such as under erasure, différance, trace and supplement in order to position (and reposition) Calle and Auster's intersections and 'undoings'. I am indebted to Alison Russell's article, “Deconstructing The New York Trilogy. Paul Auster's Anti-Detective Fiction" (1990) for pointing out the overlap between Derrida and Auster's New York Trilogy and Sean Burke's book: The Death and Return of the Author: Criticism and Subjectivity in Barthes, Foucault and Derrida (1992) for his in-depth analysis and working through of the "death [and return] of the author".

To date, there has been no published analysis of Calle and Auster's intertextuality and no close readings of Double Game and/or Leviathan. Paul Auster is widely-known in North America, and Sophie Calle is becoming increasingly well known. Calle's recent retrospective at Centre National d'Art et de Culture Georges Pompidou (2002-3), and her participation in the Venice 
Biennale 2007 has garnered much enthusiasm and press. There have been numerous articles written on Calle (most notably by Bois, Gratton, Camart, Hand, Chadwick, Storr). The catalogue published by the Centre National d'Art et de Culture Georges Pompidou does places her work within the context of French theoretical writing of the 1960's (Lejeune, Ginette, Barthes and Foucault), but there is a lack of analysis and exploration of these theories in relation to her work. Many of the journal articles examine Calle's projects within a psychoanalytic framework, often focusing on desire or her propensity to expose her 'life'. ${ }^{10}$ There is also a tendency in much of the writing about Calle to conflate the author with the subject or "visual persona"; my thesis explores the complications associated with this and looks more closely at the theoretical implications of the represented Calle. Conversely, Auster's work has been written about extensively (particularly The New York Trilogy); however, Leviathan remains under-examined. Arthur Saltzman and Eric Wirth have both written about Leviathan specifically and I incorporate their arguments into my thesis. Writing about Auster, in general, often explores metaphors of the detective and the search for 'self' (Russell, Bernstein, Nealon, Merivale and Sweeny, Chentier). My thesis incorporates these analyses and weaves them into my exploration of Double Game and Leviathan. This thesis deviates from past writing about Calle by looking specifically at the intersections between Auster, Calle and the text; detective metaphors and tropes, postmodern notions of identity and poststructuralist theories of authorship. "Authorial Turns" offers an

\footnotetext{
${ }^{10}$ Most recently in Le Monde, Michel Guerrin described Calle as "une artiste française mondialement célèbre qui a fait de sa vie privée un thème centrale de son oeuvre."Michel Guerrin, "Sophie Calle : De la Douleur Comme un art," Le Monde le 8 juin, 2007.
} 
interdisciplinary analysis of both Double Game and Leviathan and their interwoven quest for identity. 


\section{Chapter 1: Fact and Fiction and the Quest for Identity}

\section{Fact and Fiction: Paul Auster and Leviathan}

On the copyright page of Leviathan, in addition to the thank you to Calle, there is a publisher's note: "This is a work of fiction. Names, characters, places and incidents either are the product of the author's imagination or are used fictitiously, and any resemblance to actual persons, living or dead, events, or locales is entirely coincidental. ${ }^{11}$ (Fig. 3) We, however, also already know that Auster's writing does draw on facts such as Sophie Calle and her projects. So the publisher's disclaimer seems to highlight the self-conscious attempt to make the real fictive, and the fictive real. This publisher's note can be thought of as the epitome--not only of this novel, but Auster's writing in general, and also the work of Calle where fact and fiction collapse into each other.

Auster is known for playing with his role as the 'author' of his work-blending and confusing historical stories and events, writing his name and his life experiences into his novels and drawing attention to the creation and invention of the narrative: the fictionality of the text. ${ }^{12}$ In Leviathan, Peter Aaron, our narrator, is a new writer who has returned to the U.S. from France and makes his living by translating books. Aaron's life echoes Auster's own life: Auster also lived in France and upon returning to America made his living translating books. But as

\footnotetext{
${ }^{11}$ It is important to note that this publisher's note does not appear in any other of Paul Auster's books published by Penguin. Auster, Leviathan, copyright page.

${ }^{12}$ See Auster's The New York Trilogy for the best examples of this.
} 
we have been told in the publisher's note: "... any resemblance to actual persons, living or dead, events, or locales is entirely coincidental."

Leviathan is a quest--for both the identity and the story of an unidentified man who is killed in an explosion (literally fragmented)--a man whom the narrator, Peter Aaron, assumes to be his friend, the writer Benjamin Sachs. It begins with detectives knocking on Aaron's door and ends with these same detectives again at Aaron's door, this time with the 'presumed' identity of the body. While the detectives search for the fragmented body's identity, the events of Sachs' life unfold through the narrative we are reading-the narrative (re)constructed by Aaron. But, the stories we are told and the events that are portrayed are always under question: the characters have different versions of what has happened and the narrator always doubts himself, his memory and his version of the 'truth'. We are continually made aware of the narrator's inability to tell the whole story, even though his goal is to find out what "really happened". Because we are able to see the construction of Sachs' story through differing tales, the narrative voice is always multiple and unreliable. As we begin, Aaron writes: "I don't claim to have more than a partial understanding of who he was. I - want to tell the truth about him, to set down these memories as honestly as I can, but I can't dismiss the possibility that I'm wrong, that the truth is quite different from what I imagine it to be. ${ }^{13}$ Already, there is an obvious tension set up between what is 'truth' and what is 'imagined'; a difference between the event

${ }^{13}$ Auster, Leviathan, 25. 
and the telling, the experience and the narration, the spoken and the written, the facts and the fiction.

Our narrator, Aaron, is in the middle of writing a book about Sachs, who was also in the middle of writing a book when he disappeared. The mise-enabyme (as endless, 'illimitable') becomes a motif in both Calle's and Auster's work. When we, as the reader, discover the intended title for Sachs' book-we are ultimately led back to Auster. Aaron/Auster writes: "To mark what will never exist, I have given my book the same title that Sachs was planning to use for his: Leviathan."14 Leviathan is thus the title for Sachs', Aaron's and Auster's book. Aaron 'borrows' the title from Sachs and Auster 'borrows' the title from Aaron. Yet Auster, as author, has created this fiction and thus written the title of the book into the pages and narration of the story for him to then 'borrow'. The twisted coils of Leviathan bring us back to the beginning and the end. ${ }^{15}$ Auster selfconsciously plays with his role in the construction of this narrative and plants clues that encourage us to acknowledge the fictionality of this novel and question Auster's author-ity in the writing of this text. In Leviathan it is not only the stories themselves that overlap-Auster's story becomes entwined with Aaron's

\footnotetext{
${ }^{14}$ Ibid., 159.

${ }^{15}$ Leviathan has multiple references; it is the large, twisted and coiled sea creature in the Old Testament that I allude to here with no beginning and no end. It is also the title of Thomas Hobbes' book of 1651. Hobbes' Leviathan underscores individuals' social contracts, particularty with the state (Leviathan); and the state's sovereignty or authority over those individuals. Perhaps Auster is playing with his 'authority' over his text--in which the characters are under supposed 'social contracts' with the 'author'. Perhaps Auster uses this reference to deconstruct the "single "theological' meaning (the "message" of the Author-God)". Or perhaps this is another way of referencing what Barthes calls the "Author's empire". Roland Barthes, "The Death of the Author," in The Rustle of Language (Berkley and Los Angeles: University of California Press, 1986), 50 54.
} 
narrative, already a retelling of Sachs' story--but there is slippage between characters (and author(s)) which makes it difficult to determine the boundaries of identity. This blurring of references and tales, "mingling" of fact and fiction denies not only the singularity and fixity of identity, but also a unitary and fixed meaning: the "single 'theological' meaning".

\section{Fact and Fiction: Sophie Calle and Double Game}

Just as Auster uses a writer writing as the main substitution (and displacement) for telling the story, so Calle's photographs and first-person narratives of her 'experiences' become entangled in a series of displacements and supplements of "Sophie Calle" making it difficult to determine and define the edges of her roles as author and subject. Calle not only disrupts the binaries of author/subject and fact/fiction, but also explores the materiality and temporality of identity in such a way that it is always ambiguous.

In the photographic and written work of Calle it is difficult to determine what is fact and what is fiction, complicated by her diaristic narratives and constructed documentation. She is always telling stories, ${ }^{16}$ most notably seen in Des Histoires Vraies ${ }^{17}$ (1994), not included in Double Game; in this project/book she gives us seemingly important stories from her life accompanied by 'illustrative' photographs (as evidence or trace). It is impossible to know if these

\footnotetext{
${ }^{16}$ It is Hervé Guibert's who first labeled Calle a "faiseuse d'histoires". "Les Tribulations de Sophie Calle en enfance," Le Monde, Arts et Spectacles, jeudi le 16 août 1984.

${ }^{17}$ Des Histoires Vraies when translated into English is titled Autobiographical Stories--another way in which Calle challenges the boundaries of truth and fiction.
} 
stories are fictional or true: "For years a love letter languished on my desk. I had never received a love letter, so I paid a public scribe to write one. A week later, I received seven beautiful pages of pure poetry penned in ink. It had cost me one hundred francs and the man said: '... without moving from my chair I went everywhere with you. ${ }^{m 18}$ This is accompanied by a black and white photograph of an illegible, hand-written letter. (Fig. 4) In Leviathan, Maria (the artist for whom Auster borrows Calle's work) remembers Sachs, reflecting on her work: "He understood that all my pieces were stories, and even if they were true stories, they were also invented. ${ }^{19}$

Calle's constructions encourage the reader to attempt to determine fact from fiction, but Calle's self-conscious blurring of fact and fiction suggests that any attempt will prove futile. In an interview with Lawrence Rinder, Calle states, "... in most of my work there is one lie. For example, in The Hotel series, in which I photographed people's rooms--all the rooms are perfectly right, there is nothing that I add, nothing I lie about. But there is one room that is completely fake. It's a room I would have liked to have liked to find [sic] and didn't. I put my fantasy inside. In The Blind [not included in Double Game] there is one whose answer I gave myself. ${ }^{20}$ In Calle's documents and testimonies we are never able to distinguish fact from fiction.

\footnotetext{
${ }^{18}$ Sophie Calle, Des Histoires Vraies (France: Actes Sud, 1994), 25. English translation from "Appointment with Sigmund Freud," Sophie Calle, M'as-tu vue, ed. Christine Macel (Paris: Centre National d'Art et de Culture Georges Pompidou, 2003), pages unnumbered.

${ }_{19}^{10}$ Auster, Leviathan, 143.

${ }^{20}$ Lawrence Rinder, "A Conversation with Sophie Calle, " CALENDAR, (Berkeley: University Art Museum, 1990) unpaginated.
} 
Yet, when reading Calle's 'narratives' we do begin to constitute an identity for Calle but we are also always deconstructing "Sophie Calle"; for there is no unified identity--it is always uncertain--continually under construction. Her work is fragmentary, like the stories that Aaron, in Leviathan, pieces together creating the identity and story of Sachs. By looking at a number of Calle's works we see that images are recycled, references rewoven, tales retold--the fragments are highlighted--exposing both the fabrications and the fictions of her individual narratives. But Calle presents her work as 'fact', in her detective-like manner she recites dates, times, places as though there is no doubt about her narrative, however on closer inspection there are gaps, things that contradict each other: something that always allows the narrative to come unraveled, something that makes us doubt the 'truth' of her tales.

Double Game consists of Calle's projects, Auster's projects written for Maria, and Gotham Handbook in which Auster authors Calle. Divided into three sections, each project begins with "la règle du jeu" in which Calle explains what she is doing: the rules of the game and/or the task she has given herself. This is followed by a collection of photographs and texts, each project is different and arranged and positioned slightly differently on the page. The texts range from clinical lists and objective descriptions to emotional and subjective comments on 
the events as they happen. ${ }^{21}$ Calle's photographs are also very different from each other. In The Chromatic Diet the images are in colour, carefully framed, in focus, each one like the previous one--almost clinical. (Fig. 5) In contrast, the photographs in Suite vénetienne have the look of surveillance images: black and white, grainy, out of focus, poorly framed. (Fig. 6) In fact, Yves-Alain Bois suggests that Calle's adoption of Auster's projects announce their artificiality in two ways: through her disobedience ${ }^{22}$ and through the photographs which in Chromatic Diet and Days Under the Sign of $B, C \& W$, "are much too neat to be genuine Calle....The photos of Gotham Handbook... by contrast, are pure Calle (people shot from the back, the framing is slapdash, the scale inconsistent, etc.)". ${ }^{23}$ (Fig. 7) While I agree that Calle's photographs are not coherent and unified in their aesthetics, 1 argue that they exist as different forms of document and contrary to Bois's analysis, there are projects that are not authored by Auster that have the same clinical, well-composed, well-framed, "too neat" composition, for example, The Birthday Ceremony, The Wardrobe and even The Hotel. (Fig. 8-10) According to Chris McAuliffe, Calle's photographs, "claim a transparent visual meaning when used to document inquiries; they claim the status of truth and evidence when used as part of a detective investigation; they claim a

\footnotetext{
${ }^{21}$ Time in Calle's work oscillates between the past and the present, perhaps playing with Barthes" assessment that "every text is written in the eternally here and now." Roland Barthes, "Death of the Author," 52.

${ }^{22}$ I argue, in ChapterTwo, that Calle's disobedience is indeed a challenge to the authority of the author and a reinscription of her place in the process--in the performance--rather than an explicit announcement of the its 'fakeness'. Bois suggests that Calle, like God, renounces The Chromatic Diet on the seventh day. Is there a link here with Barthes "Author-God"? Yves-Alain Bois, "Paper Tigress," October, 116 (Spring 2006):45.

${ }^{23}$ Ibid.
} 
disingenuous sincerity when documenting people's favourite things...." ${ }^{24}$ But her photographs also allow us to see the constructions by exposing the slippage between the textual and the visual, the moments at which the photograph and the text do not conform.

For example, in The Striptease, included in Double Game and also retold with slightly different 'facts' in Des Histoires Vrais (2003), ${ }^{25}$ we are led to believe that we are encountering a story connected to Calle's past: "I was six. I lived on a street named Rosa Bonheur with my grandparents. A daily ritual obliged me every evening to undress completely in the elevator on my way up to the sixth floor, where I would arrive without a stitch on. Then I would dash down the corridor at lightning speed, and as soon as I reached the apartment, jump into bed. Twenty years later, in 1979, I found myself repeating this ritual every night in public, on the stage of one of the strip joints that line the boulevard in Pigalle, wearing a blonde wig in case my grandparents, who lived in the neighbourhood, should happen to pass by." ${ }^{26}$ (Fig. 11) The blonde wig, also seen in Suite vénetienne, is often a stand-in or sign for Calle's performative self; it is connected to disguise and the hiding of self--it is both self and not self. The 'telling' of this incident also works like a palimpsest where the event is now informed and

\footnotetext{
${ }^{24}$ Chris McAuliffe, "It's Okay, I'm an Artist: Sophie Calle's Photographs," in Binocular: Focusing, Writing, Vision, eds. Ewen McDonald and Juliana Engberg (France: Moët and Chandon Contemporary Edition, 1991), 33-34.

${ }^{25}$ In Des Histoires Vraies this story is actually two stories entitled: "Le strip-tease" and "Le Talon Aguille." In "Le Talon Aguille" the 'facts' are slightly different: "Engagé comme strip-teaseuse dans une baroque foraine installée pour les fêtes de Noël au carrefour du boulevard de Clichy et de la rue des Martyrs, je devais me déshabiller dix-huit fois par jour entre seize heures et une heure du matin. Le 8 janvier...." Calle, Des Histoires Vraies, 21.

${ }^{26}$ Calle, The Striptease, Double Game, 44-45.
} 
remembered through her more recent story of the striptease. Fact and fiction are again provocatively blurred--did Calle indeed perform this ritual as a child? Did she actually perform the striptease? We presume her Pigalle performance to be 'true' since her book contains photographs of the striptease. The linking of this story to a story, supposedly from her past, helps draw attention to the construction of this particular narrative. The last image in The Striptease, (Fig. 12) a black and white image of Calle crumpled on the floor, is accompanied by text that reads: "On January 8,1981 , as I was sitting in the only chair in my trailer, one of my colleagues, to whom I refused to give my seat, tried to poke my eyes out with her high heel and ended up kicking me in the head. I lost consciousness. During the fight she had, as the ultimate stage of stripping, torn off my blonde wig. This was to be my last performance in the profession. ${ }^{27}$ The constitution of this story is transparent; the photographic documentation both authenticates the performance while also denying it: could this have happened while someone was taking photographs? The removal of the wig leads us back to Sophie Calle, the author and narrator of these stories-through Sophie Calle the performer of these tales. Like Aaron in Leviathan, Calle draws attention to the gaps and fragments--her telling does not allow for a coherent, unified and 'truthful', telling of her experience. Almost Brechtian in its presentation, The Striptease and the other projects in Double Game abruptly disturb the narrative from being completely absorbed, believed and/or convincing. Calle's identity as the subject of her narratives is seen as fluid and the process, construction and production of this identity is cleverly exposed. In Calle's work the boundaries

\footnotetext{
${ }^{27}$ Ibid., 67.
} 
between real/fictive, public/private, presence/absence as well as subject/author are often confused and blurred. Representation is always under erasure for the ambiguity of the subject and its referent is a/ways already tentative. Text and photograph, as document of the truth, are always questioned.

While Auster's narrator searches for Sachs' identity through telling and listening to stories about Sachs, Calle's projects present "une enquête" for Calle ${ }^{28}$ Her texts are clinical and categorical-like the notebook of the detective looking for clues. As Johnnie Gratton asks: "What does it mean to be 'implicated in' one's own work, as opposed to, say being 'expressed by' it?"29 Metaphors of policing and surveillance run through Calle's work--the quest for an ever-elusive identity of both artist and her 'double'. Gratton links her work to ideas of "experimental individualism" (rather than "possessive individualism") where the self is continually assembled and disassembled. ${ }^{30}$ The experiment, or the process, is to see what happens to the self as one watches it come into view as the other. ${ }^{31}$ Calle's interplay between document and fiction, experience and experiment, public and private allows us as the reader and viewer to be involved in the process, putting the clues together to see who is implicated--but the suspect is always changing.

\footnotetext{
${ }^{28}$ Gratton actual refers to it as a "pseudo-enquête". Johnnie Gratton, "Experiment and Experience in the Work of Sophie Calle," 158.

${ }^{29}$ Ibid., 157.

${ }^{30}$ Ibid., 158.

${ }^{31}$ I actually think that Calle and Auster also disrupt the binary of Self/Other which I would discuss in a longer paper. Ibid., 158.
} 


\section{Representation: Truth, Fiction, and Autobiography: PA}

We are told on the copyright page of Leviathan that this is a work of fiction, but the overlap with the autobiographical elements of Auster's life cross the boundaries between fiction and autobiography that Phillipe Lejeune has tried to define. For Lejeune, autobiography is: "Retrospective prose narrative written by a real person concerning his own existence, where the focus is his individual life, in particular the story of his personality." 32 But Leviathan does not conform to the rules of autobiography (for example the name of the protagonist and the author should be the same); but Peter Aaron is "a writer whose career suspiciously reflects and refracts Paul Auster's own." ${ }^{33}$ These reflections and refractions suggest that for Auster, as author, there is no unitary, fixed or essential self. Similarly, in Auster's novels, detecting a singular identity becomes difficult amidst the "forged papers and empty names." 34 According to Dennis Barone, Auster's shifting subjectivities, which contain not only references to his own life but to other literature and actual historic figures and events, do not disrupt the reading, but indeed point to the works' fictionality. ${ }^{35}$ This is also evident in the conflicting stories that we encounter in the narrative, the gaps (in the telling of the story) that have been filled in (invented) by Aaron: "I wrote a

\footnotetext{
32 Philippe Lejeune, On Autobiography (Minneapolis: University of Minneapolis, 1989), 5.

${ }^{33}$ Arthur Saltzman, "Post Hoc Harmonies: Paul Auster's Leviathan," In This Mad Instead: Governing Metaphors in Contemporary American Fiction (South Carolina: University of South Carolina Press, 2000), 63.

${ }^{34}$ Patricia Merivale and Susan Elizabeth Sweeny. "The Game's A Foot: On the Trail of the Metaphysical Detective Story," In Detecting Texts: The Metaphysical Detective Story from Poe to Postmodernism (Philadelphia, Pennsylvania: Pennsylvania Press, 1999), 10.

${ }^{35}$ Dennis Barone, "Introduction: Paul Auster and the Post Modern American Novel," In Beyond the Red Notebook: Essays on Paul Auster (Philadelphia: University of Pennsylvania Press, 1995) 5.
} 
short, preliminary draft in the first month, sticking only to the bare essentials. When the case was still unsolved at that point, I went back to the beginning and started filling in the gaps.... ${ }^{n 6}$ Aaron in the act of writing is a way in which Auster draws attention to both the fictionality of this narrative and also his role in the creation of this fiction. The interplay between fact and fiction is also reiterated in and through Sachs' novel: "Sachs loved these ironies, the vast follies and contradictions of history, the way in which facts were constantly turning themselves on their head. By gorging himself on these facts, he was able to read the world as thought it were a work of the imagination turning documented events into literary symbols, tropes that pointed to some dark, complex pattern embedded in the real. I could never be quite sure how seriously he took this game, but he played it often, and at times it was almost as if he were unable to stop himself. ${ }^{\prime 37}$ This, like many of the statements in Leviathan, is ambiguous in its implied relationship to the text we are now reading.

According to Wolfgang Iser, indications of fictionality are a "basic attribute of fiction, but should a fiction fail to self-disclose of its own accord-it has to be unmasked. ${ }^{238}$ This "self-disclosure" puts the represented world in brackets. ${ }^{39}$ But for authorial Auster and Calle and for "Auster" and "Calle" represented, already within brackets, we become unsure of where the brackets start and stop. For Calle performing Maria performing Calle performing "Calle" makes it difficult to

\footnotetext{
${ }^{36}$ Auster, Leviathan, 273.

${ }^{37}$ Ibid., 27.

${ }^{38}$ Wolfgang Iser, "Feigning in Fiction," in Jdentity of the Literary Text, ed. Mario J. Valdes and Owen Miller (Toronto, Buffalo, London: University of Toronto Press, 1985), 216.

${ }^{39}$ Ibid., 217.
} 
distinguish where one stops and the other begins; they always carry the trace of the other. Who is represented?

Aaron writes: "If not for the breakup of my marriage to Delia Bond, I never would have met Maria Turner, and if I hadn't met Maria Turner, I wouldn't have known about Lillian Stern, and if I hadn't known about Lillian Stern, I wouldn't be sitting here writing this book. Each one of us is connected to Sachs's death in some way, and it won't be possible to tell his story without telling each of our stories at the same time. Everything is connected to everything else, every story overlaps with every other story. ${ }^{40}$ For both Calle and Auster "telling stories" that "overlap with other stories", the fictionalization of authorial experiences and the 'mingling' of fact and fiction becomes a strategy for constructing and simultaneously deconstructing identity. For if identity is created through story telling, not only the stories that we tell about the self but the stories that other people tell, then Calle and Auster are both successful in displacing identity from its fixed and central position to the margins and outside, allowing for multiple positions, voices and narratives. The fragmentary nature of their tales and visuals do not allow for a single unified identity; there are always gaps and contradictions.

\section{Representation: Truth, Fiction and Autofiction: SC}

In contrast to Auster's self-declared work of "fiction", Calle's work is often described as autofiction: "works through which authors create new personalities and identities for themselves, while at the same time maintaining their identity

\footnotetext{
${ }^{40}$ Auster, Leviathan, 57.
} 
(their real name). ${ }^{, 41}$ There is a double-writing that is associated with autofiction which never allows the reader to "identify the real from the fictional at the level of enunciation." ${ }^{42}$ I agree that Calle (and Auster) present their work in such a way that the binary of real and fictional collapses or folds in on itself. Olivier Asselin and Johanne Lamoureux also argue that in autofiction it is the self that indeed becomes a motif. ${ }^{43}$ While Auster and Calle do play with constructions of self, I argue that Auster and Calle's intertextuality also complicates notions of self and autofiction-for in performing Maria's projects (Chromatic Diet and Days Under the Sign of $B, C \& W$ ) or becoming the "subject" by following Auster's authorial "instructions" (Gotham Handbook) the roles between Auster and Calle also become increasingly blurred as authors, texts and narrators also collapse into each other and it is difficult to discern the boundaries between Auster/Calle/Maria/Aaron and their respective roles and experiences.

In Gotham Handbook, the final project in Double Game, Calle asked Auster to invent a character that she would try to resemble. "...Auster objected that he did not want to take responsibility for what might happen when I acted out the script he had created for me. He preferred to send me "Personal Instructions

\footnotetext{
${ }^{41}$ Olivier Asselin and Johanne Lamoureux. "Autofictions, or Elective Identities," Parachute, no. 105 (January - March 2002): 11.

${ }^{42}$ Marion Sadoux, "Christine Angot's autofictions: literature and/or reality?" in Womens Writing in Contemporary France, eds Gill Rye and Michael Worton, (Manchester and New York: Manchester University Press, 2002), 176.

${ }^{43}$ Asselin and Lamoureux, "Autofictions, or Elective Identities," 11.
} 
for SC on How to Improve Life in New York (Because she asked...). I followed his directives. This project is entitled Gotham Handbook." ${ }^{44}$ In his note to Calle, also included in Double Game, Auster writes: "I wanted to leave it open enough so that you could find your own way through the ideas. ${ }^{.45}$ (Fig. 13) Through Calle's engagement with the text--the breaking open of the text--the gaps are revealed. Auster writes Calle instructions that fall under four categories: "Smiling, Talking to Strangers, Beggars and Homeless People" (and how she must interact with them) and "Cultivating a Spot". Calle chose to look after a phone booth at the corner of Harrison and Greenwich Streets in New York City. Everyday on her way to the booth where she provided postcards, a mirror, an ashtray, flowers and a chair, Calle handed out sandwiches, cigarettes and smiles to the anonymous people that she passed. The focus of this performance is about identity againher anonymity, her position as subject to Auster as author and the anonymity of the strangers she passes. Her identity, once again, shifts as she assumes a new role performing Auster's writing. In Gotham Handbook Calle oscillates between being bound by Auster's instructions and interjecting her own author-ity. Calle feels she has "a duty to obey. That was the agreement. I have no other choice but to submit [to Auster's words]. ${ }^{n 46}$ But, in the very next paragraph, Calle also exposes Auster's gaps and fills them in: "Paul didn't ask me to count the smiles I give. Unquestionably an oversight. I add this item to the handbook. ${ }^{47}$ Calle continues to play with her relationship to the author-ity of Auster's instructions: "I

\footnotetext{
${ }^{44}$ Calle, Gotham Handbook, Double Game, 234 -235.

45 Ibid., 237.

${ }^{46}$ Ibid., 246

${ }^{47}$ Ibid.
} 
have a fantasy: I am arrested [for tapping a public phone], I stand before the judge. He proposes an alternative punishment: smile, distribute food, and talk to people. I say: 'No! I prefer jail." 48

\section{(De)Constructing Identity}

We see Calle's (de)construction of identity through multiple voices and conflicting stories more explicitly in The Address Book. In 1983, Calle discovered an address book on the street and then contacted the people whose names were listed in the book and questioned them about the owner of the address book; these 'observations' and stories, gathered by Calle, were then published in the French newspaper, Libération, without revealing the identity of the owner. Calle's goal here was to "get to know this man through his friends, his acquaintances." 49 The anonymity of the man was upheld while stories, secrets and tales were divulged in public constructing an identity for the man who owned this book. The Address Book consists of three main sections. The first section, opposite a photograph of the/a address book, (Fig. 14) explains the facts: "There were 408 names, distributed as follows: $25 \mathrm{~A}, 63 \mathrm{~B} \ldots{ }^{.50}$ This is followed by a long and varied description of Pierre D. (the owner (and subject) of the address book) who: "...loves minor literature, B-movies, nineteenth century potboilers, and opera; a pinball wizard, who looks out of place in a nightclub, who wears sagging clothing... someone who could be capable of disappearing without trace. ${ }^{.51}$ This is the last sentence in the description. Again we see Calle's obsession with the

\footnotetext{
48 Ibid., 252.

${ }^{49}$ Calle, The Address Book, Double Game, 186-187.

${ }^{50}$ Ibid., 189.

${ }^{51}$ Ibid., 191.
} 
disappeared body, the absent subject..$^{52}$ The last section of this project contains Calle's comments: "I could almost say that I knew him well. I had left my home to move into a more anonymous place so I could immerse myself more radically in his life and habits. ${ }^{153}$ Upon his return, when Pierre D. found his life had been exploited in the newspaper, he retaliated by reversing the scenario and had the newspaper publish a naked photograph of Calle. The Address Book in Double Game therefore also contains a disclaimer regarding "privacy" and "inflammatory" comments taken "from the Author's contract with Violette Editions." ${ }^{54}$ The "full story of the address book is missing from this publication." ${ }^{55}$ The gaps are again highlighted.

Before Calle 'found' the address book she had already agreed to do a serial project ("feuilleton") for the newspaper. Again, we question the 'truth': was there really an address book? Does Pierre D. exist? How does her construction of Pierre D. differ from her constructions of "Sophie Calle"? This project is also borrowed by Maria in Leviathan; it is through the address book that Maria is reunited with Lillian, with whom she briefly switches identities. Aaron suggests that it is indeed Maria's finding of the address book that started the events in motion, the events of the book we are reading: "... she went out one morning to

\footnotetext{
52 I can't help but draw the connection... "Thus on September 2, I ended the interview with Jacques D. [Derrida?] with the words: "I wonder if he knows about this yet, if he'll be angry with me. Perhaps he'll never know." Interestingly enough the cover of the Address Book has a red line through it- like Calle's writing on Auster's pages and/or Derrida's use of the line to place something under erasure. Is Calle placing the concept, Pierre D.'s identity, the narrative or the unpublished transcripts under erasure? Ibid., 192.

${ }^{53}$ Ibid.

${ }^{54}$ Ibid.

${ }^{55}$ Note that the "full story" is also missing from the 'original' publication: Le carnet d'adresses (France: Actes Sud, 1998).
} 
buy film for her camera, saw the little black address book lying on the ground, and picked it up. That was the event that started the whole damn miserable story. Maria opened the book and out flew the devil. ${ }^{.56}$ Events happen by chance; it is the narration of these events, the fictionalization of these events that help create the narrative--the narrative that enables us to construct identities.

Anonymity, or the subject's unknown identity, comes up repeatedly in Calle's work. In Suite vénitienne, Calle is introduced to a man whom she had "followed" earlier in the day, and decides to follow him to Venice: "That very evening, quite by chance, he was introduced to me at an opening. During the course of our conversation, he told me he was planning an imminent trip to Venice, I decided to follow him." ${ }^{57}$ In this project Calle plays with her own anonymity, again wearing her blonde wig as 'disguise'. In her detective-like manner, Calle takes black and white photographs of Henri B. and his movements around Venice, noting times and events in her 'notebook'. We not only have black and white photographs of Henri B. walking down the lanes and alleys, (Fig. 15) but also photographs of things he has seen, places he has been: "Ponte della Madonnetta--he crouches to snap a shot of the canal, or perhaps of that passing boat? After several seconds, I imitate him, trying my best to take the same picture. ${ }^{n 58}$ (Fig. 16) But again the 'game' is disrupted, the rules broken and her

\footnotetext{
${ }^{56}$ Auster, Leviathan, 73.

${ }^{57}$ Calle, Suite vénetienne, Double Game, 76-77.

58 Ibid., 95.
} 
identity discovered when she is confronted by her own subject (Henri B.): "I recognize your eyes; that's what you should have hidden." ${ }^{59}$

When Suite vénitienne was first published, it included an essay by Jean Baudrillard entitled "Please Follow Me." In his essay, Baudrillard suggests that following or doubling is another way to distance you from yourself: "You exist only in the trace of the other, but without his being aware of it; in fact you follow your own tracks almost without knowing it yourself. ${ }^{n 60}$ In "Please Follow Me", included in the 'original' printing of Suite vénetienne, Baudrillard argues that, "It is shadowing itself that gives the other's double life. To shadow another is to give him, in fact, a double life, a parallel existence." ${ }^{\text {61 }}$ This can be applied to Calle, Maria, Auster, Aaron and Sachs and the intricate relationships and tensions that are created. Baudrillard continues, "Simultaneously, she who follows is herself relieved responsibility for her own life as she follows blindly in the footsteps of the other. Again, a wonderful reciprocity exists in the cancellation of each existence, in the cancellation of each subject's tenuous position as a subject. ${ }^{n 2}$ Calle, Maria, Auster, Aaron and Sachs as subject are also the absent subject--the sign without referent.

But Calle and Auster consciously draw attention to, reiterate and remark their positions as both author and subject. Included in the first few pages of Double Game are pages 60-67 of Leviathan (Faber and Faber edition): the

\footnotetext{
${ }^{59}$ Ibid., 106.

${ }^{60}$ Jean Baudrillard, "Please Follow Me," in Suite vénitienne (Seattle: Bay Press. 1988), 76.

${ }^{61}$ ibid., 79

${ }^{62}$ ibid., 82.
} 
pages describe Maria/Calle's projects. Calle 'edits' these printed pages, reclaiming her experiences and playing with ideas of authorship and the palimpsest. She begins by writing "Hello Maria" across the first page with red ink and then proceeds to "correct" Auster's telling--reclaiming her narrative. (Fig. 17) "The next morning, week, she caught a flight train from La Guardia Paris to New Orleans Venice, checked into a hotel, and bought herself a black blonde wig." The authorial voice is explicitly multiple, her comments written over the 'original' printed words that were "borrowed" from her own project; the doubling voice has an echo. Like the red lines traced through the cover of The Address Book, the red lines through the words here reflect Derrida's strategy of putting a word or a concept under erasure--a line through the original; but still enabling it to be read: it is both and neither. (Fig. 18) Calle reinscribes her authorial ability and experiences which appear to be inextricably bound to 'facts' which then serve to highlight Auster's fictionality.

\section{Conclusion}

Both Calle and Auster displace and complicate the singularity of the relationship between author/text and fiction/truth. Meaning is thus not produced through a static closure of the binary but through continual oscillation and movement between and outside. According to David Lodge, "Instead of trying desperately to defend the notion that the individual utterances of texts have a fixed, original meaning which it is the business of criticism to recover, we can locate meaning in the dialogic process of interaction between speaking subjects, 
between texts and readers, and between texts themselves. "63 By mingling fact with fiction and authorship, Calle and Auster, also develop dialogic relationships between the authors, narrators, texts and performances. This 'folding-over' and collapsing of different subject positions repositions and replaces identity, no longer conceived of as original, unique and reducible, with a new plasticity, where identity may be chosen, constructed, acquired and planted. By making us aware of the constructions; by exposing the fictionality of these stories; by exploiting the endless possibilities and (re)constitutions of this new materiality; and through an interplay of palimpsestuous textual relationships, Calle and Auster explore the fiction of identity as fixed, essential and complete. Identity, and particularly the identity of Auster and Calle (and their stand-ins), is always fluid, repositioning and (re)presenting self both inside and outside their texts through an interplay of fact and fiction. L'enquête de Sophie Calle continura; and maybe this time, Paul Auster is suspect.

${ }^{63}$ David Lodge, After Bakhtin: Essays on Fiction and Criticism (London and New York: Routledge, 1990), 86. 


\section{Chapter 2: Authorial Intrusions: the Presence of the Absent Referent.}

Every time Sachs posed for a picture he was forced to impersonate himself, to play the game of pretending to be who he was. ${ }^{64}$

Aaron/Auster

\section{Author/Text Interrupted}

Calle and Auster's movement between author and author/subject exposes not only the arbitrary nature of sign/signified/referent, but also this movement confronts us with the play of authorial presence and absence. For in challenging the 'singular' relationship that holds between an author and text, Calle and Auster disrupt conventions of authorial origin and authority. Calle's and Auster's refusal to submit to their Barthesian "death" demands that we reconsider writing, authorship and the already deconstructed positions of subject and author.

In "What is an Author?" Foucault attempts to define (and "restrict") authorship and "the singular relationship that holds between an author and a text. ${ }^{65}$ Assigning a number of author-functions to the text/author relationship, Foucault positions the author somewhere between obliteration and collective subjectivity, suggesting that the confrontations that an author "generates between himself and his text cancel out the signs of his particular individuality. ${ }^{n 66}$ By removing the signs, or traces, of the individual author the text is then

\footnotetext{
${ }^{64}$ Auster, Leviathan, 145.

${ }^{65}$ Foucault, "What is an Author?", 300.

${ }^{66}$ Ibid., 301.
} 
transformed; and the author, through his/her absence, becomes a victim of his/her own writing.

For Barthes, the singularity of the relationship between the text and its author is wrapped up in the "Author-God"--the "single 'theological' meaning", and what Barthes describes as the point of origin. In order to disrupt this singular and original relationship Barthes proposes the "death of the author", and connects this authorial disappearance to a loss of origin: "As soon as a fact is narrated... the voice loses origin, the author enters into his own death, writing begins. ${ }^{67}$ For Barthes, "writing is the destruction of every voice, every origin. Writing is that neuter, that composite, that obliquity into which our subject flees, the black and white where all identity is lost, beginning with the very identity of the body that writes." ${ }^{.68}$

But Auster's and Calle's authorial games elaborately weave, blend and plant real experiences and names in their texts which cause us to still seek out the author, "the figure who is outside and precedes" the text. ${ }^{69}$ Aaron/Auster and Calle-represented become not only the sign of the author, but also, I argue, a sign of their absence (death), for the signifiers of "Paul Auster" and "Sophie Calle" become blurred and confused with their referent yet also liberated from the

\footnotetext{
${ }^{67}$ Barthes, "Death of the Author," 49.

68 Ibid. , 49.

${ }^{69}$ Foucault, "What is an Author?", 300.
} 
confinement, fixity and obsession with presence usually associated with sign/signifier/signified. ${ }^{70}$

For if the sign denotes what is absent, it, according to Derrida, is already the break in the homogeneity of the system. ${ }^{71}$ But it is not a stand-in or replacement for the object/subject itself for "Every sign, linguistic or nonlinguistic, spoken or written (in the current sense of this opposition) in a small or large unit can be cited, put between quotation marks; in so doing it can break with every given context, engendering an infinity of new contexts in a manner which is absolutely illimitable. ${ }^{n 72}$ This arbitrariness and 'illimitability' of the sign allows for free-play of the signifier which both Auster and Calle explore and exploit. The deconstruction of author-ity, moment of origin and fixity of the sign and its signified is played out through oscillation and shifting between "Sophie Calle" and "Paul Auster" as author(s) and subject(s).

The intertextuality in and between Double Game and Leviathan provides continual transformations in representation. Through Calle's and Auster's shifting subjectivity and their movement between texts as both author (outside the text) and subject (representation in the text) they are able to expose, not only the fictionality of both 'author' and 'subject', but also the structure of representation

\footnotetext{
${ }^{70}$ Derrida writes, "According to classical semiology, the substitution of the sign for the thing itself is both secondary and provisional: secondary due to an original and lost presence from which the sign thus derives; provisional as concerns this final and missing presence toward which the sign in this sense is a movement in mediation." Jacques Derrida, "Différance," in Margins of Philosophy (Chicago: University of Chicago Press, 1982), 9. 71 Jacques Derrida, "Signature Event Context," in Margins of Philosophy (Chicago: University of Chicago Press, 1982) 4.

${ }^{72}$ Ibid., 12.
} 
itself. Through the inability to determine fact from fiction and author from subject the instability of the text is exposed creating a web of infinite possibilities that debunk notions of authorial origin, and truth--the referent is dissolved between these intertextual layers of representation. Roland Barthes writes:

Do I not know that, in the field of the subject, there is no referent? The fact (whether biographical or textual) is abolished in the signifier, because it immediately coincides with it: writing myself... I myself am my own symbol, I am the story which happens to me: freewheeling in language, I have nothing to compare myself to; and in this movement, the pronoun of the imaginary, "I" is impertinent, the symbolic becomes literally immediate: essential danger for the life of the subject: to write oneself may seem a pretentious idea; but it is a simple one: simple as the idea of suicide. ${ }^{73}$

By destabilizing their own authorial identity as unified and unitary Calle and Auster transform their writing into an interplay of signs. "Sophie Calle", like "Paul Auster", as both author and subject of Calle's work continually slips between, and outside, the role of signifier and signified. The movement between Auster and Calle and Calle and Auster enables difference to be articulated. Meaning is no longer produced through the closure of signifier and signified but rather through the free-play of the signifier. Calle and Auster deconstruct and expose the arbitrary linkage of signifier and signified. What do "Sophie Calle" and "Paul Auster" signify? Is "Sophie Calle" within the frame or the text a sign for Sophie Calle outside the frame or the text? Is Peter Aaron merely a textual recreation of Paul Auster? "Sophie Calle" and Paul Auster" as both sign and signifier are constructed and deconstructed simultaneously. This unstable

\footnotetext{
${ }^{73}$ Roland Barthes, Roland Barthes by Roland Barthes (New York: Hill and Wang, 1977), 56.
} 
signification is articulated through the "mingling" of fact and fiction and its relation to narration and representation. For example, on the last page of Gotham Handbook (the project in which Auster authors Calle) there is a photograph of Calle in front of the telephone booth. (Fig. 19) The text beside the image reads: "That same evening I have dinner with Paul Auster. I inform him that I have put an end to Gotham Handbook. Maybe I am still wearing that contrived smile during the evening because at one point Paul leans over to me, speaking softly as if at a patient's bedside: 'It's over, Sophie. ... It's over. You can stop smiling now. ${ }^{m 74}$ Fact /fiction, public/private, and author/subject are provocatively blurred as the boundaries between authorial Paul Auster and Sophie Calle and represented Paul Auster and Sophie Calle are completely eroded--endless layerings of fictions and facts.

\section{Authorial Identity}

Foucault argues that the name of an author has an ambiguous function; an ambiguity that is played out in Calle's and Auster's work. For both Calle and Auster, and their "double" (or triplet as I argue in Chapter Three), work against the grain creating a more elusive identity that is at once multiple, incongruous, false yet convincing. The multiplicity of their position as writer and subject in their work allows for fluidity between and outside. Auster's borrowing of Calle's projects and then Calle's borrowing of Auster's writing not only interrupts and complicates any "singular relationship" but enables 'illimitability' as Auster is able to move between his own experiences, his fictions, and Calle's projects. And

\footnotetext{
${ }^{74}$ Calle, Gotham Handbook, Double Game, 292-293.
} 
similarly, Calle's relationships become multiple as she also oscillates between author, subject, performer and, ultimately, reader of these texts. Therefore, for both Auster and Calle the singularity of the authorial relationship with the text is multiplied through authorial imposition in their work, and also complicated by their intrusion into each others' work.

For the proper name of the author is an "improper variation on the common name; we locate a body of texts arbitrarily assembled under the signature 'Rousseau', but we do so on the understanding that the name 'Rousseau' is under erasure throughout, that, strictly speaking, it has no meaning, signifies absence." "Calle" and "Auster" operate in the same way; we refer to "Calle" as both author and subject as if they are indeed the same; but they function in different ways and "Calle" (like "Auster") is always under erasure.

Writing of Paul Auster's New York Trilogy, Alison Russell proposes that, "If these novels [City of Glass, Ghosts, The Locked Room] are linguistic constructs of the author, Paul Auster, their protagonists' quests for an ultimate authority and identity serve as ironic frames for the author's own logocentric quests for origin, a quest for himself that he continually deconstructs. ${ }^{176}$ Russell suggests that Auster's writing is indeed a deferment of the "death of the author," Auster both inside and outside the text is always fighting for the upper hand in

\footnotetext{
${ }^{75}$ Sean Burke, The Death and Return of the Author: Criticism and Subjectivity in Barthes, Foucault and Derrida, 121.

${ }^{76}$ Alison Russell, "Deconstructing The New York Trilogy: Paul Auster's Anti-Detective Fiction," Critique volume 31, Issue 2 (Winter 1990): 80.

${ }^{77}$ Ibid.
} 
Derrida's "violent hierarchy. ${ }^{n 78}$ It is this oscillation, the ceaseless undoing, the "both/and" that denies any kind of hierarchy in Leviathan.

Foucault suggests that writing has been transformed by our culture; from a written narrative, as protection against death, to a writing that is "now linked to sacrifice and the sacrifice of life itself; it is a voluntary obliteration of the self that does not require representation in books because it takes place in the everyday existence of the writer. ${ }^{\prime 79}$ But representation is exactly what Calle and Auster attempt. For both Calle and Auster, self-representation is entangled in their constitutions, impersonations and reconstructions of their 'fictional' selves and repositioning as subject.

\section{The Authorial "Subject"}

Double Game, already a reframing of Calle's projects and Auster's involvement, plays with Calle's and Auster's intrusions in their texts as authorial subject. This transition from author to author/subject relocates not only authorship but also identity, already dislocated and deconstructed. Rather than dismiss the notion of the subject, this repositioning and continual oscillation between author and author/subject demands that we rethink and readdress these already dislocated positions. While we may attempt to situate the subject in Calle's and Auster's work there is also a blurring of these constructed positions of author and subject and their relationship to experience and writing.

\footnotetext{
${ }^{78}$ Derrida's "violent hierarchy" refers to the privileging of one binary over the other, for example: man over woman, or speech over writing. Violent because one is always subordinate to the other-excluded.

${ }^{79}$ Foucault, "What is an Author?", 301.
} 
Calle exposes the overlap between her work and her own experiences through a sharing and a showcasing of her life: for example, the story that we read in The Striptease locates this narrative as connected to her past in which she connects a "performance" to an event from when she was six. Included in the Pompidou catalogue is not only an interview conducted by Christine Macel but also a "psychological assessment" filled in by Calle, her family and friends, sent to them by Damien Hirst. ${ }^{80}$ And so we 'learn' about Calle as perceived through others: her mother Rachel Sindler, her friend Cathy Mespoulede and Calle herself. From the "psychological assessment," which in turn may be only another layering in fictionalized documentation, we learn that: " 8.2 She lists her likes as: breakfast in bed, bullfights, eating with friends, total abandonment of control, drinking and dancing. She enjoys the company of writers and journalists, single people and people who "resist". 8.3 She dislikes children, talking about food whilst eating, sport, the countryside, being dropped by cowardly men without explanation, missing out and spending time with couples and people with children. ${ }^{181}$ She continues to draw attention to her identity outside the text and in doing so, we begin to intertwine and entangle the fictional, the represented and the authorial Calle.

\footnotetext{
${ }^{80}$ Calle often collaborates with various writers, artists and individuals for her work: Hirst, Auster, Baudrillard, Buren. This is most evident in her work now at the Venice Biennale 2007: "I received an email telling me it was over. I didn't know how to answer. It was as if it wasn't meant for me. It ended with the words: Take care of yourself. I took this recommendation literally. I asked a hundred and two women, chosen for their profession, to interpret the letter in their professional capacity. To analyze it, provide a commentary on it, act it, dance it, sing it. Dissect it. Squeeze it dry. Understand for me. Answer for me. It was a way to take the time to break up. At my own pace. A way to take care of myself." Press Release 17/04/07, Venice Biennale 2007. http://uww.culturesfrance.com/pre/medias/dynamic/communique/59/1163.pdf ${ }^{81}$ Calle, Psychological Assessment by Damien Hirst, in M'as-tu vue, unpaginated.
} 
Like Calle, Auster also shares his 'life' through interviews, memoirs, and "autobiographical tales" ${ }^{82}$ The overlap between Auster's own life and Peter Aaron's in Leviathan is explicit: a writer returned from France, makes a living translating books, marries, has a son, marries a second time.... It is not only Aaron who carries the traces of Auster's life, but also Sachs; Sachs' memory of climbing the Statue of Liberty with his mother, an important moment in the narrative, is a memory from Auster's own life. ${ }^{83}$ If indeed Aaron is a linguistic construct of the author Auster then Leviathan enables freeplay not only of the signifier but also "the field of the subject, [where] there is no referent". The relationship between language and representation, difference and différance ${ }^{84}$ is played out in Leviathan: the woman that PA (Peter Aaron/Paul Auster) marries in Leviathan is called Iris, Paul Auster's real wife's name is Siri (Iris backwards); his first wife's name is Lydia, in the novel it is Delia (similar letters); Auster's real son from his first marriage is Daniel, in Leviathan it is David (biblical names beginning with D but also when written these names look very similar: Q2Danid $(20$ daid $)$. Language, play and representation collide.

\footnotetext{
${ }^{82}$ Paul Auster's most recent 'autobiographical' book is The Red Notebook: True Stories (1995) in which he recites 'tales' from his life; there are so many permutations and versions of Auster's accounts that the overlap between the fictional and the lived experiences is never clear. ${ }^{83}$ In The Invention of Solitude, there is a memory of Auster climbing the statue of liberty with his mother--the same story that is retold in Leviathan. Paul Auster, Leviathan, 39.

${ }_{84}$ Derrida's differance is "literally neither a word or a concept." (Derrida, "Différance," 3 ). It is connected to his critique of logocentrism where speech (as presence and authority) is priveledged over writing. It is "purely graphic: it is read, or it is written, but it cannot be heard." (Ibid., 4) It is also connected to deferral-itself a play between absence and presence-where meaning is never fully present but relational in an endless process referring to other absent signifiers.
} 
However, just because Peter Aaron shares the same initials and similar experiences with Paul Auster I would in no way suggest that Aaron is a mimetic copy of Auster and this is clear through the narration of the events that are not connected to Auster's own life and the continual blatant underlining of the fictive. These parallels, often banal, even inconsequential, make any attempt to separate Auster from Aaron a futile exercise. This reinforces the blurring of the author and subject where, "Any concept of the "real", centred self is repudiated; the self is a significant absence approximated through simulations, the constructions of our spectators. ${ }^{\text {"85 }}$

This can also be applied to Calle, for any attempt to define and restrict Calle the author from Calle the performer proves futile as the two overlap and blur, making it difficult to discern who is speaking: "Night falls, I near the lighted windows at the Florian. I pick out Henri B seated at a nook. I photograph the woman sitting next to him, her back to the window. Outside I wait for him. ${ }^{\text {"86 }}$

Madeline Sopasure writes of City of Glass, "Here the space between Auster and "Auster," between the author and the author-character, is crucial. In that "meta" space--the space of metafiction, as it were-Auster stages a complex play with his name, simultaneously associating and disassociating his name and mode of authorship with an author-character who is either a marginal character

\footnotetext{
${ }^{85}$ Jim Peacock, "Carrying the Burden of Representation: Paul Auster's The Book of Illusions," Joumal of American Studies, 40, 1 (2006), 55. .

${ }^{86}$ Calle, Suite vénetienne, Double Game, 96.
} 
or the major figure, the master plotter. ${ }^{n 87}$ In Leviathan, Auster disassociates himself through Peter Aaron (not Paul Auster) but reassociates himself through linguistic name games and Austerian experiences. For Calle, visual representation also reinforces the associations of Calle represented with Calle outside the text but the weaving of fiction (or so we are led to believe) into her narratives forces us to also always disassociate these representations. It is Auster's and Calle's insistence on the texts' connection to lived experiences, while also revealing the fictionality of the text, that enables a movement between rather than an either/or. Sorapure argues that, "The novel [City of Glass] frustrates, as well, the reader's or critic's attempt to locate the real Paul Auster behind the scenes. ${ }^{\text {"88 }}$ Burke also argues that "Once an authorial subject is admitted into the theoretical picture of a text, that text becomes more difficult to govern and delimit, [for] its identity, its separation from other entities is gravely undetermined. ${ }^{\prime 89}$ Attention is thus focused on the relational structures that identify meaning and reference, focusing on the effects of the play of language..$^{90}$ "The circulation of identical signs, "argues Marc Chentier, "is not merely playful: it reinforces the effect of collapse and fold-over. ${ }^{\prime 91}$ But it is again this

\footnotetext{
${ }^{87}$ Madeline Sorapure, "The Detective and the Author: City of Glass." In Beyond the Red Notebook: Essays on Paul Auster, ed. Dennis Barone (Philadelphia: University of Pennsylvania Press, 1995), 85. This is most evident in City of Glass where the main character Quinn, pretends to be Paul Auster, a detective, only to then meet the 'real' Paul Auster--a writer--and his wife Siri (Paul Auster's real wife's name). In fact, I would argue that the themes that I address in this thesis, in relation to Leviathan, are in fact far more pronounced in The New York Trilogy. ${ }_{88}$ Ibid.

${ }^{89}$ Sean Burke, The Death and Return of the Author: Criticism and Subjectivity in Barthes, Foucault and Derrida, 189.

${ }^{90}$ Jonathan Culler, On Deconstruction: Theory and Criticism after Structuralism (USA: Cornell University Press, 1982), 21.

${ }^{91}$ Marc Chénetier, "Paul Auster's Pseudonymous World." In Beyond the Red Notebook: Essays on Paul Auster, ed. Dennis Barone (Philadelphia: University of Pennsylvania Press, 1995), 39.
} 
movement between or "fold-over" of identical and/or misrepresented signs of the author and subject that challenges the unitary and fixity of authorship and representation. Which clues and indications are relevant; which are false and which are only banal revelations?

Calle's tangled construction of "Sophie Calle", through facts, memories, and images and most importantly her stories, like Auster's constructions, parallels and repeats "facts" about Sophie Calle the author. But as Olivier Rollin has pointed out, while we can make a list of the things we know about Sophie Calle the artist, "few secrets have been given away": That she was born on the ninth day of October, that at the age of nine she took her mother's lover to be her real father, that her parents were divorced, that at the age of six she took all her clothes off in a lift... When all is said and done, few secrets have been given away. The false bride has not been stripped bare. ${ }^{92}$

Calle's work explores self-representation through both photography and language. In her diaries, included in M'as-tu vue, she has 'shared' a correspondence with Le Courrier de Ceret in which she has been addressed as Sophie Galle, (thus not Calle by difference of the C) and Sophie Caille and she continues to play with her name suggesting that they could also call her S. Belle, S. Baîlle: "As I wrote to you last week, thank you again for your much appreciated weekly news. I pointed out in my letter that my name is not Sophie

\footnotetext{
${ }^{92}$ Olivier Rollin, "Beet, Alfalfa, etc." in M'as-tu vue, ed. Christine Macel (Paris: Centre National d'Art et de Culture Georges Pompidou, 2003), 139.
} 
Galle, but Sophie Calle... But you have nevertheless not completely complied, for you have this week opted for the admittedly extremely pretty name of Sophe Caille... might I suggest, for the weeks to come, one or two suitable adaptations: S. balle, S. Baîlle, S. pâle, S. mâle, Sophie râle, Sophie raille... to stay in the same vein. Your amie Calle. ${ }^{193}$ Here her play with language is evident and she draws attention to the linguistic changes, or traces, connected to her name which both demands that she be called Calle but also the significance of the similarities and differences. For as Derrida argues, "In a language, in the system of languages there are only differences." 94 The play on the words "amicale/friendly" satisfies on all accounts as it is what is but also is what isn't. This linguistic play focuses on the difference between speech and writing, like Derrida's différance in which the "a" is only seen in the writing of the word (as opposed to Auster's QDaniel and $\mathscr{D}$ awid).

For Calle, substitution often takes place through the replacement of one letter for another: one person for another. In Calle's work, a love letter makes many appearances: She once asked artist Damien Hirst to write a love letter for her: "I met Damien Hirst in Glasgow in 1989. That same evening, I asked him to send me a love letter. ${ }^{95} \mathrm{~A}$ love letter is also the subject of a story about paying a public scribe to write her a letter in Des Histoires Vraies (is Hirst a substitute for the scribe here?); and a love letter reappears again in The Rival, one of an

\footnotetext{
${ }^{93}$ Translated by Christine Macel, "The Author Issue, in M'as-tu vue, ed. Christine Macel (Paris: Centre National d'Art et de Culture Georges Pompidou, 2003), 24.

94 Jacques Derrida, "Différance," 11.

${ }^{95}$ Calle, Psychological Assessment by Damien Hirst in M'as-tu vue. Unpaginated.
} 
additional ten stories included in Des Histoires Vraies; a love letter was 'found' under her husband's typewriter: "At the top of the page I noticed these words were not addressed to me but to the letter " $\mathrm{H}$ ". I crossed out the $\mathrm{H}$ and replaced it with an $\mathrm{S}$. This became the letter I had never received. ${ }^{n 96}$ But in making the substitution, she has indeed received this letter for the substitution of one letter for another displaces the original recipient and Calle thus shifts into her place. The alphabet letter, the graphic mark on a page, as Derrida argues, can always be written in many ways, and thus places the linguistic unit as having no essential features: identity is purely relational. ${ }^{97}$ Calle thus associates herself with the letter through an act of supplementarity.

Calle's replacement of $H$ with $C$ both supplements the intent of the initial linguistic sign but also functions like Derrida's metaphoric replacement in which the linguistic sign becomes a derivation, extension and/or reduction. It is both the rendering accessible as well as the absence: a break in the homogeneity of the system: the supplement. ${ }^{98}$ In Calle's work the supplement, as both replacement and extension, enables meaning to be not only relational but also 'illimitable' for there is no end of substitutions that can be made; "engendering an infinity of new contexts in a manner which is absolutely illimitable. ${ }^{99}$

\footnotetext{
${ }^{96}$ Both The Love Letter about the public scribe and The Rival appear together in Appointment with Sigmund Freud (1998) and Des Histoires Vraies (1994).

97 Jonathan Culler, On Deconstruction: Theory and Criticism after Structuralism, 101.

98 Jaques Derrida, "Signature Event Context," 2-4.

${ }^{99}$ Ibid., 12
} 
The use of replacement and substitution in Calle's work also plays with presence and absence; in this instance, Calle's re-writing and effacement of the first letter (already a replacement for the proper name) mimics Derrida's sense of absence/presence in the trace, for it is not a break with presence but a continuation of presence in the trace-by rendering present in representation. ${ }^{100}$ Calle's photographs and texts therefore continue to present us with a movement between absence/presence, speech/writing and the relational and individual ways in which meaning can be constituted, read, misread, constructed and simultaneously deconstructed.

\section{Writing/Representation Interrupted}

The possibilities for meaning are exaggerated through Calle and Auster's exchange and their own intertextuality between their lives, their fictions and their insertion into each others' texts. This intertextuality not only problematizes the singular relationship of an author and a text but also provides intertextual patterns and exchanges and extratextual connections that debunk notions of origin for there is no singular, essential moment of conception--there is only difference: difference between the physical Calle and Auster and Calle and Auster represented; and difference between the authors, the written texts and their performativity.

100 Ibid., 5-6. 
Calle and Auster's intertwining of texts provides the initial theme of doubling: re-writing, re-marking, re-making, re-telling, copying, and borrowing. And if, according to Barthes, a text, is indeed a "tissue of quotations", it is then the reader who must establish the relationship between the texts through a variety of relational procedures. Calle and Auster present the reader with innumerable possibilities of connections where a variety of doubling strategies and themes of supplementarity encourage plurality of possibility. In Chapter Three I look at how these doubling strategies make it difficult to discern a singular identity through a continual shifting of subjectivity. Through persistent repositioning, inside and outside their texts, their identity as author (and subject) becomes displaced and multiplied.

For example, on the pages of Leviathan, reprinted in Double Game, Calle writes over Auster's words: "She had grown up in Holyoke, Massachusetts- Paris, the only child of parents who were divorced when she was six three. After graduating from high school in 1970, she had gone to New York with the idea of attending art school and becoming a painter university, but she lost interest after one term and dropped out." ${ }^{101}$ (Fig. 20) Calle here has repositioned herself as the author, the reader and the subject.

Shifting identity is, for Stuart Hall, a way in which to displace the fixity of origin [and presence]. He argues, "If 'identities' can only be read against the grain-that is to say, specifically not as that which fixes the play of difference in a ${ }^{101}$ Calle, Double Game, insert. 
point of origin and stability, but as that which is constructed in or through difference and is constantly destabilized by what it leaves out, then how can we understand its meaning and how can we theorize its emergence?"102 Hall continues, suggesting that, "Identities are thus points of temporary attachment to the subject positions which discursive practices construct for us all. ${ }^{103}$ Thus Calle and Auster's continual movement inside and outside their texts, their authorial intrusions and their borrowings of each others' work provide multiple points from which their subject positions can be constructed.

I argue that Calle and Auster's intertextuality also challenges this temporary stability or positioning of identity through the instability of the texts/performances and their supplementary relationship to each other. Aaron must account for the unreliable narrative, which he does by drawing attention to the contestations within the text: differing stories, blurring of facts. Throughout Leviathan, we read conflicting stories of what has happened: Sachs' fall, Maria's relationship with Dimaggio as well as Sachs and Fanny's relationship. Paul Auster's writing, Chentier argues, is a quest: "a quest for some coherence in a chaos of events, be it at the cost of a more or less acute paranoia, such a quest for unstable, elusive meaning among resemblances and possible narratives." ${ }^{104}$ And, according to Whitney Chadwick, Sophie Calle "investigates the lack of a coherent or fixed identity, and the ways identity is produced through

\footnotetext{
102 Stuart Hall, "Who Needs Identity?" In Identity: A Reader, ed. Paul du Gay, Jessica Evans and Peter Redman, (London, Thousand Oaks, New Delhi: Sage Publications, 2000), 19. ${ }^{103}$ Ibid.

${ }^{104}$ Marc Chénetier, "Paul Auster's Pseudonymous World," 41.
} 
investigations of the traces left by the body..." ${ }^{105}$ Calle's photographs also challenge this temporary fixity, and singularity of identity, for the photograph itself acts as a supplement to the event or performance and as Amelia Jones suggests, the photograph indeed can "expose the body itself as supplementary, as both the visible proof of the self and its endless deferral." ${ }^{106}$ "Sophie Calle" and "Paul Auster" become endlessly displaced through the inability of the reader to clearly distinguish: the fictional from the factual, presence from/as absence and the difference between their authorial and subject positions.

In Double Game, her projects are deliberately set up so that each project, like the individual books, begins with "La règle du jeu". For example, The Detective (one of the projects borrowed by Auster) consists of a series of black and white photographs of Calle, taken by a detective who was hired by Calle's mother at her request: "She hired them to follow me, to report my daily activities, and to provide photographic evidence of my existence. ${ }^{107}$ (Fig. 21) The photographs are accompanied by diaristic notes from Calle about her activities: "At 10:40 A.M. I get to la Coupole, 102 boulevard de Montparnasse where I have an appointment with Nathalie M. I do not sit at our usual table, but closer to the

\footnotetext{
${ }^{105}$ Whitney Chadwick, "Body as Subject: Four Contemporary Women Artists." In Beyond French Feminisms: Debates on Women, Politics and Culture in France, 1981-2001, eds. Roger Célestin, Eliane Dalmolin and Isabelle de Courtivron (New York: Palgrave MacMillan, 2003), 150. Chadwick argues that these 'traces' are also Calle's photographs, diaries and records of surveillance.

${ }^{106}$ Jones argues for the suplementarity of the documentation itself. Amelia Jones, "Presence' in Absentia: Experiencing Performance as Documentation," Art Journal, Vol. 56. No. 4 Minter 1997): 14

${ }^{107}$ Calle, The Detective, Double Game, 122-123.
} 
window, and order a café crème." ${ }^{108}$ Also included is the detective's report: "At 10:40 she enters 100 boulevard Montparnasse. At 11:32 the subject comes out of the building in the company of a friend...."109 Even here the facts do not allow for a unified and believable experience-the addresses are different. Calle's "report" and the Detective's official report also differ in their endings. In Calle's narration of events: "Half an hour later, at 6 P.M., I leave the theatre. I walk toward Châtelet. At 7 P.M. 1 arrive at Galerie Chantal Crousel... At 2 A.M. A taxi takes us both [Calle and a friend] to the OK bar...."110 The Detective's Report reads: "At 7:25 the subject leaves the cinema and goes into the FranklinRoosevelt metro station where she boards a train bound for Pont-de-Sèvres. She changes at Trocadéro and takes the direction Nation. At 7:55 the subject gets off the train at the station Denfert-Rochereau. At 8:00 the subject returns home. The surveillance ends." ${ }^{111}$ Here, again, the 'facts' differ. I argue that Calle's photographs and inclusion of contradictory texts work to destabilize and contradict their own author-ity, exposing the constructions and fabrications. The photographs and her written notes both act as supplement to the event, of which we are never sure. The relationship between writing and visual representation is always uneasy, we never know which has the 'upper-hand' as both are always under question.

\footnotetext{
${ }^{108}$ Ibid., 124.

109 Ibid., 129-131.

110 ibid., 126.

111 Ibid., 137. This dialectic relationship is interrupted by a third telling of events as the detective was also followed and photographed by a friend of Calle's. I discuss this more in ChapterThree of this thesis.
} 
The relationship between writing and representation is explained by Toril Moi; she argues that authorship and representation in fact work to reinforce each other, so in order to put an end to the mystified conception of language we need to put an end to and proclaim the "death of the author". ${ }^{112}$ So it is the death of the author that makes possible the closure of representation, writing without referent. ${ }^{113}$ Again linking representation to presence, Burke argues that, "the denial of representation takes the form of a thoroughgoing epistemological skepticism which relentlessly questions the basis and validity of imputing any properties of presence or re-presentation to textuality. ${ }^{n 114}$

Calle (and Auster) insist on their inclusion, their representation--for the text becomes an interplay of relations where everything contains the possibility of being in brackets. Iser suggests that reality reproduced within the fictionalized text presents a sign for something else; "it indicates that original determinacy has been outstripped. ${ }^{115}$ The changability of the signified is, for Iser, the crossing of boundaries, an act of transgression in which, I argue, Calle and Auster participate. Language, for both Calle and Auster, is therefore transformed from denotation to a function of figuration "in order to indicate through its figuration, the linguistic untranslatability of its references. ${ }^{\text {} 116} \mathrm{~A}$ certain ambiguity then exists that allows a "reference" to be conceived, "but cannot be identical to the

\footnotetext{
112 Toril Moi, Sexual Textual Politics: Feminist Literary Theory (London and New York: Routledge, 1985), 8.

${ }^{113}$ Sean Burke, The Death and Return of the Author: Criticism and Subjectivity in Barthes, Foucault and Derrida, 48.

${ }^{114}$ Ibid., 49.

${ }^{115}$ Wolfgang Iser, "Feigning in Fiction," 205.

116 Ibid., 213.
} 
reference. ${ }^{117}$ This fluctuating relationship thus enables ambiguity in the relationship of sign, signified and referent. Calle and Auster foster this ambiguity through the deliberate planting of clues, the points at which meaning and/or fictionality can be revealed. We see examples of this in Leviathan with the planting of the name of the book in Sachs' notes or Calle's last photo in The Striptease which acts as a clue to the fictionality of the event.

Fiction that self-consciously draws attention to the devices of fiction, metafiction, presents us with these references or clues, but it is as if each clue undoes and deconstructs what was written before. ${ }^{118}$ This exposure of the fictionality, in turn, according to Bernstein, exposes the author figure in the act of writing and textual incompleteness: the gaps. ${ }^{119}$ By drawing attention to the subject writing, and the subject's inability to tell the whole story the text thus proposes a web of infinite possibilities of meaning.

\section{The Subject (of) Writing}

It is only through Sachs' death that both Aaron, and by extension Auster, is able to write. Sachs is the 'disappeared' or 'missing' body, the literal "death of the author", but also, I argue, a metonym for writing--the complete obliteration of the

\footnotetext{
117 Ibid., 213.

${ }^{118}$ Stephen Bernstein suggests that in Auster's The Locked Door, "Each sentence erased the sentence before it, each paragraph made the next paragraph impossible." Stephen Bernstein, "'The Question is the Story Itself': Postmodernism and Intertextuality in Auster's New York Trilogy." In Detecting Texts: The Metaphysical Detective Story from Poe to Postmodernism, eds. Patricia Merivale and Susan Elizabeth Sweeny (Philadelphia, Pennsylvania: Pennsylvania Press, 1999), 140.

${ }^{119}$ 'lbid., 141. The gaps are addressed directly in Leviathan by Aaron who announces Sachs' gaps in the telling of the story and also exposes his own gaps in the story. It is most prevalent in Calle and Auster's Gotham Handbook in which Auster writes in his letter to Calle: "I wanted to leave it open enough so that you could find your own way through the ideas." Calle, Gotham Handbook, Double Game, 237.
} 
point of origin which allows writing to begin. Sachs' death is the complete erasure of both the subject and the author, but also the reinstatement of the subject and author, for Auster/Aaron insists that "these stories came straight from Sachs himself. ${ }^{120}$

The literal "death of the author" and his complete annihilation is what Aaron finds hard to accept: "Of all the tragedies my poor friend created for himself, leaving his book unfinished becomes the hardest one to bear. I don't mean to say that books are more important than life, but the fact is that everyone dies, everyone disappears in the end, and if Sachs had managed to finish his book, there's a chance it might have outlived him. ${ }^{121}$ The disappearance of the subject and the "death of the author" enables writing to begin, but here Auster/Aaron also argues for the persistence of the "author"-a position much like Foucault's positioning of the author--somewhere between disappearance and death; where the collective subject replaces the individual subject.

This disappearance of the author becomes linked to the process of writing itself. The performability of this disappearance (and conversely the reappearance) of both author and author/subject can be linked to Derrida's critique of logocentrism, as connected to presence; in which speech is privileged over writing; where speech is related to the presence of the speaker, again linking the primacy of the signified (as presence) with the signifier (as absence of

\footnotetext{
${ }^{120}$ Auster, Leviathan, 34.

121 Ibid., 159.
} 
the signified presence). Presence as essence, origin, word, god, origin, consciousness and identity itself is challenged through the shifting, in both Calle's and Auster's work, of author and subject, particularly as it relates to the performative act of writing.

In an interview, Foucault states: "I believe that it is better to try to understand that someone who is a writer is not simply doing his work in his books in what he publishes, but that his major work, is, in the end, himself in the process of writing his books... the work is more than the work: the subject who is writing the part of the work. ${ }^{\text {122 }}$ Aaron, and not Sachs, thus becomes the subject through his writing of the story. Searching for clues and creating the clues become intertwined. This self-reflexivity forces us to turn around and again contemplate Auster's role in the writing of this book. Thus Auster also becomes the subject in and of his own creation. Thus we have the "triplet" of Auster, Aaron and Sachs as the subject of Leviathan. ${ }^{123}$ For Calle, the performativity of author/subject is also split or triangulated by her roles as author, performer and narrator; each complicated by her use of "l" for all three roles.

For example in Days Under the Sign of $B, C \& W$, one of the projects that Auster authored for Maria, "Calle" writes: "C for Calle \& Calle in Cemetery: Six years ago now, my father and I became the owners of a grave in Montparnasse

\footnotetext{
${ }^{122}$ Michel Foucault in "Postscript: An Interview with Michel Foucault by Charles Raus" in Death and the Labyrinth: The World of Raymond Roussel translated by Charles Raus (London: Athena Press, 1987), 184.

${ }^{123}$ I discuss Auster's uses of the triplet in greater detail in ChapterThree of this thesis.
} 
Cemetery. I remember how long it took to choose between a tomb situated in the front row of the main alley and the one we finally settled on... ${ }^{m 124}$ Here Calle performing Maria performing Calle grounds the performance in her own experiences: buying a gravesite in Montparnasse--a literal tongue in cheek of the inevitable death of the author? The time here, "six years ago" places Calle creating this project, or actually choosing the gravesite, at the same time Auster published Leviathan (1998); this helps reinforce the split subjectivity (Calle/Maria/Calle and author/subject) as well as denying authorial origin as a single moment in time. But Barthes offers another level to a shifting subjectivity, "... today the subject apprehends himself elsewhere, and "subjectivity" can return at another place in the spiral: deconstructed, taken apart, shifted without anchorage: why should I not speak of 'myself' since this 'my' is no longer the 'self'?'125 This split in subjectivity not only splits the speaking subject, but also the logocentric hierarchy of presence collapses in on itself.

The split subject is also addressed by Mikhail Bhaktin who writes: "Even if the author-creator had created the most perfect autobiography, or confession, he would nonetheless have remained, in so far as he had produced it, outside of the universe represented within it. If I tell, (orally or in writing) an event that I have just lived, in so far as I am telling (orally or in writing) this event, I find myself already outside of the time-space in which the event occurred. To identify oneself absolutely with oneself, to identify one's "l" with the " $\mathrm{l}$ " that I tell is as impossible

\footnotetext{
${ }^{124}$ Calle, Days Under the Sign of B,C \&W, Double Game, 26.

${ }^{125}$ Roland Barthes, Roland Barthes by Roland Barthes, 168.
} 
as to lift oneself up by one's hair. ${ }^{126}$ But this seems to be exactly what Calle plays with in the narration of the event in the first person. As noted by Gratton, Double Game's doubleness, or play of doubling is not only through an interplay of "document and fiction, experience and experiment, 'Sophie Calle' and 'Maria Turner', but through temporal interplay of past and present." ${ }^{127}$ As we see in Calle's projects her notes are immediate, first-person narratives written in the present: "At 10:45 A.M. Nathalie M. joins me. l've known her for years. She always seems so fragile. She is beautiful. I am superstitious, so I don't want to speak of "him", of the man who should be following me. I don't know if he is really here. ${ }^{128}$

First person narration is also addressed by Foucault who argues that "in a novel narrated in the first person, neither the first person pronoun, the present indicative tense, nor, for that matter, its signs of localization refer directly to the writer, either to the time he wrote, or to the specific act of writing; rather they stand in for a 'second-self' whose similarity with the author is never fixed and undergoes considerable alteration within the course of a single book. ${ }^{\prime 129}$ Foucault argues that this author-function ${ }^{130}$ "arises out of the division between "actual writer" and "fictional narrator". Calle adds another layer to this division through visual representation. This is further complicated and disrupted in Calle's

\footnotetext{
${ }^{126}$ Mikhail Bakhtin quoted by Tzvetan Todorov, Mikhail Bakhtin: The Dialogical Principle (Manchester: Manchester University Press, 1984), 52.

${ }_{127}$ Gratton, "Experiment and experience in the phototextual work of Sophie Calle," 161.

${ }^{128}$ Calle, The Detective, Double Game, 125.

${ }^{129}$ Foucault, "What is an Author," 308.

${ }^{130}$ Foucault articulates four author-functions in his essay, but for this thesis I am most concerned with this last author-function.
} 
narratives when Calle becomes like Maria, already a palimpsest of Calle; "l" here is writer, performer, narrator; Calle and Maria; and none of these.

Writing [about performance] and performance, argues Peggy Phelan, "is to re-mark again the performative possibilities of writing itself. The act of writing towards disappearance, rather than writing towards preservation, must remember that the after-effect of disappearance is the experience of subjectivity itself. ${ }^{131}$ Calle's reinscription of her absent performance (The Wardrobe, The Chromatic Diet, The Birthday Ceremony, Days Under the Sign B,C \&W enables writing to be performative. Through additional narration, discovery is linked to the double trace--between disappearance and presence-- which reinscribes, retraces the absent performance.

\section{Conclusion}

Calle's and Auster's authorial intrusions into their texts and their movement between author and author/subject enable authorial identity to be simultaneously constructed and deconstructed; the absence and presence of the author in the text is always at play, always tentative. Derrida elaborates on this movement between author and text: "... the line that could separate an author's life from his work, for example, or which, within this life could separate an essentialness or transcendentality from an empirical fact, or, yet again, within his work, an empirical fact from something that is not empirical--this very line

\footnotetext{
${ }^{131}$ Peggy Phelan, "The Ontology of Performance: Representation Without Reproduction," in Unmarked: The Politics of Performance (London and New York: Routledge, 1993), 146.
} 
becomes unclear. Its mark becomes divided; its unity dislocated. ${ }^{132}$ And it is this unity that Auster and Calle challenge through their intrusions, impositions and impersonations.

132 Jacques Derrida, The Ear of the Other, (USA: Schocken Books, 1985), 45. 


\section{Chapter 3: Detectives, Doublings and Displacements}

"Days Under the Sign of $B, C \& W$ : To be like Maria, I spent the day of Tuesday, March 10, 1998 under the sign of B for Big-Time Blonde Bimbo; Tuesday February 16,1998, under the sign of $C$ for Calle \& Calle in the Cemetery; Thursday March 19, 1998, under the sign of C for Confession; and Saturday March 14, 1998, under the sign of $W$ for Weekend in Wallonia." ${ }^{133}$

This first image in Days Under the Sign of $B, C \& W$, authored by Auster for Maria, places Calle at the centre of the photograph surrounded by dead animals. ${ }^{134}$ "To be like Maria, I spent the day of Tuesday March 10, 1998 under the sign of B by taking on the appearance of a Big-Time Blonde Bimbo. (For the model of this photograph, see Paris Match of November 2, 1989, and the portrait of $\mathrm{BB}$, who in recent years has taken her preference for the cause of animals over that of humans to the point of caricature.) ${ }^{135}$ (Fig. 22) Auster does not specify what Maria does on these days so Calle is able to 'interpret' Maria's project-fill in the gaps.

"BB" is an obvious reference to Brigitte Bardot and her animal rights' activism. But in Calle's interpretation, the animals are not living but dead; they are the traces, remnants of a life and a twisted play on fact and fiction and an

\footnotetext{
${ }^{133}$ Calle, Days Under the Sign of B, C \&W, Double Game. 22-23.

134 This image--cropped and reframed--is also the image for the cover of Double Game. Calle being Maria, being Calle, pretending to be Brigitte Bardot.

${ }^{135}$ Ibid., 24-25.
} 
ambiguous reference to Calle as the author and criminal in this 'crime scene'. ${ }^{136}$ This photograph presents us with another layer of impersonation and representation: a layering of Bardot on top of Calle on top of Maria on top of Calle-already deferred and displaced through textual representation.

In this chapter I consider the theoretical significances of Calle's and Auster's use of the detective genre as a mode of inquiry. Through literary tropes specific to the detective genre--a missing body, traces, surveillance, shadowing, doubling, evidence and the search for clues--Calle and Auster explore identity by investigating their roles as author and subject. Their 'quest' enables them to oscillate between the planting of the clues (as criminal) (as author) and the discovering of the clues (as detective) (as reader). Through doublings and displacements it makes it difficult to discern the boundaries of author(s) and subject(s)--the 'crime' is never (re)solved.

\section{Whose Story?}

In the beginning of Auster's novel, the only 'clue', for discovering the identity of the exploded man, is a slip of paper, found in the dead man's wallet, with the initials PA and a phone number. The phone number leads the detectives to Peter Aaron and so begins Aaron's tale of Benjamin Sachs. The "wealth of clues" that usually leads to the identity of an unknown person-drivers' license,

\footnotetext{
${ }^{136}$ Calle's own fascination for, and collection of "stuffed" animals is noted by Olivier Rollin: "She likes animals preferably stuffed ones (her home is full of them...Y You'd think that you were at a taxidermist's...)" Olivier Rolin, "Beet, Alfalfa, etc." in M'as-tu vue, 139.
} 
social security card number--were discovered to be forged or stolen; the body's identity had been completely fabricated.

In Leviathan identity is connected to storytelling. Proper names, fingerprints and physical appearance are proved irrelevant; for it is only through Aaron's storytelling, and indeed Aaron as the 'clue' for the detectives, that the identity of the body is actually discovered. This is exposed almost immediately when Aaron remarks on the detectives' names: "Their names were Worthy and Harris but I forget which one was which." ${ }^{137}$ Identity is presented as something that is constructed, manipulated, appropriated and erased: we see Auster, Aaron, Sachs, Dimaggio, Maria, Lillian (and Calle) exchange places, appearances, experiences, and names; continually standing in for each other. This movement between the characters (and authors) enables identity to be freed from a central static position to one where the movement between, and play of one's identity allows for new meanings to also be constructed.

\section{Auster/Aaron/Sachs/Dimaggio}

\section{Auster/Aaron}

Doubles are pervasive in Auster's work. For not only does Maria represent a doubling of Calle, and Aaron a doubling of Auster but again numerous possibilities begin to emerge and characters begin to collapse into each other as the problematic nature of unitary and fixed subjectivity is exposed; and it is this slippage that becomes a condition of Leviathan itself. ${ }^{138}$ Doubling in Leviathan

\footnotetext{
137 Ibid., 6.

${ }^{138}$ Bernstein, "The Question is the Story Itself': Postmodemism and Intertextuality in Auster's New York Trilogy," 135.
} 
begins with Aaron who acts as a stand-in or supplement for Auster, sharing the same initials and similar life experiences--narrating, writing and constructing Sachs' life. The overlap between Auster and Aaron allows for a doubling and ambiguity of voice: "In other words the whole time l'm here in Vermont writing this story, they'll [the detectives looking for the identity of the exploded man] be busy writing their own story. It will be my story, and once they've finished it, they'll know as much about me as I do about myself." ${ }^{139}$

\section{Aaron/Sachs}

Aaron is not only a stand-in for Auster, but also a stand-in for Sachs. For Aaron insists that "these stories came straight from Sachs himself." ${ }^{140}$ But at the same time, he also questions their authority: "I repeat his comments now, I realize that they could have been entirely false. ${ }^{141}$ The multiple and unreliable narration gives us alternate versions of both Sachs' and Aaron's identity. The detectives discover Aaron's relationship to Sachs in the last few pages of the book when they discover that Sachs has actually been a stand-in for Aaron: "They'd identified the person who had been signing my books, and it turned out to be a friend of mine. A man named Benjamin Sachs. ${ }^{142}$ Leviathan's coils have once again brought us back to the beginning.

\footnotetext{
${ }^{139}$ Auster, Leviathan, 8.

140 Ibid., 34.

141 Ibid., 35.

142 Ibid., 274.
} 
In the beginning of Leviathan, Aaron writes about Sachs: "A life without which I can hardly imagine my own." ${ }^{143}$ The self-reflexivity of statements like these, throughout Leviathan, enables supplementarity. Without the death of Sachs, Aaron would not be writing this particular book that we are reading; and thus by extension, without the death of Sachs, Auster would also not be writing this particular novel. In Leviathan, Sachs and Aaron are given biographical details and experiences belonging to the extratextual Paul Auster thus linking both Sachs and Aaron to Paul Auster the "author".

Aaron as a stand-in for Sachs is perhaps most evident when Aaron physically replaces Sachs and sleeps in his bed: "I spent every night at his house, sleeping in his bed and making love to his wife." ${ }^{144}$ And it is only when Aaron is sleeping with Fanny, standing-in for Sachs, that he discovers things about him that he never knew: "Sachs as seen through Fanny's eyes was a more complicated and troubled person than the one I thought I knew. He wasn't just the ebullient and gifted extrovert who had become my friend, he was also a man who hid himself from others, a man burdened with secrets he had never shared with anyone."145 According to Gayatri Spivak, "Knowledge is not a systematic tracking down of a truth that is hidden and may be found. ${ }^{146}$ It is rather the field of "freeplay, that is to say a field of infinite substitutions in the closure of a finite

\footnotetext{
${ }^{143}$ Ibid., 21.

${ }^{144}$ Ibid., 94

145 Ibid., 96.

${ }^{146}$ Spivak, "Translator's Preface,"XIX.
} 
ensemble. ${ }^{147}$ Thus Aaron's account of Sachs rebukes knowledge and truth in its denial of origin and complete comprehension of the subject. As Sachs himself says, "It's hard enough to keep track of ourselves. Once it comes to other people we don't have a clue."148

When Dwight picks up Sachs and drives him down the dirt road where they encounter Reed Dimaggio (which leads to Sachs' shooting of Dimaggio--the event that is pivotal in the novel), he asks Sachs no questions about his past or his identity-as if it had already been erased (already irrelevant): "...he didn't even bother to ask his name."149 But as Auster has already established, names connected to identity are irrelevant for they can be (ex)changed, forged, replaced and erased. After Sachs shoots Reed Dimaggio he wipes down the truck for fingerprints--the one clue that might give away his name--literally erases his traces. In scouring the truck he finds Dimaggio's passport, which leads Sachs to an imagined identity for Dimaggio: a man who has killed many, a criminal. The passport acts as a false clue, something that leads to misinterpretation of the identity of Dimaggio.

Sachs ends up at Maria's apartment and it is Maria's recognition of the passport photo--as the husband of her best friend, Lillian--that starts a second spiral of substitutions. It turns out that Dimaggio was not a killer, as first assumed by Sachs, but actually a graduate student at Berkeley: "He was a student, an

\footnotetext{
${ }^{147}$ Derrida, "Structure Sign and Play," 7.

${ }^{148}$ Auster, Leviathan, 107.

149 Ibid., 168.
} 
intellectual, a teacher and he and Lillian had lived a rather dull life in Berkeley." And it is this revelation that enables Sachs to 'become' Dimaggio-a physical palimpsest.

\section{Sachs/Dimaggio}

Sachs in turn becomes a substitute for Dimaggio: living in his house, sleeping with Lillian and eventually taking over his "work" ${ }^{151}$ Aaron recounts how easily Sachs 'slipped into' his role: "That was the strangest part of it, he told me: how quickly he digested the whole improbable occurrence." ${ }^{152}$ This substitution enables Sachs to fully identify with himself through impersonation of someone else: "I had found the unifying principle, and this one idea would bring all the broken pieces of myself together." 153 The "unifying principle" (doubling for/as Dimaggio) allows Sachs to erase and rewrite Dimaggio, presenting us with yet another layer of representation. This statement also draws our attention to the literal, physical fragmentation of Sachs' body--now disappeared.

\section{Sachs/Sachs}

If we continue to extend the innumerable examples of substitution I would argue that Sachs, like Auster in his novel and Calle in her photographs, also becomes a supplement to himself: "Every time Sachs posed for a picture, he was

\footnotetext{
${ }^{150}$ Ibid., 183.

${ }^{151}$ Sachs takes over Dimaggio's political agenda and travels the county blowing up "scale-model replicas of the Statue of Liberty standing in public places across America." Auster, Leviathan, 242.

${ }^{152}$ Ibid., 177.

153 Ibid., 256.
} 
forced to impersonate himself, to play the game of pretending to be who he was. ${ }^{154}$ But here we have an even larger game: Sachs' existence in Leviathan is multiple, but always mediated through Aaron, constructed exclusively through the characters' differing stories. Sachs as sign, is always under erasure, always already inhabited by the trace of another sign. The mise-en-abyme begins to collapse onto itself, presenting Sachs, not as a stable signifier but as an unstable signifier which offers an infinite number of substitutions and meanings to be made. Dennis Barone argues that Leviathan is an attempt to locate and establish a stable subject; ${ }^{155}$ I argue that Leviathan presents the instability of the text as a strategy for deconstructing identity. It is in this field of freeplay that Derrida situates the supplement: "permitted by the lack, the absence of a centre or origin, is the movement of supplementarily. One cannot determine the centre, the sign which supplements it, which takes its place in its absence-because the sign adds itself, occurs in addition, over and above, comes as a supplement." ${ }^{156}$

Eric Wirth suggests that in Leviathan, as I have described above, Aaron/Sachs/Dimaggio represent a "triplet": Aaron sleeping in Sachs' bed; Sachs in Dimaggio's. ${ }^{157}$ I would extend this series of substitutions to also include Auster and the reader who, like Aaron and the detectives, continue to look for clues as

\footnotetext{
${ }^{154}$ Ibid., 145. It is interesting to compare this to Yves-Alain Bois' description of Calle, "What she pretends to be building, however, is a character, an identity." It is the "pretending" to which I draw attention here--she is not actually doing this. This reinforces both Auster and Calle's play with identity. Bois, "Paper Tigress," 37.

${ }^{155}$ Dennis Barone, "Introduction: Paul Auster and the Post Modern American Novel," 20.

${ }^{156}$ Derrida, "Structure, Sign and Play," 290. Derrida also argues that freeplay is indeed the disruption of presence.

${ }^{157}$ Eric Wirth, "A Look Back from the Horizon," in Beyond the Red Notebook:

Essays on Paul Auster, ed. Dennis Barone (Philadelphia: University of Pennsylvania

Press, 1995), 178.
} 
to the identity of Sachs. Wirth suggests that this "triplet" makes it difficult to discern if it is "three characters enacting one life or one character living three lives" ${ }^{158}$ I believe that this is a more literal reading of the book and that the differing and contradictory subject positions allow for the movement between: "Can a man fall asleep as one person and wake up as another?" ${ }^{159}$ Supporting Wirth's argument of the triplet would be the 'discovery' of the identity of Sachs in the last pages of Leviathan. The identity of Sachs is threefold: "Sachs was the man who had blown himself up in Wisconsin. Sachs was the man who had killed Reed Dimaggio. Sachs was the Phantom of Liberty. ${ }^{160}$ I argue that this triplication is a way to break away from the stasis of the binary of self/other and character/author and that in triangulating and extending these relationships through substitutions and identities that collapse into each other, we begin to look at meaning and identity as temporary, unstable moments of attachment. ${ }^{161}$

\section{Maria/ Lillian/Calle}

\section{Maria/Calle}

Wirth's analysis of the triplet can also be applied to Calle, Maria and Lillian. We have the obvious exchange of Calle for Maria and Maria for Calle through the 'borrowing' of projects. Maria acts as a stand-in for Calle and Calle is then a stand-in for Maria. Lillian complicates this binary creating a triangulated series of substitutions; for in Leviathan, Maria also doubles for Lillian, the woman whose husband is eventually shot by Sachs-they switch identities--pretending to

\footnotetext{
${ }^{158}$ Ibid., 178.

159 Auster, Leviathan, 118.

160 lbid., 274.

${ }^{161}$ Stuart Hall, “Identity Who Needs It?”, 19.
} 
be each other. But again this triplet is extended through Calle's "borrowing" of Auster's projects that he authored for Maria. When our narrator in Leviathan refers to Maria pretending to be Lillian he says, "She has stepped over the boundaries of self. ${ }^{162}$ By performing Maria's projects authored by Auster, Calle also steps over the "boundaries of self"; Calle thus forms a relationship with Maria, Lillian (through default), Auster and the text. Derrida has elaborated on the "doubly redoubled" removed from a place of origin: "Doubly redoubled: the phrase itself doubles what redoubled alone (in its double sense) already says, thus both saying and enacting doublings. To begin will always be (or prove to have been) redoubling--which is to say no beginning at all." ${ }^{163}$ The real life of Calle becomes intertwined and entangled with her performative and represented self, the life of Maria, Lillian and the life and writing of Auster. Calle's "mimesis both furthers and hinders the disclosure of the thing itself, disclosing the thing by resembling it but obscuring it by substituting a double in place of it." ${ }^{164}$

Wirth's structure of the triplet can also be applied to the artist Sophie Calle who, I propose, can be read as author, narrator and performer (who doesn't always follow or confirm what the author intended and/or what the narrator is telling). Through the structure of this triplet Calle is thus divided, multiplied and triangulated. Bois argues that Calle's "strategies of impersonation" 165 create a continuous narrative; I argue that these "impersonations" and doublings actually

\footnotetext{
${ }^{162}$ Auster, Leviathan, 85.

163 John Sallis, "Doublings," in Derrida: A Critical Reader, ed. David Wood (Oxford: Blackwell Publishers, 1992), 120.

164 Ibid., 122.

165 "Strategies of impersonation" is Yves-Alain Bois's term from "The Paper Tigress," 38.
} 
present a discontinuous narrative. The expected relationships between author, performer and narrator are disrupted by a breaking up of the homogeneic system and structure through a reiteration and often contradictory narrative and/or "visual record". Like Sachs in Leviathan, "Calle" as sign is always under erasure and never the transcendental signified. ${ }^{166}$

For example, in The Birthday Ceremony, Calle as author sets up the rules: "On my birthday I always worry that people will forget me. In 1980, to relieve myself of this anxiety, I decided that every year, if possible, on October 9 , I would invite to dinner the exact number of people corresponding to my age, including one stranger chosen by one of my guests. I did not use the presents received on these occasions. I kept them as tokens of affection. In 1993 at the age of forty, I put an end to this ritual. ${ }^{167}$ But almost immediately, in its third year, Calle, as narrator tells us that she "broke" the author's rules: "1982. Remarks: First break in the ritual. I was away so it was impossible to organize a birthday meal in accordance with the rules of the game. My father gave me the painting, my mother the cooker. Because of its irresistible utility, the latter is represented by the manufacturer's guarantee. ${ }^{168}$ The image that accompanies the text is a sterile photograph, like all the other photographs in this project, presenting a glass medical-like cabinet with a booklet (the manufacturer's guarantee) on the first shelf and the painting on the second. (Fig. 23) The actual ritual of the dinner

\footnotetext{
${ }^{166}$ The transcendental signified is that against which all other meaning is measured. For example, "God". Here, I suggest that "Sophie Calle" is not a transcendental signifier.

${ }_{167}$ Calle, The Birthday Ceremony, Double Game, 96-97.

${ }^{168}$ Ibid., 204-205.
} 
is never seen--never verified, always casting doubt. ${ }^{169}$ Calle as performer is denied a presence in this particular project and thus we must rely on the narrator. We will never know if this particular event was ever experienced. Her relationship to the event moves between author, narrator, and performer (implied). The narrator has exposed the performer's deviance from the "authority" of the author and the author's text. In Calle's projects the performer and the narrator continually challenge (and often disobey) the author's authority.

This project is book-ended by two photographs: a birds' eye view of tables--one before a meal with what appears to be forty chairs (Fig. 24) and the second photograph: the remnants of a meal (used plates, ashtrays, chairs scattered around the table), the traces of the event. (Fig. 25) We are never privileged enough to see the performance of the rituals for they are not represented. Nehema Guralnik suggests that: "Compared with the textual evidence, the photographic testimonies-usually perceived to be an objective method of documentation that uncovers a certain truth, and marks an unarguable presence--are revealed as less reliable and do not fulfill our expectations. ${ }^{170}$ । would argue that Calle's photographs also work to destabilize and contradict what we read or they provide support in such a way that exposes their own construction. In the last photograph of The Striptease, it is the introduction of doubt that also places the preceding images under question. Therefore the

${ }^{169}$ There has been some writing about "doubt" in relation to both books: Calle and doubt (Lawrence Rinder, Yves-Alain Bois, Olivier Rollin) and Auster and doubt (Arthur Saltzman). According to Dennis Barone it is Saltzman who situates Leviathan between the poles of belief and doubt. Barone, "Introduction: Paul Auster and the Post Modern American Novel," 24.

${ }^{170}$ Nehema Guralnik, Sophie Calle: True Stories (Tel Aviv: Tel Aviv Museum of Art, 1997), 218. 
image/text relationship disobeys any hierarchy of image over text, text over image. But, as Bois points out, "Her past only exists through its proof, and this proof is always induced by the author; the scenario that produced it is always described in advance--this is what Calle calls the "rule of the game." ${ }^{\text {"171 }}$ But, as I argue, the rules are never followed.

Calle's disobedience is most evident and more complicated in The Chromatic Diet, one of the projects authored for Maria by Auster. In the introduction to the first section in Double Game, Calle writes: "The author imposes on his creature a chromatic regime...." ${ }^{\prime 12}$ In order to refute the authority of the/an author, Calle both enunciates, performs and reinscribes the text by adding to it. Calle emphasizes Auster's authorial and authoritative voice-and winks at him as she then dismantles its authority. The "règle du jeu" is that Maria restricts herself to "foods of a single colour on any given day. ${ }^{.173}$ While performing Maria's ritualistic Chromatic Diet, Calle adheres to Auster/Maria's rule but also adds her own food for each day; and continues even on those days "that Paul Auster had given his characters the day off." 174 "Monday: Orange. Menu Imposed: purée of carrots, boiled prawns, cantaloupe melon. Paul Auster forgot to mention drinks so I allowed myself to complete his menu with orange juice."175 Exploring "textual incompleteness" and the author's "partial observations" as noted by Aaron, Calle plays out her ritual until the end--continuing on the days

\footnotetext{
${ }^{171}$ Bois, "Paper Tigress," 35.

172 Calle, The Chromatic Diet, Double Game, 10-11.

${ }^{173}$ Auster, Leviathan, 67.

${ }^{174}$ Calle, Double Game, 12-13.

175 Ibid., 14.
} 
Auster did not "mention" in his book. On the Sunday, all the colours are laid out and she invites friends-or so she tells us--to join in her chromatic feast. (Fig. 26) Calle clearly situates Auster as the author and authority of these gestures, leaving Calle to perform and narrate. But Calle not only lives out the sameness, she also highlights her differences--her interaction and collaboration as author, filling in the gaps in the construction of this particular 'borrowed' narrative. She reclaims and re-inscribes her author-ity in the performance through an imposition and narration of the event. Calle rewrites herself on top of Auster's character, already a layer on top of herself. And thus in refusing to follow the rules, Calle refutes the authority of Auster's authorship but inserts her own authorship into the performance and reclaims her space as performer, narrator and author. The tenuous relationship that exists between Calle's roles in her own work and her relationship with Auster and his texts plays with difference and sameness, absence and presence and the instability of her identification in each of these roles: the break in the homogeneic system and structure: the supplement.

This becomes explicit in The Detective where Calle sets up a dialogic relationship between a detective and herself. We are presented with the images, (Fig. 21) presumably taken by the detective, and "The Report" in which her movements are noted by the detective: "At 3:20 the subject takes a drink at the outdoor café in the Tuileries gardens and writes. At 3:55 the subject leaves the café and heads for place de la Concorde. ${ }^{176}$ This project also includes short journal entries by Calle. For example, "At 3:10 P.M. I stop at the Tuileries' 176 Ibid., 135. 
outdoor café and order a beer. I take pleasure in watching "him" [the detective] have his drink at the counter. 4:10 P.M. I leave the Tuileries, cross the Place de la Concorde. At 4:30 P.M. I enter the Palais de la Découverte which seemed a propos. I have an appointment with Jacques M. I see his silhouette..." ${ }^{\text {177 }}$ As I have outlined in Chapter Two, not only do the two texts differ in the events and times in their reports, but on the last page (138), Calle exposes her triangulation of this relationship: "I wanted to have a souvenir of the person who would be following me. I didn't know which day of the week the tailing would take place, so I asked François $M$. to be outside the Palais de la Découverte every day at 5 P.M. and to photograph anyone who seemed to be tailing me. I received the following report, accompanied by a set of photographs..178 (Fig. 27) The pages contain six photographs of "a young man about twenty-five, in a leather jacket with a camera around his neck and a bag over his shoulder." ${ }^{179}$ The inclusion of the photographer being watched/followed/photographed disrupts the binary of voyeur/subject and looking/being seen. ${ }^{180}$ The narrator, at once assumes the position of performer/subject-all details noted in the present tense-again blurring the boundaries between past and present; performance and narration. The narration and the photographs exist as a supplement to the experience.

The performances, texts and photographs all exist in cyclical relations to each other, thus refusing any binaries and hierarchies associated with

\footnotetext{
177 Ibid., 126.

178 Ibid., 138

179 Ibid., 138-9.
} 
reality/fiction, presence/absence, image/text and spoken/written. The Wardrobe consists of a series of photographs of articles of clothing against a white background: articles that Calle, supposedly, sent anonymously to a man that she found attractive. Again the events (Calle sending these items and the recipient wearing the clothes) are not documented--more pronounced here because of the complete lack of context--only the objects of the events as 'proof' are shown. We have the author's "intent" or "règle du jeu": I saw him for the first time in December 1985, at a lecture he was giving. I found him attractive, but one thing bothered me: he was wearing an ugly tie. The next day I anonymously sent him a thin brown tie. Later, I saw him in a restaurant and he was wearing it. Unfortunately it clashed with his shirt. It was then that I decided to take on the task of dressing him from head to toe: I would send him one article of clothing every year at Christmas." ${ }^{181}$ Author, performer and narrator are blurred. It is clear that the sentences included on each photograph are the narration of the event: "In 1986, he received a pair of silk grey socks." ${ }^{182}$ Calle writes "For me, the text is the most important thing... It is not important if someone else takes the photograph but the texts are mine. No one can add a word to them. And I have the impression that if the texts are interesting, people will read them. I've been told that people stay in my shows longer because they read the texts. ${ }^{183}$ But the texts are displaced, and not authenticated, through the lack of the 'event' or performance. The photographs work against the narrator/performer's statements;

\footnotetext{
${ }^{181}$ Calle, The Wardrobe, Double Game, 34-35.

182 Ibid., 37.

${ }^{183}$ Alan Riding, "Keeping it Together By Living Her Life in Public, " New York Times, Arts and Leisure (December 7, 2003): 44/45.
} 
for the "grey" socks look black, the "black sweater" resembles a blue shirt and the pants in the photograph are already worn. Representation is denied a position of truth; Calle and her images, as signs, engage in freeplay in the field of representation.

Obviously, more direct connections can be made between Calle's more 'detective-like' projects like To Follow (where she follows people randomly on the street), The Detective (where she is followed by a detective) and Suite vénitienne (where she follows someone she barely knows to Venice) and Paul Auster's detective fiction where watching, stalking, and following are more predominant themes. One could argue that like Calle's following projects, Aaron's writing becomes an imagining/viewing of the self as other through textual representation. Seeing the self as other in representation is made more explicit in Leviathan; it is Maria who acts as a catalyst for Sachs to see himself in representation through the photographs that she takes of him, thus, according to Varvogli, allowing him "to reestablish a sense of identity in relation to others. ${ }^{n 184}$ But in Calle's work the relationship between self and other is always disrupted through Calle's strategies of impersonation and/or imposition and the inability to determine the edges or limits of her roles.

For Auster/Aaron, Aaron/Sachs, Sachs/Dimaggio, Sachs/Sachs, Calle/Maria, Maria/Lillian, Lillian/Maria, Maria/Calle and Calle (x3) the layering of

\footnotetext{
${ }^{184}$ Varvogli, Aliki. The World that is the Book: Paul Auster's Fiction (Liverpool: Liverpool University Press, 2001), 155.
} 
identity and the slippage between characters and authors becomes

palimpsestuous: a rewriting, a renacting. Calle and Maria, like the other doubles, appear to work in tandem, making it difficult to discern which event and narrated experience belongs to Calle and which to Maria. The trace of the other is always present. When Calle indeed recreates Auster's projects authored for Maria she blurs not only origin but identity-for Calle as Maria as Calle returns us back to Calle the author. The lack of a transcendental signifier "extends the domain and play of signification infinitely. ${ }^{185}$ We are presented with an infinite entanglement, a chain of authorial and subject figures.

The Cartesian concept of identity as fixed, integral, unitary and unified has been replaced with identity that is temporary, divided, multiple and fragmented. Leviathan and Double Game actually disrupt the process of identification. It is the unsolvable mystery. Bois writes about Calle: "All this constant double-game, all this Borgesian delirium of pretence, all these Penelopean constructions of identity endlessly discarded as soon as they threaten to solidify...." Bois continues, "such a mimetic structure ensures both identity ( 1 am the one who changes all the time, I am metamorphosis personified) and non-identity ( 1 am only a perfect copy). ${ }^{n 86}$ The confusion between the textual, narratorial and authorial identities leads us away from stable signifiers and their referents to one

\footnotetext{
${ }^{185}$ Thanks to Alison Russell's article "Deconstructing The New York Trilogy: Paul Auster's AntiDetective Fiction" for pointing to this quote. Jacques Derrida, Writing and Difference (Chicago: University of Chicago Press, 1978), 280.

${ }^{186}$ Bois, "Paper Tigress," 46.
} 
where identity is contextual, momentary, elusive, fluid and constructed within the writing and reading of the text.

\section{The Double in the Detective Genre}

Much of Auster's writing is considered the epitome of the "metaphysical detective story," a genre that asks profound questions about narrative, interpretation, subjectivity and the nature of reality and the limits of knowledge. ${ }^{187}$ Merivale and Sweeny suggest that the metaphysical detective story provides 1) a defeated sleuth. 2) The world, city, text is represented as a labyrinth. 3) The text is seen as an embedded text, mise-en-abyme, textual constraints and/or the text as object. 4) There are a many meaningless clues and evidence. 5) There is a missing person, a double or lost and/or stolen identity. 6) Absence, falseness or the circularity or self-defeating nature refuses any closure. ${ }^{188}$ The protagonist seeks yet fails to find their linear narrative and needs to borrow another identity.

The detective, already an ambiguous figure--outside the regulating power structures, yet restoring order-is exploited by both Calle and Auster ${ }^{189}$ In Double Game and Leviathan, Calle and Auster take on this role of this ambiguous figure who seeks order: Calle though her categorization and detective-like notes; Auster through Aaron who wants to find out "what really happened."

\footnotetext{
${ }^{187}$ Patricia Merivale and Susan Elizabeth Sweeney, "The Game's Afoot: On the Trail of the Metaphysical Detective Story, ${ }^{1} 1$.

${ }^{188}$ Ibid., 12.

189 Joseph S Walker, "Criminality and (Self) Discipline: The Case of Paul Auster," Modern Fiction Studies, Volume 48, no.2 (Summer 2002): 396.
} 
One can immediately see how Auster's novel works within these constraints, yet Leviathan is almost always excluded from discussions about Paul Auster in this context: it is considered one of his more realistic novels since it has a linear narrative, more loosely resembles real life and holds some sort of closure in the discovery of the identity of the unknown body. What I propose here is that Leviathan actually pushes the constraints of the metaphysical detective novel in a number of ways. 1) The identity of Sachs is revealed at the end of the story but it is done in such a way that we always doubt the fact, we are never convinced that the events that are being told actually happened (like Calle's undisclosed performances). 2) Aaron/Auster's text, and contradictory stories, becomes the labyrinth that actual prevents us from finding the 'truth'. 3) We are given themes of displacement, replacement and doubling. 4) Leviathan is full of meaningless parallels and linguistic play. 5) There are authorial games that include Calle's artistic projects. 6) We have a missing person, an unidentified fragmented body which is only given an identity through narration and misnarration as the gaps in the narrative are exposed by our narrator. The multiple voices confuse rather than elucidate and, as Wirth suggests, we are never sure if the three characters are the same person or three people leading the same life. ${ }^{190}$

Writing about Auster's New York Trilogy, Bernstein suggests that it is the authorial intrusion that is the crime and is responsible for the textual instability: "the metaphysical intrusions of authorial figures in all three works: an exploding system of doppelgangers finally collapses into a number of closural scenes of

\footnotetext{
${ }^{190}$ Wirth, "A Look Back from the Horizon," 178.
} 
reading, with reader-writer confrontations that manifest textual instability." ${ }^{191} \mathrm{He}$ argues that the "meta" in The New York Trilogy is the "collective culmination in ambiguity and instability rather than knowledge."192 The reader searches for patterns of meaning while the text "rigorously resists any hermeneutic recuperation." ${ }^{193}$ While Leviathan indeed seems to propose more closure in that the identity of the body has been discovered (or so we are told), it continually draws attention to its own instability, as a text, making us aware of the author's/narrator's doubt and role in the fictional. As Barone suggests, "the truth shifts every few pages, and yet Aaron must tell it-even if he must lie to do so." 194

\section{The Role of the Reader}

In both Auster's and Calle's work strategies of doubling and stand-ins also extend to the reader. For in reading Calle's and Auster's work the reader, as Jeffrey Nealon argues, "comes metafictionally, to identify with the detectives; both are bound up in the metaphysical or epistemological work of interpretation, the work of reading clues and writing a solution." ${ }^{n 195}$ In Leviathan this is blurred as it is both Aaron (as writer), the reader as well as the real detectives who have to chart the significance of the clues and characters encountered. Auster consciously plays with his role (as criminal), deliberately presenting us with conflicting stories, references that move us outside the text and planting clues

\footnotetext{
${ }^{191}$ Stephen Bernstein, "The Question is the Story Itself': Postmodernism and Intertextuality in Auster's New York Trilogy." 135.

192 Ibid., 136.

193 Ibid.

194 Barone "Introduction: Paul Auster and the Post Modern American Novel," 19.

195 Jeffery Nealon, "Work of the Detective, Work of the Writer: Paul Auster's City of Glass," Modern Fiction Studies, no. 42.1 (1996): 91-92.
} 
(i.e. the name of his novel). Auster as the writer/criminal leaves his traces in the pages of the book.

Sorapure argues that the detective (and thus the reader) is also equated with the author: "Establishing causality and eliminating ambiguity, the detective (reader) thus presents his/her "authorial ability" in order to unite the disparate elements into a formal coherence. ${ }^{\text {"196 }}$ Detective, reader and author become blurred. For Barthes, "The reader is the space on which all the quotations that make up writing are inscribed. ${ }^{197}$ The reader must piece together what really happened, bringing to the surface a pattern that the work suggests meaning. ${ }^{198}$ Continuing in this Gordian knot of role-playing, this also places Aaron in the role of the reader trying to "fill in the gaps" of the story: "I wrote a short, preliminary draft in the first month, sticking only to the bare essentials. When the case was still unsolved at that point, I went back to the beginning and started filling in the gaps, expanding each chapter to more than twice its original length. ${ }^{199}$ This is balanced by gaps in Sachs' telling of his own story: "It took him the rest of the night to answer that question. Even though there were gaps, holes in the account I haven't been able to fill." ${ }^{200}$ According to Saltzman, it is Aaron who has to account for the "leakiness, contradiction and dubious leads." 201 I argue that it is also the reader, the writer and the detectives. The reader's role is now multiple:

\footnotetext{
${ }^{196}$ Sorapure, "The Detective and the Author: City of Glass," 77.

${ }_{197}$ Barthes, "Death of the Author," 54.

${ }^{198}$ Culler, On Deconstruction: Theory and Criticism after Structuralism, 37.

199 Auster, Leviathan, 273.

200 Ibid., 250.

201 Saltzman, "Post Hoc Harmonies: Paul Auster's Leviathan," 65.
} 
as reader, as detective, as critic and as author as one seeks to extend, acknowledge and account for one's own "authorial ability"--that undeniable absence/presence that we seem unable to eradicate, whose 'death' continues to haunt us.

Calle's work can also be framed by the metaphysical detective genre; in Double Game, we are continually being led through games of textual and visual reproductions that announce their own construction and instability. 1) There is no resolution or closure, we continually doubt everything we see or read, thus the viewer becomes the "defeated sleuth". 2) The words and photographs lead us in a circular pattern back to the beginning. 3) Sophie Calle represented is always in brackets. 4) There are contradictory clues, traces and evidence. 5) and 6) "Sophie Calle" is never discovered and yet we are always looking for clues. "The arbitrary nature of the sign and the system with no positive terms gives us the paradoxical notion of an instituted "trace," a structure of infinite referral in which there are only traces--traces prior to any entity of which they might be the trace." 202

\section{Traces}

Benjamin's notion of the "construct of the detective story as deriving from the obliteration or fixation of the traces of the individual in the big city crowd" 203 is paramount in thinking about Calle's and Auster's work. The trace for Benjamin,

\footnotetext{
202 Jonathan Culler, On Deconstruction: Theory and Criticism after Structuralism, 101.

${ }^{203}$ Walter Benjamin, The Correspondence of Walter Benjamin, 1910-1940, eds. Gershom Scholem and Theodor W. Adorno. (Chicago: University of Chicago Press, 1994), 586
} 
"is an appearance of nearness, however far removed from the thing that left it behind may be. ${ }^{204}$ If we extend this to Leviathan, then it would appear that the text replaces the city in which the individual (identity) is obliterated but also reconstructed. Like the play between the death and return of the author we are still looking, trying to give meaning to these traces that are left behind. Spivak argues that trace cannot be a master word: a mark of presence, origin and mastery but rather Derrida's trace-is the "mark of the absence of a presence, an always already absent present, of the lack at the origin that is the condition of thought and experience." ${ }^{205}$ For Derrida the trace is, "Always differing and deferring, the trace is never as it is in the presentation of itself. It erases itself in presenting itself, muffles itself in resonating, like the writing itself, inscribing its pyramid in difference. ${ }^{\text {206 }}$

The obliteration of the trace also figures in the work of Sophie Calle. Baudrillard writes about Calle's Suite vénitienne: "It consists of following someone step by step, of erasing his traces along the way, and no one can live without traces. If you leave no traces, or if someone has taken it upon himself to wipe them out, you are as good as dead. ${ }^{207}$ Therefore this play of traces in the work of both Calle and Auster gets caught up in the absence and presence of the author, the subject and writing itself. The death of the author therefore cannot be a complete obliteration. For traces, clues, linguistic marks on the page all play

\footnotetext{
204 Ibid.

205 It is interesting to note that Spivak draws attention to trace in French, its strong implications of track, footprint. Spivak, "Translator's Preface," xvii.

206 Derrida, "Différance," 23.

${ }^{207}$ Baudrillard, "Please Follow Me," 78.B
} 
with the absence and presence typical of the detective novel: the quest for identity.

\section{Conclusion}

Through poststructuralist strategies of doubling, stand-ins, supplementarity and impersonation within the detective genre, or more specifically the metaphysical detective genre, Calle and Auster deny the fixity of identity and representation. "Sophie Calle" and "Paul Auster" are continually displaced, misplaced and replaced. Through a redoubling of their positions as author and subject, refusing to be "erased" or "obliterated", Calle's and Auster's authorial traces also implicate the reader in the text. 


\section{Conclusion: ConTEXTS: "Doubts and Derisions"208}

"For her next project, Maria took a temporary job as a chambermaid in a large mid-town hotel. The point was to gather information about the guests, not in any intrusive or compromising way. She intentionally avoided them in fact, restricting herself to what could be learned from the objects scattered about their rooms. Again she took photographs; again she invented life stories for them based on the evidence that was available to her. ${ }^{209}$ Auster's text describes Maria's project 'borrowed' from Calle's project: The Hotel: "On Monday, February 1981, I was hired as a temporary chambermaid for three weeks in a Venetian hotel. I was assigned twelve bedrooms on the fourth floor. In the course of my cleaning duties, I examined the personal belongings of the hotel guests and observed through details, lives which remained unknown to me. On Friday, March 6, the job came to an end."210

Calle continues: "Monday February 16, 10 A.M. I go into room 44... For his breakfast, simply a cup of coffee. He hasn't touched the banana. In the wardrobe, his only clothing is a sheepskin jacket. In one of its pockets, I find a diary with German writing, a language which I don't speak. ...11:30 A.M. He has left without revealing himself. Under the pillow, the man has left his handkerchief." 211

\footnotetext{
${ }^{208}$ Barthes, "The Death of the Author, 50.

${ }^{209}$ Auster, Leviathan, 70.

${ }^{210}$ Calle, The Hotel, Double Game, 140-141.

${ }^{211}$ Ibid., 150.
} 
Opposite Calle's text, there are a series of photographs of room 44 (Fig. 29 ), it is the unmade beds with the impressions in the sheets, the imprint of the body, the trace that draws my eye. I look at each of the images on the page as though they were clues for determining the identity of the occupant of the room-the anonymous, mysterious body who has left these traces. I begin to fabricate a life... the daily rituals, the patterns, the designs. Bois's quote resonates in my head: "What she pretends to be building however is a character, an identity."212 All the time.

In Calle's and Auster's texts, the construction and fictionality of identity and its relationship to representation is investigated; The Hotel self-consciously makes the construction of identity obvious and literal. But Calle's and Auster's constitutions of identity extend to their authorial selves. Through a series of reconstructions and reproductions, Calle and Auster's "double games" challenge the authority of authorship, not through a complete erasure of the author but rather through the creation of a complex web in which the author is deferred, displaced, multiplied and relocated-continually. By 'borrowing' each others' texts and inserting their individual authorial figures into the texts, Calle and Auster are able to move between the author and the author/subject; this oscillation between enables Calle and Auster to highlight not only the similarities between the author and the author/subject but also the differences and inconsistencies.

${ }^{212}$ Bois, "Paper Tigress," 37. 


\section{Singular Relationship Disrupted}

As I have discussed in Chapter Two, the 'singular' relationship of an author to his/her text, as outlined by Foucault, is not only fractured by Calle's and Auster's borrowings, but also exploded through their authorial intrusions into the texts: refusing and denying the "obliteration" or "death of the author" through a crossing of boundaries between fact and fiction and overt parallels between the physical Calle and Auster and the textual Calle and Auster. The text becomes an arena in which presence and absence of the author is always at play, always tentative, continually repositioned; a space in which controversy and contradiction can prevail; a space where boundaries can be crossed and rules broken: where the texts enter "into dialogue, into parody, into contestation". ${ }^{213}$

\section{Rendering Visible: Presence}

The rendering visible of the 'disappeared' author, through an interplay of extratextual and intertextual connections, not only points to the author outside the text, but, at the same time, deconstructs this authoritative position and role. Through perpetual movement between the author writing (as outside the text) and the author/subject in the act of writing (as inside the text), Calle and Auster negotiate the materiality of this continually shifting (and constituted) identity (authorial identity, performative identity and the identity of the various subjects or characters: Sachs, Pierre D., the hotel guests etc.). By drawing attention to the construction of identity, through the exposure of the fictionality and/or the gaps in their narratives, Calle and Auster force the reader to trace out 'meaning' through

\footnotetext{
${ }^{213}$ Barthes, "The Death of the Author," 54.
} 
a series of relational procedures. Aaron/Auster observes Maria/Calle: "Everything was play for Maria, a call to constant invention. It was all fairly childish, I suppose, but Maria took these escapades seriously--not as diversions but as experiments, studies in the shifting nature of the self." ${ }^{214}$

\section{Writing and Representation: Sophie Calle}

But Calle/Maria's "experiments" never follow the rules of the game, the rules invented by the 'author' for Calle usually breaks the rule-almost immediately. Calle continually questions author-ity, her own and Auster's. Through confrontations and contestations with the texts, Calle also protests the 'singularity' of the relationship of author/text through her inclusion of herself as author/subject. Through visual and textual constructions, Calle is not only continually repositioning and questioning the authority of the author, but also the authority of representation.

\section{Writing and Representation: Paul Auster}

Auster, too, challenges and confronts the constructs of writing and representation through a blurring of boundaries between fact and fiction, autobiography and the novel. As we initially read in the publisher's note: "... any resemblance to actual persons, living or dead, events or locales is entirely coincidental. ${ }^{215}$ After reading Leviathan and Double Game, we now have more 'proof' that this statement is indeed false. Or is it? Coincidence, doubt and denial are always already present. Through elaborate linguistic games, extratextual parallels and references, Auster explodes any centering and unifying conventions of a genre. He

\footnotetext{
214 Auster, Leviathan, 86.

215 Ibid., copyright page.
} 
disobeys all constructs, expectations and 'rules' and also, like Calle, the written word (of which he is also the author). Auster has removed himself from the position of 'master plotter': his author-ity is already denied.

\section{Obedience}

Or is Auster merely disobeying the publisher's note? Obedience and disobedience are also entangled in these authorial games. Calle's first book in the Double Game Series, De L'Obéissance, is The Chromatic Diet that Auster authored for Maria. As discussed in Chapter Three, Calle draws attention to her deviations and pronounces her contestations with Auster's authorship: his telling and her performance: the gaps, the differences. Calle notes: "I changed this menu [Wednesday: White] because I was not satisfied with the yellow colour of the potatoes, and added: Rice, Milk. ${ }^{216}$

\section{Gaps}

The highlighting of the gaps in Leviathan, by both Calle and Auster (through Aaron's telling of Sachs' story), refutes conceptions of a text as whole-associated with completeness, finality, closure and fixity; thus forcing us to reexamine the contradictions, gaps or spaces within the text itself. "We return to those empty spaces that have been masked by omission or concealed in a false and misleading plentitude. ${ }^{n 217}$ Foucault continues: the point is made not through

\footnotetext{
${ }^{216}$ Calle, The Chromatic Diet, Double Game, 16.

217 Foucault, "What is an Author?", 312.
} 
the words but "their relationships and in the distance that separates them." ${ }^{218}$ So meaning is always already relational.

\section{Rendering Visible: Absence}

The gaps, the empty spaces also provide another layering of absence and presence. The gaps can be read as clues or traces of the disappeared author, an endless form of deferral. Endless deferral of the author-figure is also made explicit through strategies of doubling and supplementarity; as the presence of an originary and fixed author is always denied. But the texts demand that we conceive and construct the author-figure(s) who are represented. For in the narration of their stories, Calle and Auster present a process of identification where momentary attachment and construction of identity is entangled in the larger system of representation and meaning. Through their intertextuality that is inextricably bound to truth and fiction, and self-representation, Calle and Auster continue to play and present us with narratives that may or may not relate to their extratextual lives.

\section{Knowledge Denied}

Through a layering of fiction upon fiction (that offers some parallels with Auster's and Calle's life outside the text) the reader is drawn into their deconstructive games where the reader is able to find extratextual patterns and intertextual designs, but these coils are often proved inactual, inauthentic and inadequate. Wirth has pointed out, that in Auster's world: "false speech" is as

218 Ibid. 
meaningless as "true speech." ${ }^{219}$ Knowledge itself is, also, denied an authoritative position: it is unpredictable, based upon chance and always in doubt: a reversal of the detective fiction genre where the clues lead to a 'revelation', the solving of the mystery: closure, finality--where there is never any doubt.

\section{Entirely Truthful?}

Through the process of reading, both Leviathan and Double Game, we realize that Calle and Auster have not been entirely truthful with us. But in reading Double Game and Leviathan truth and fiction have collapsed in on each other: how then are we to distinguish truth from fiction and the rules from the game? Their interaction entangles their stories; opening up the texts so that they may be retold, reinscribed and reinvented. The rules of the game have changed and so has the event, through retelling, retracing and redoubling: a rewriting: a palimpsest--layered upon another palimpsest, upon another...

\section{Fictions}

Paul John Eakin argues that, "autobiographical truth is not a fixed but an evolving content in an intricate process of self-discovery and self-creation, and further, that the self that is the centre of all autobiographical is necessarily a fictive structure. ${ }^{220}$ But for Calle and Auster the structure of autobiography and even, I argue, autofiction, is itself proven fictive, since the boundaries between

\footnotetext{
219 Eric Wirth, "A Look Back From the Horizon," 177.

${ }^{220}$ Paul John Eakin, Fictions in Autobiography: Studies in the Art of Self-Invention (Princeton, New Jersey, Princeton University Press, 1985), 3.
} 
fiction, non-fiction and autofiction have been eroded. Autofiction, often associated with Calle's work does not account for the shift and displacement of the author/subject which occurs when Calle is authored by Auster. Auster's and Calle's texts become places of contestations and confrontations where nothing can be assumed to be as it was but rather as if it is. For temporal displacement also becomes entangled in this movement between: between texts, between authors, between fact and fiction.

\section{Storytelling}

"When you tell your own story it's always storytelling. People talk about true stories. As if there could be such a thing as true stories; events occur in one direction and we recount them in the opposite direction. Autobiography, novel, it's all the same. The same thing, the same trickery."221 Gratton is quoting Dubrovsky quoting Sartre-the mise-en-abyme is always at play as the text becomes "a tissue of quotations".

\section{Blurring the Boundaries Even Further...}

This blurring of authorial boundaries is extended even further by Calle, for on the inside and back cover of Des Histoires Vraies, a book published by Actes Sud and not connected to the projects included in Double Game, or Paul Auster, there are quotes from Leviathan, describing Maria. The inside cover states:

\footnotetext{
${ }^{221}$ This quote is from Johnnie Gratton, quoting Serge Dubrouvsky's narrator in Le Livre Brisé (Paris, Grasset, 1989), who quotes the diary of Antoine Roquentin, the hero of John Paul Sartre's novel La Nausée. Gratton, "Sophie Calle's Des Histoires Vraies: Irony and Beyond," in Phototextualities: Intersections of Photography and Narrative. Eds. Alex Hughes and Andrea Noble (Albuquerque: University of New Mexico Press, 2003)191. The translation is Johnnie Gratton's.
} 
"[She] was an artist, but the work she did had nothing to do with creating objects commonly defined as art. Some people called her a photographer, others referred to her as a conceptualist, still others considered her a writer, but none of these descriptions was accurate, and in the end I don't think she can be pigeonholed in any way." 222 Here again the text becomes the space where games are twisted and turned, for Leviathan has nothing to do with Des Histoires Vraies and Auster is actually describing Maria, obviously based on Calle, but as I have suggested in Chapter Three of this thesis: Maria and Calle are not interchangeable. Or are they? Calle's identity is always fluid as it keeps moving, not only between her roles as author and author/subject, or between Auster and herself as author, but also between herself and Maria.

The reader also gets caught playing Auster's and Calle's games, caught constructing and simultaneously deconstructing the position of author and author/subject and its relationship to representation and identity. Through authorial and linguistic games "Calle" and "Auster" are displaced, misplaced and thus the quest continues.

\footnotetext{
222 I have used Paul Auster's writing for the English translation here. In Des Histoires Vraies this quote is written in French. Auster, Leviathan, 66-67.
} 


\section{Figures}

The autbor extends special thanks to Sopbie Calle for permission to mingle fact witb fiction.

PENGUIN MOOKS

Published by the Penguin Group

Penguin Group (USA) Inc, 375 Hudson Street, New York, New York 10014, U.S.A.

Penguin Books Ltd, 80 Strand, London WC2R ORL, England

Penguin Books Australia Ld, 250 Camberwell Rosd, Camberwell, Victoria 3124, Australia

Penguin Books Canada Led, 10 Alcorn Avenwe, Toronto, Ontario, Canada M4V 3B2

Penguin Books India (P) Led, 11 Community Centre, Panchsheel Park, New Delhi - 110 017, India

Penguin Group (NZ), cnr Airborne and Rosedale Roads, Albany, Auckland 1310, New Zealand

Penguin Books (South Africa) (Pry) Led, 24 Sturdec Avenue,

Rosehank, Johannesburg 2196, South Africa

Penguin Books Lud, Registered Offices: 80 Strand, London WC2R ORL, England

First published in the United States of America by Viking Penguin,

a division of Penguin Books USA Inc, 1992

Published in Penguin Hooks 1993

30292827262524232221

Copyright O Paul Auster, 1992

All rights reserved

PULLISHER's NOTE

This is a work of fiction. Names, characters, places, and incidents either are the product of the author's imagination or are used fctitiously, and any resemblence to actual persons, living or dead, events, or locales is entirely coincidental.

THE LBRAKY OF CONGRESS HAS CATALOGUED THE HARDCOVER AS FOLLOW':

Auster, Paul, 1947-

Leviachan/Paul Auster.

p. cm.

ISBN 0-670-84676-7 (he.)

ISBN 01401.78139 (pbk.)

1. Title.

PS3551.U77L48 1992

$813: 34-d c 20 \quad 92-1282$

Printed in the United Stutes of America

Set in Garamond No. 3

Designed by Cheryl L. Cipriani

Except in the United Stares of America, this book is sold subject to the condition char it shall not, by way of trade or orherwise, be lent, re-sold, hired out, or otherwise circulated without the publisher's prior consent in any form of binding or cover other than that in which it is published and without a similar condition including this condition

being imposed on the subsequent purchaset.

Figure 1.

Paul Auster, Leviathan (USA: Penguin Books, 1992), copyright page. 
Fist published in Lidtho in 1999 \&y Vioferte Editions, an imprim of Volette Limited 1 Petham Road Londen W1498R

Dosigned and art diread hy Frast Design, London Printed in haly by Ciratiche Milant

$$
\text { All rights reaterod }
$$

(1) Viokette Limitcd 1999

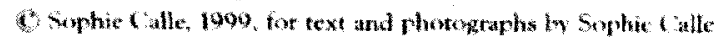
C. Pul Auster, 1999, for text ly Puil Auster

Sophic calle is hereby dentified at ather of this nork in acootdance with section 77 of the Copyright. Droigns wh Paterts Act $198 \%$

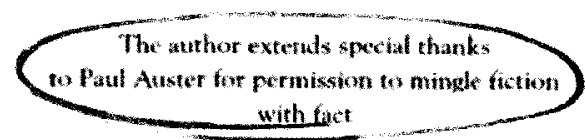

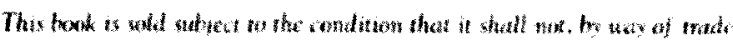

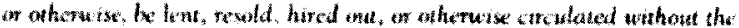

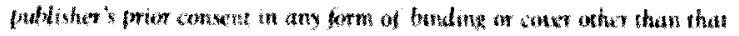

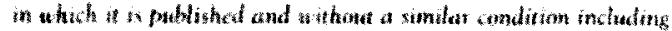

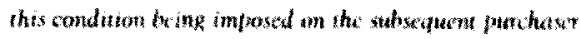

Extrace from Pat Auster's novel, Latathar, are reprined by kind permisxion of Viking Penquin. s. division of Penguin Broks $15 \mathrm{~A}$ In New York, and Faher \& Faher Linited, Lamdion

Sure toutionn was translated from the French by I Many Batash and Dann Hatfeld and first published in English in 1988 ly lwa Press, Seatle Adlitional trankation by Charles Penwarden, Paris

Cower and page 25, portrit of Sophie Calle by lean Baptiste Mondin,

A 4 ip recond the this book is asulate from the Brivish librats

ISBN $1.000828 .06,(\mathrm{hb})$ ISDN 1900k28-08.1 (pb)

Figure 2.

Sophie Calle, Double Game (London: Violette Editions, 1999), copyright page. 
The autbor extends special thanks to Sopbie Calle for permission to mingle fact with fiction.

PENGUIN EOOKS

Published by the Penguin Group

Penguin Group f(USA) Inc., 375 Hudsen Street, New York, New York 10014, U.S.A.

Penguin Books Ltd, 80 Strand, London WC2R ORL, England

Penguin Books Australia Ltd, 250 Camberwell Road, Camberwell, Victoria 3124, Australia

Penguin Books Canada Lrd, 10 Alcorn Avenue, Toronto, Ontario, Canada M4V 3B2

Penguin Books India (P) Ltd, 11 Community Centre, Panchsheel Park, New Delhi - 110 017, Indi

Penguin Group (NZ), enr Airborne and Rosedale Rosds, Albany, Auckland 1310, New Zealand

Penguin Books (South Africa) (Pty) Ltd, 24 Sturdee Avenue,

Roschank, Johannesburg 2196, South Africa

Penguin Books Ltd, Registered Offices: 80 Strand, London WC2R ORL., England

Fitst published in the United States of America by Viking Penguin,

a division of Penguin Books USA Ine., 1992

Published in Penguin Books 1993

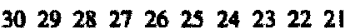

Copyright Paul Auster, 1992

All rights temed

TLat.isher's note

This is a work of fiction. Names, characters, places, and incidents either are the product

of the author's imagination or are used fictitiously, and any resemblance to actual persons,

living or dead, events, of locales is entirely coineidentul.

THE EHAMARY OF CONGRESS HAS CATALOGURD THE HARDCOVER AS EOLOWW:

Auster, Paul, 1947=-

Leviathan/Paul Auster.

p. $\mathrm{cm}$.

ISBN 0-670-84676.7 (he.)

ISBN 01401.78139 (pbk.)

I. Tirle.

PS3551.U77L48 1992

$813.54-d c 20 \quad 92-1282$

Printed in the United States of America

Set in Garamond $\mathrm{Na} 3$

Designed by Cheryl L. Cipriani

Except in the Unired Sutes of Ameticn, this book is sold subject to the condition that it shall not. by way of trade or ocherwise, be lent, re-sold, hised out, or ocherwise circulated without the publisher's prior consent in any form of binding or cover other than that in which it is published and withour a similar condition including this condition being imposed on the subsequent purchaset.

\section{Figure 3.}

Auster, Leviathan, copyright page. 


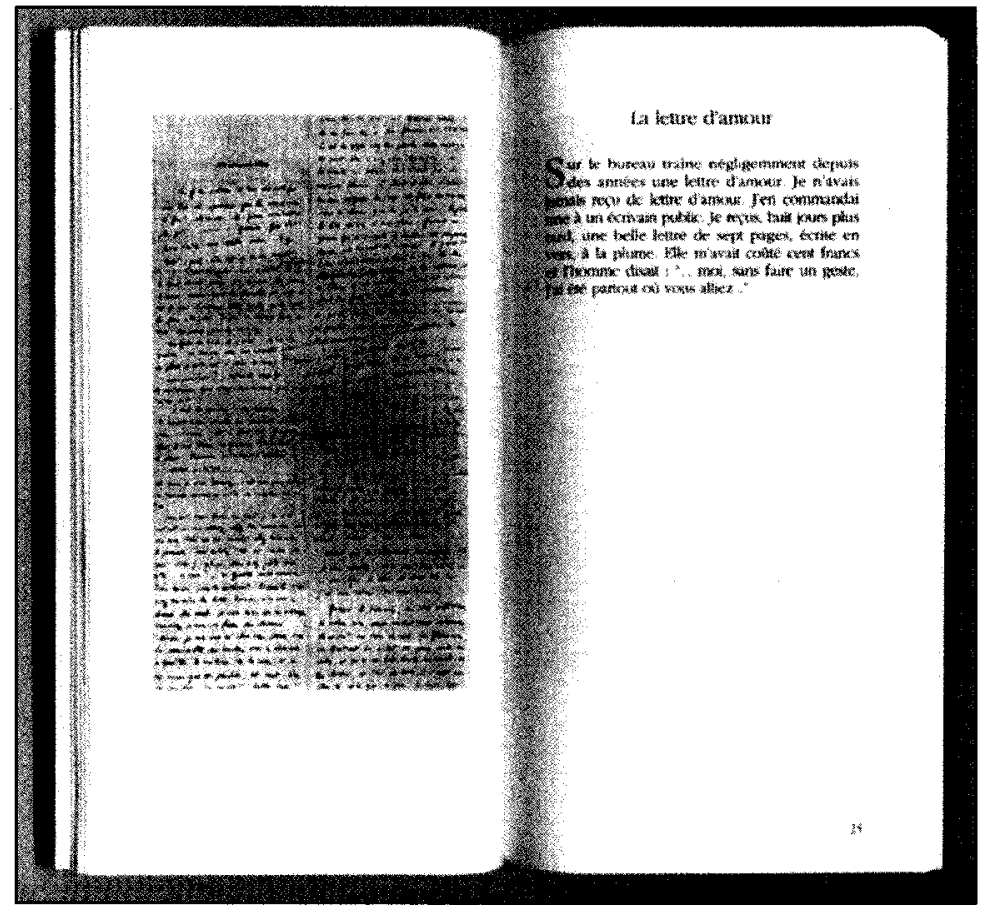

Figure 4.

Calle, La Lettre D’Amour, Des Histoires Vraies (France: Actes Sud, 1998), 24-25.

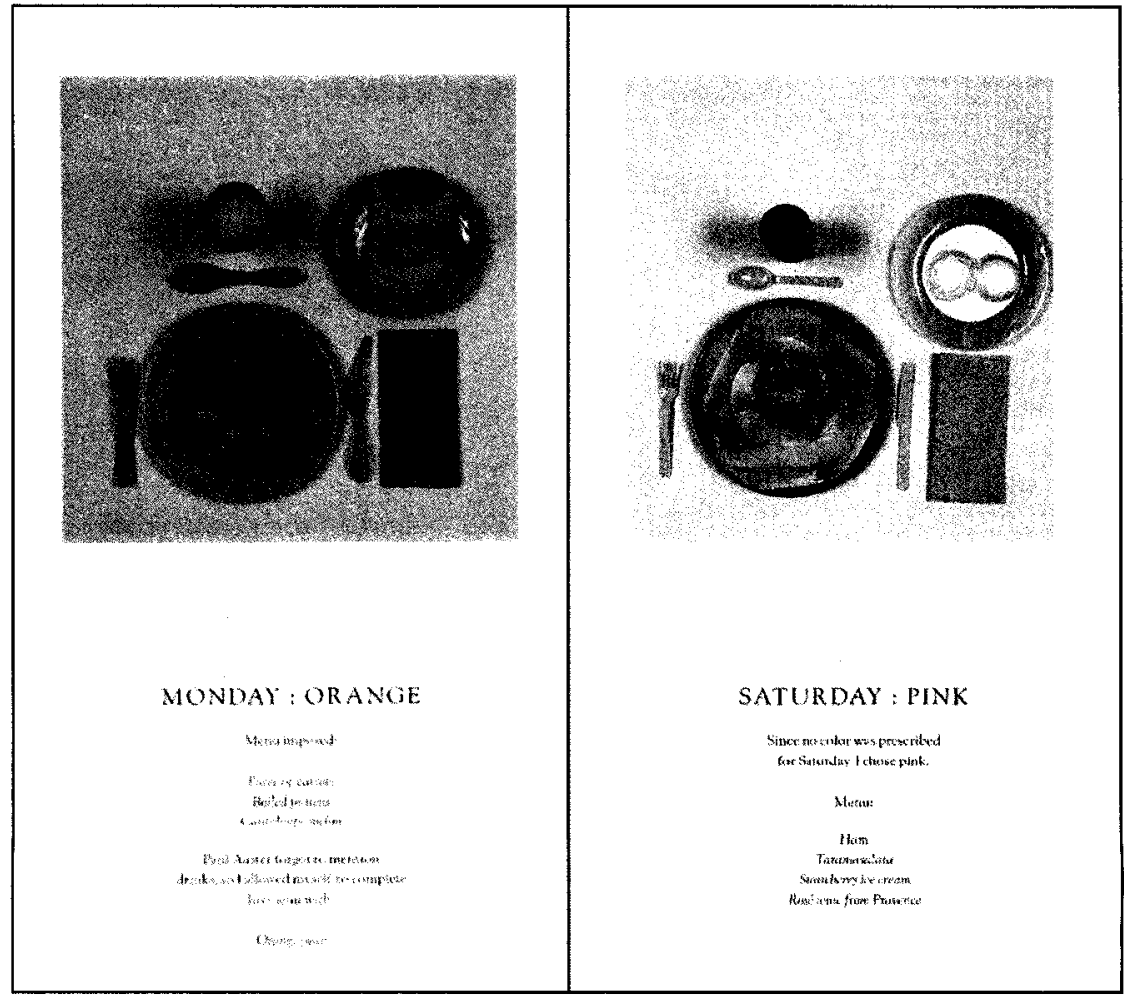

Figure 5.

Calle, Chromatic Diet, Double Game, 14 and 19. 


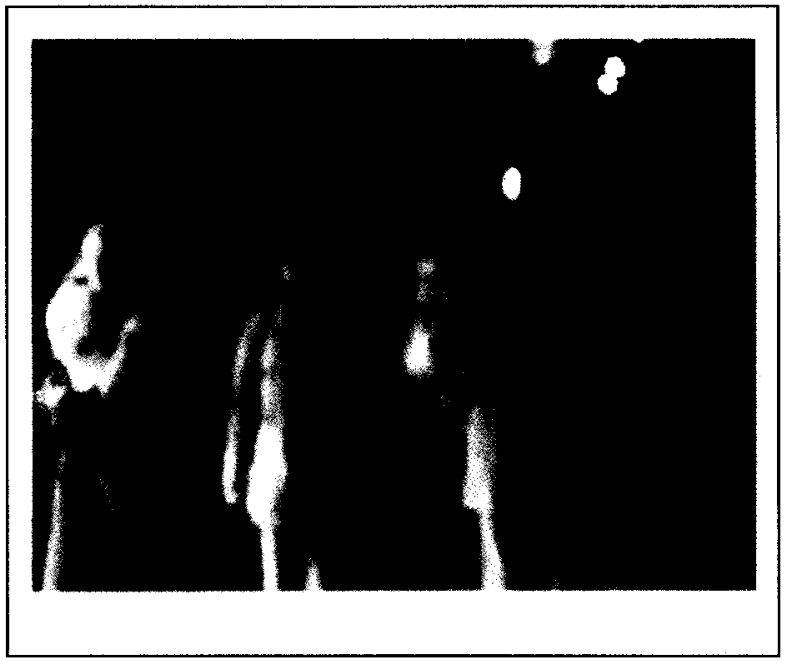

Figure 6.

Calle, Suite vénetienne, Double Game, 109.

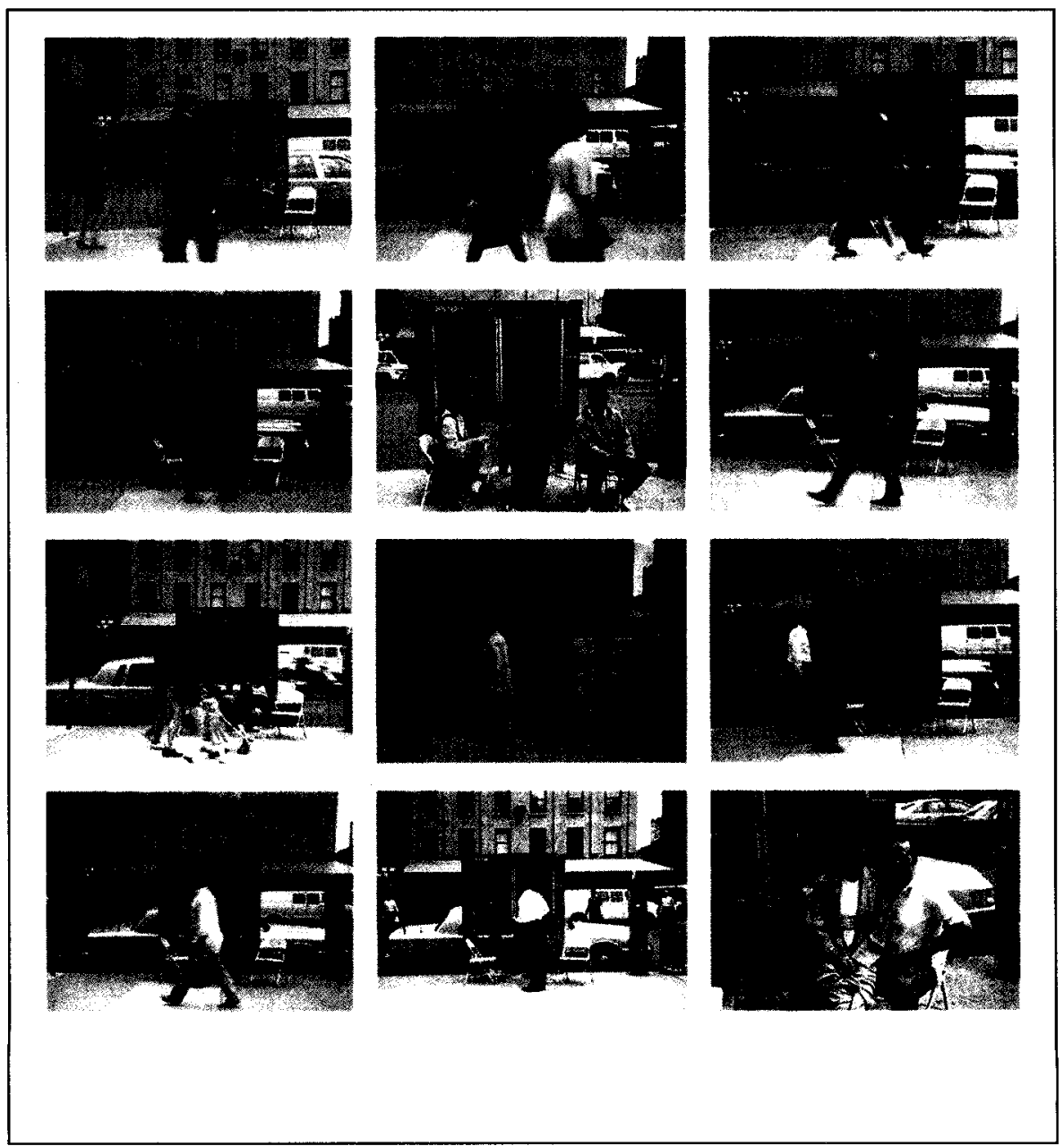

Figure 7.

Calle, Gotham City, Double Game, 255. 


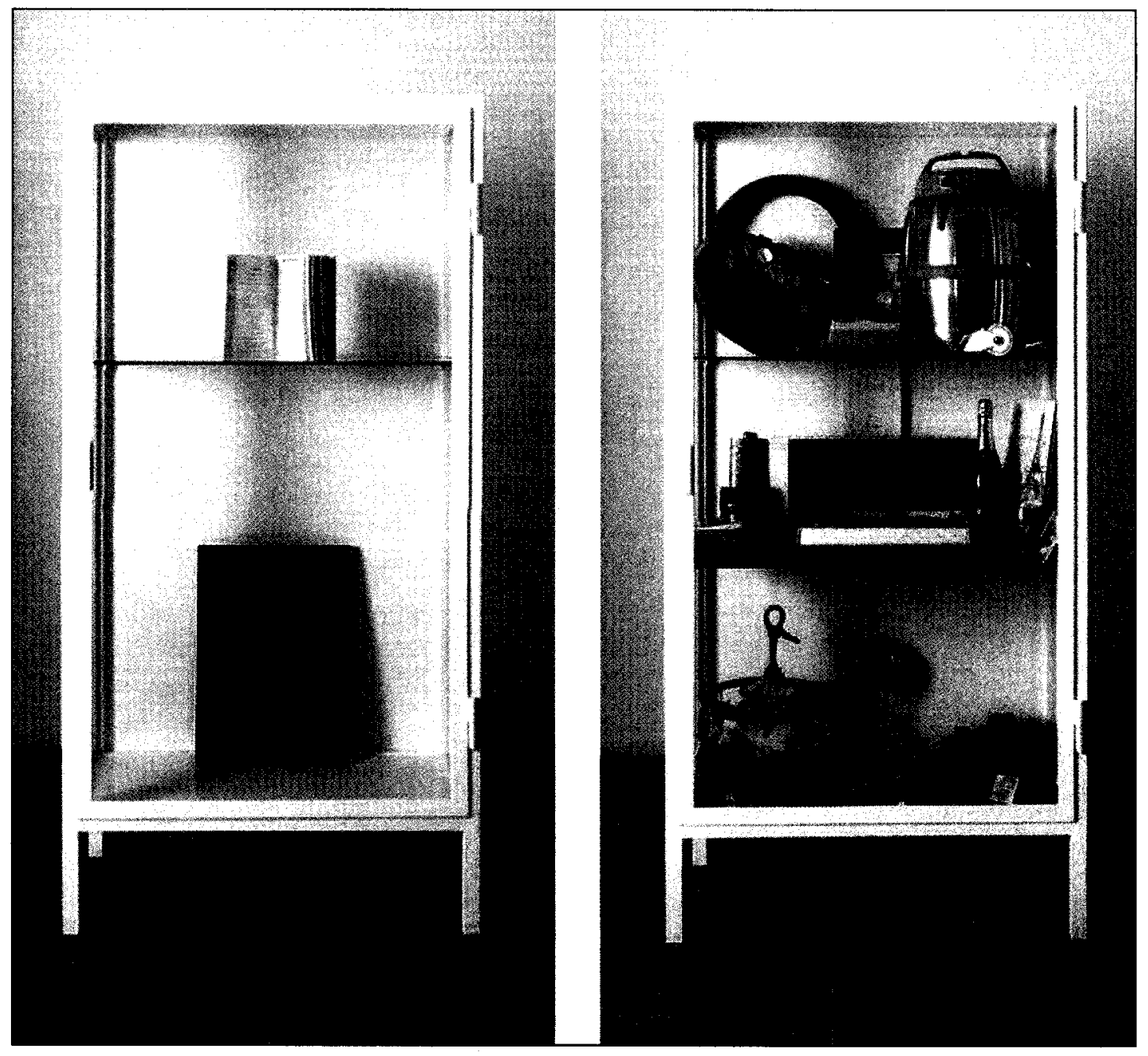

Figure 8.

Calle, The Birthday Ceremony, Double Game, 205 and 209. 


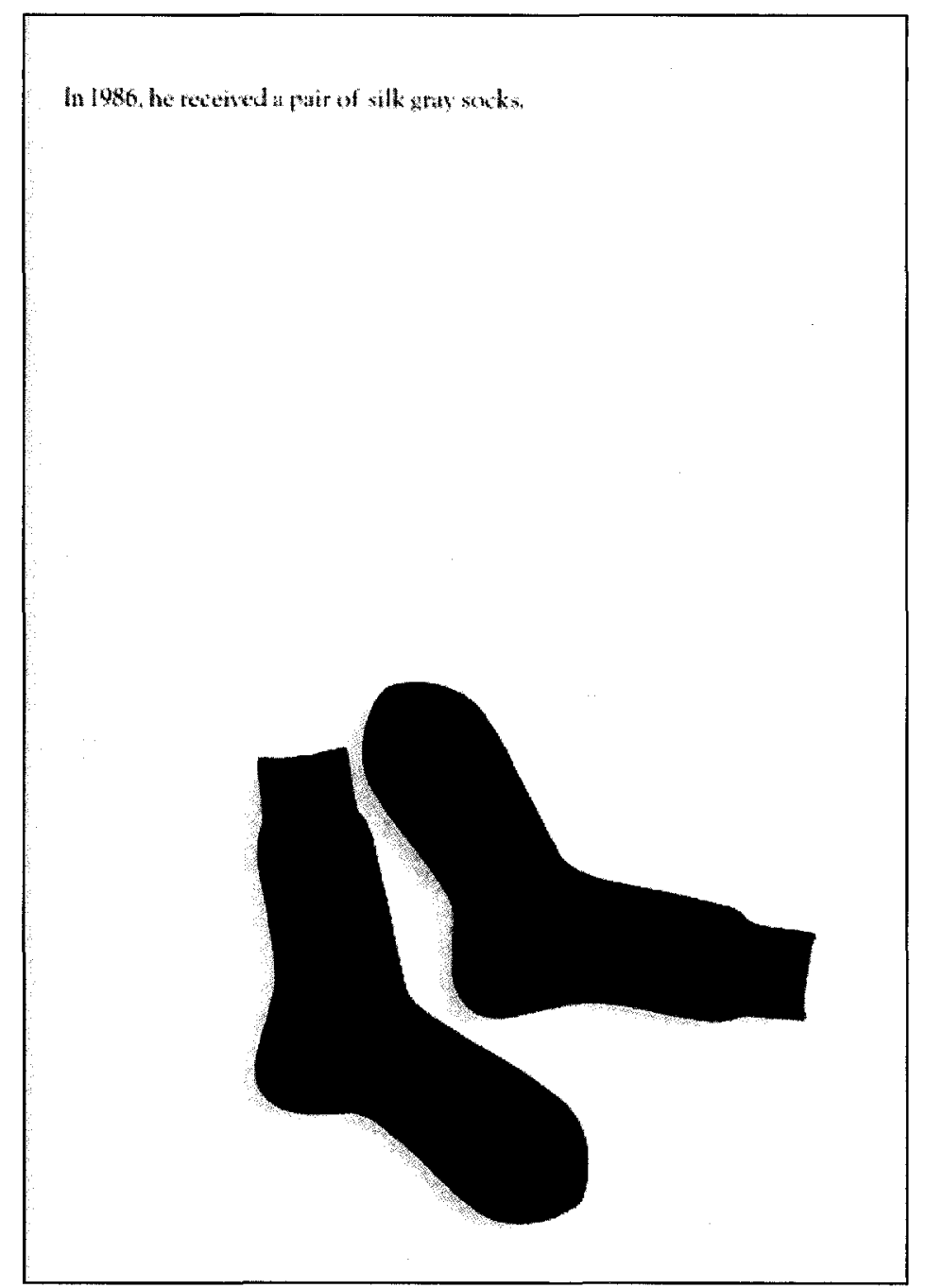

Figure 9.

Calle, "In 1986, he received a pair of silk grey socks." The Wardrobe, Double Game, 37. 
ROOM 29

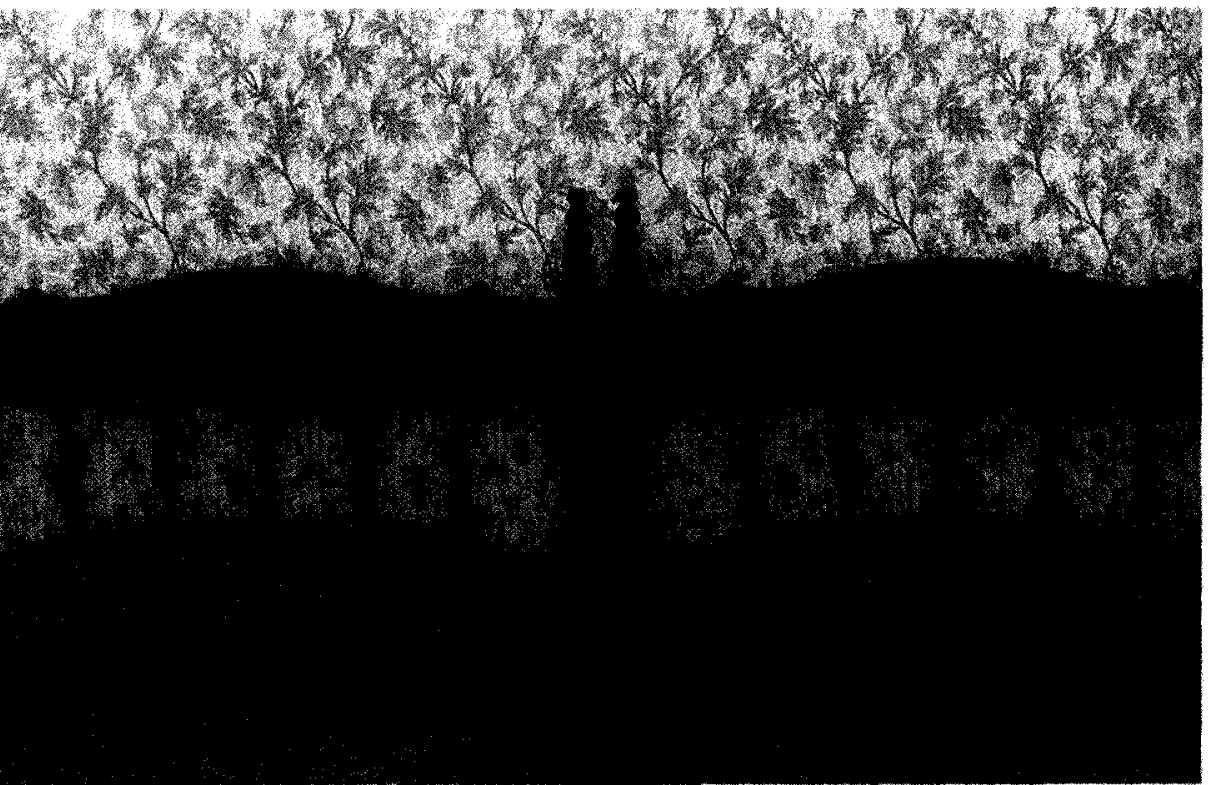

$\mathrm{ROOM} 43$

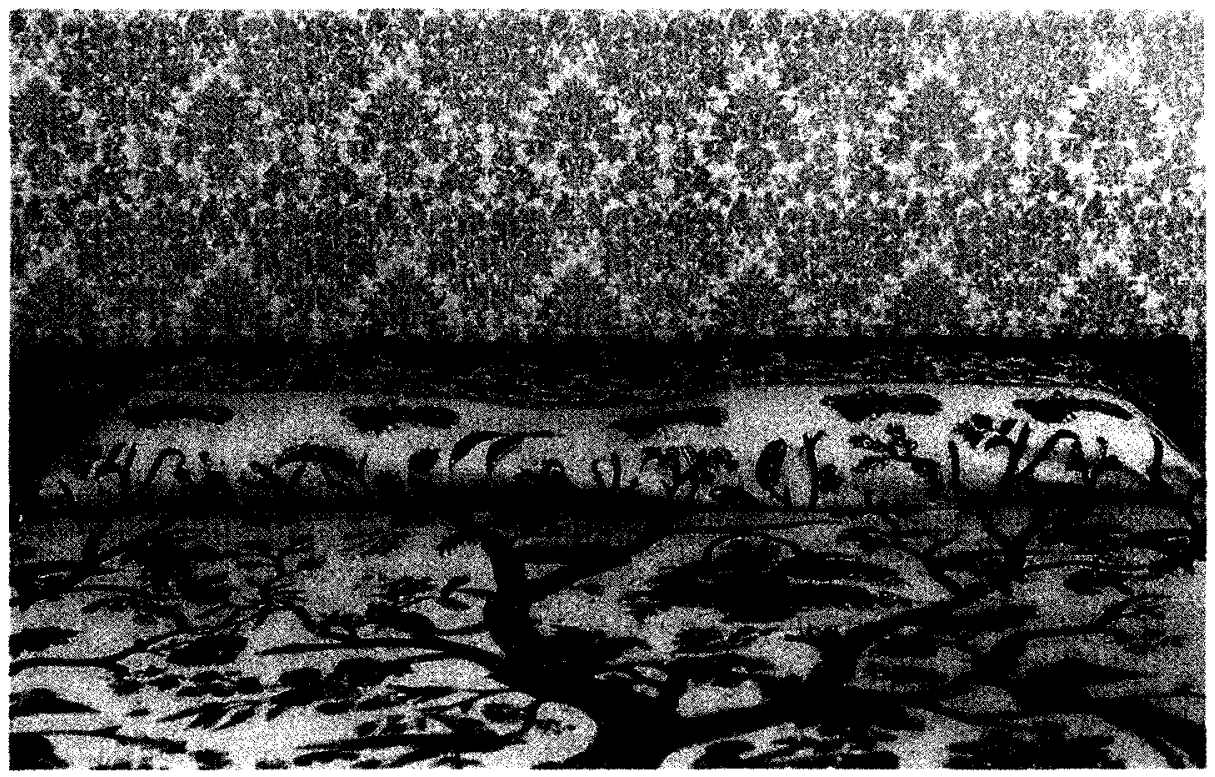

Figure 10.

Calle, The Hotel, Double Game, 180 and 176. 
Khimasia, 98

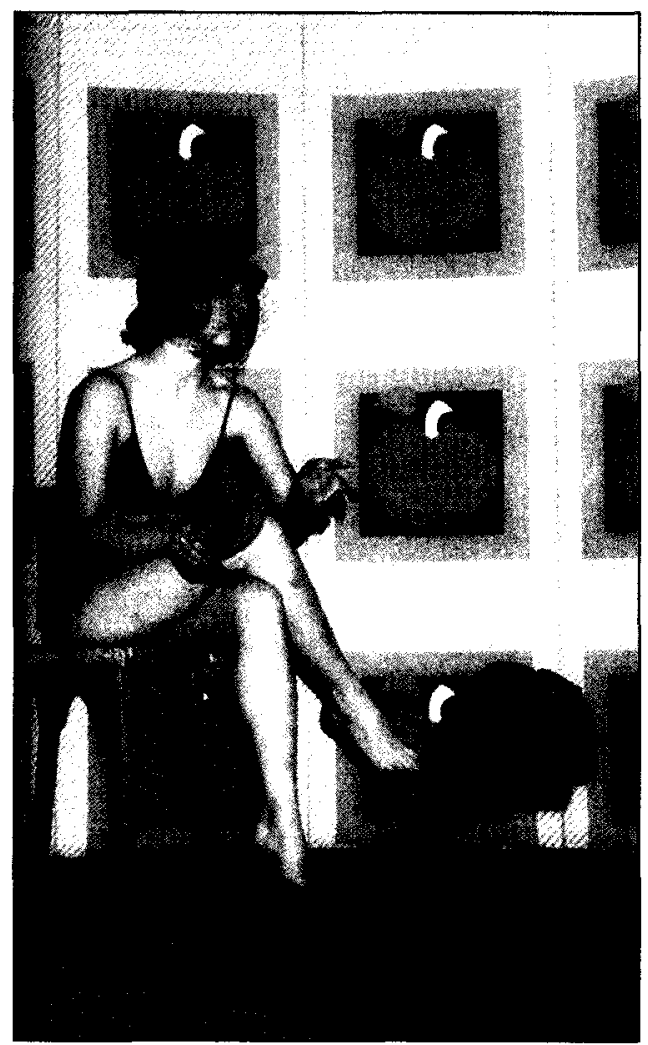

Figure 11.

Sophie Calle, The Striptease, Double Game, 59.

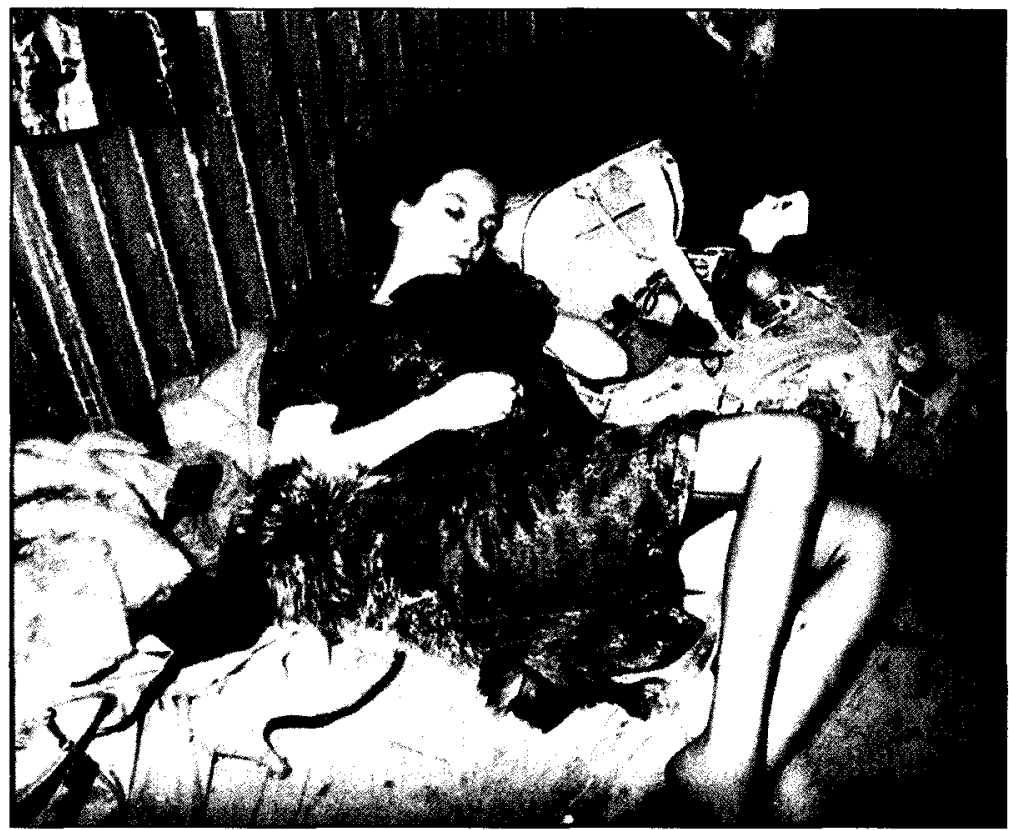

Figure 12.

Sophie Calle, The Striptease, Double Game, 67. 


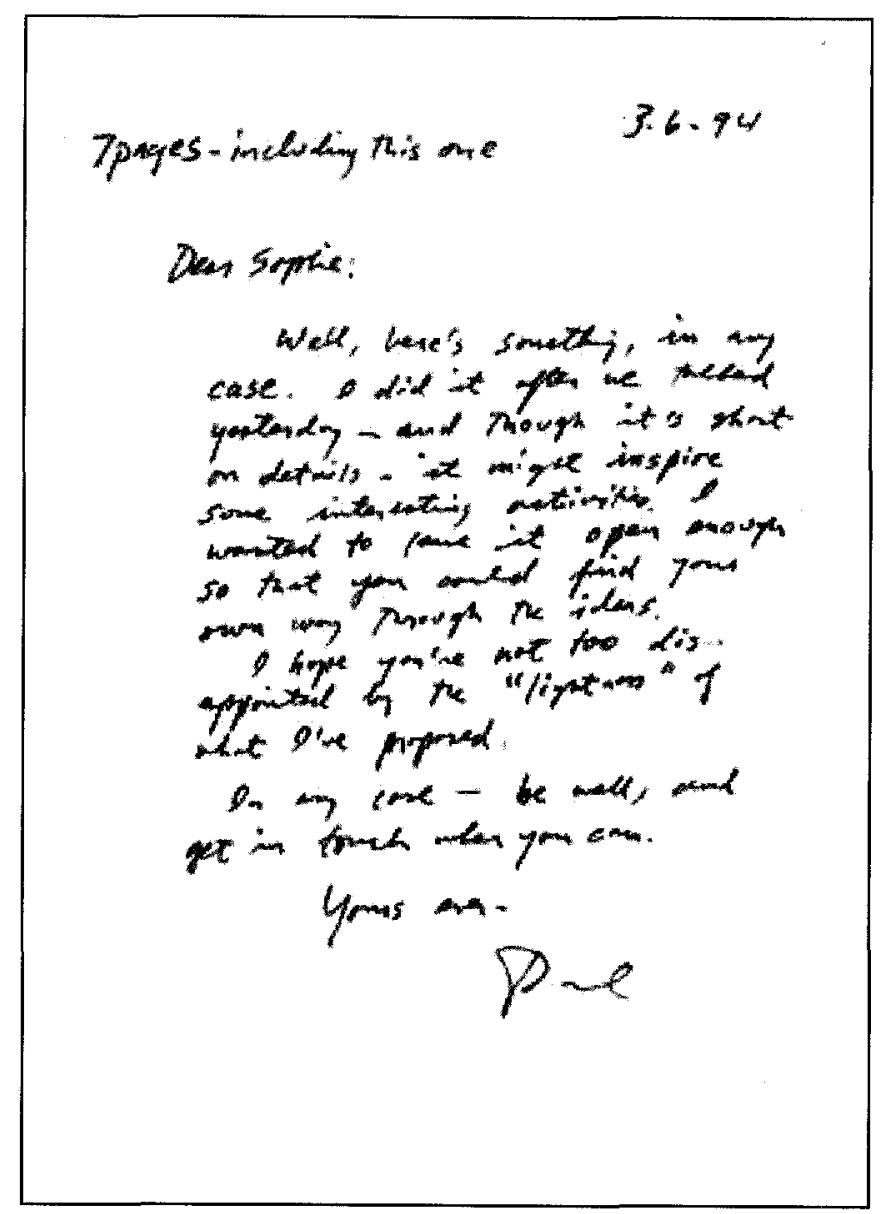

Figure 13.

Paul Auster, Letter to Sophie Calle, Double Game, 237.

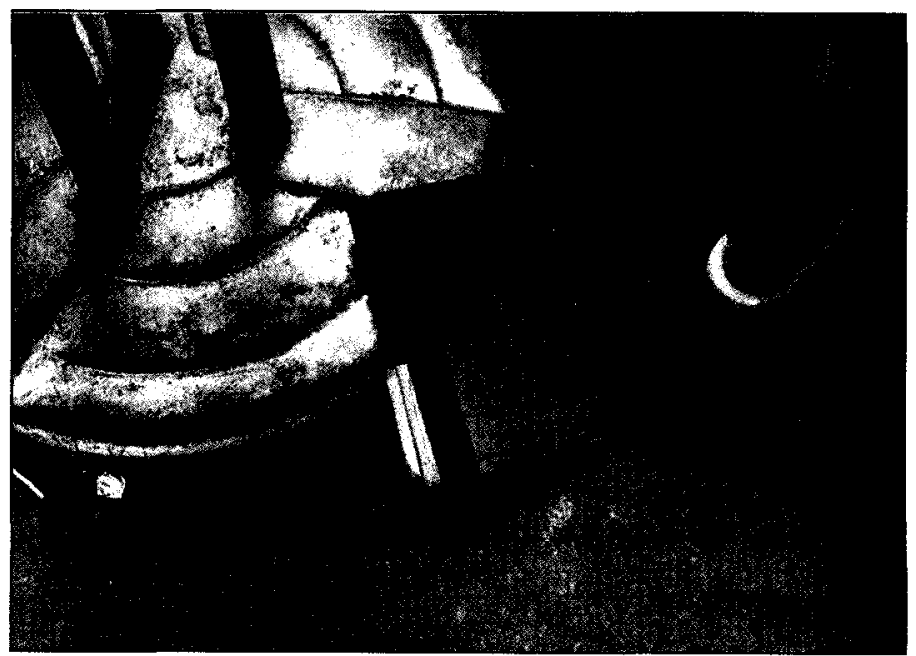

Figure 14.

Calle, The Address Book, Double Game, Page 188. 


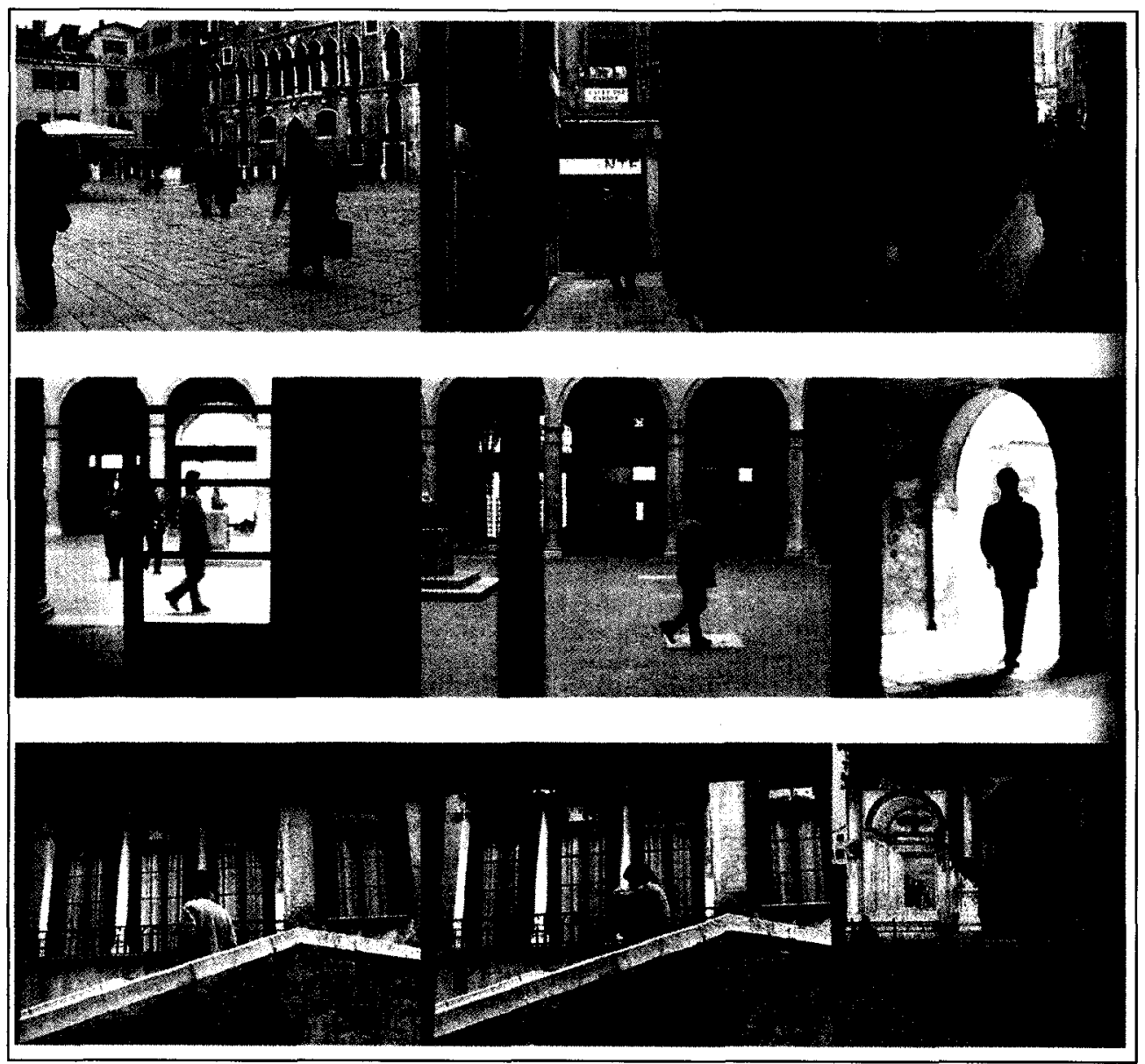

Figure 15.

Calle, Suite vénetienne, Double Game,102.

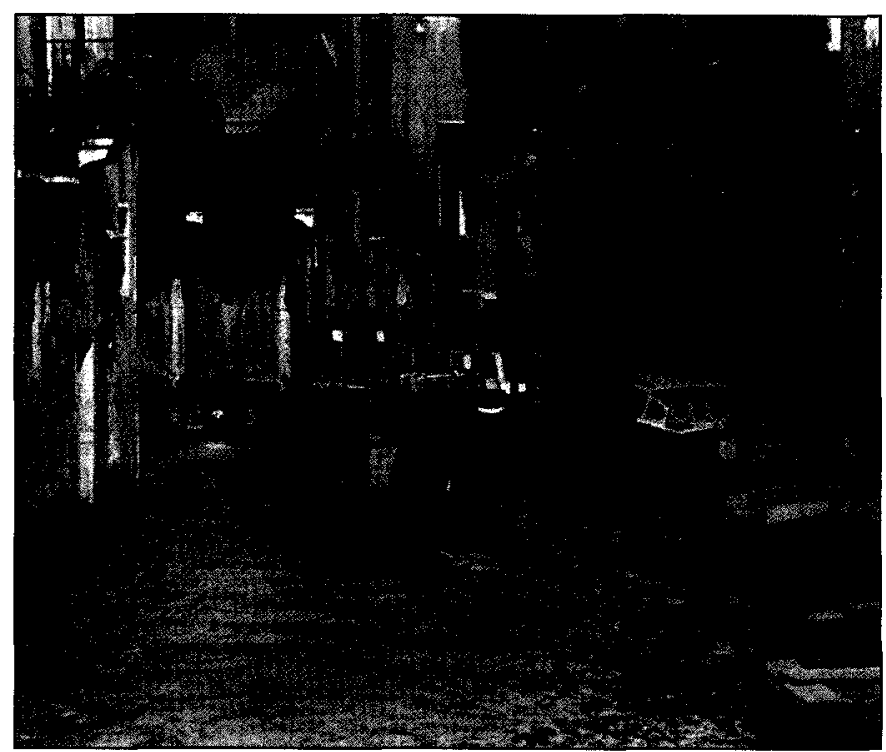

Figure 16.

Sophie Calle, Suite vénitienne, Double Game, Page 95. 


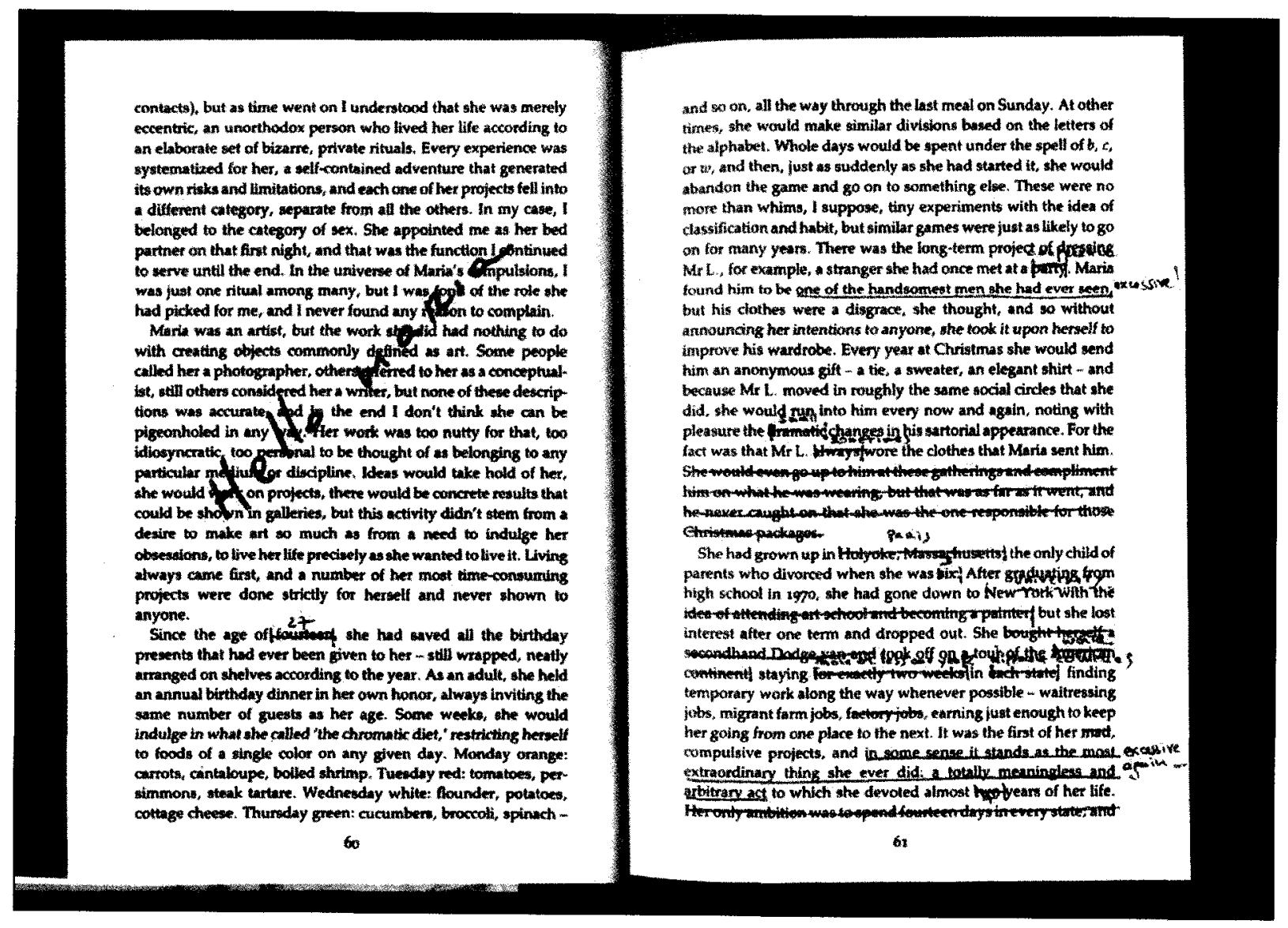

Figure 17.

Calle, Pages from Leviathan, Double Game, insert between pages 8 and 9. 


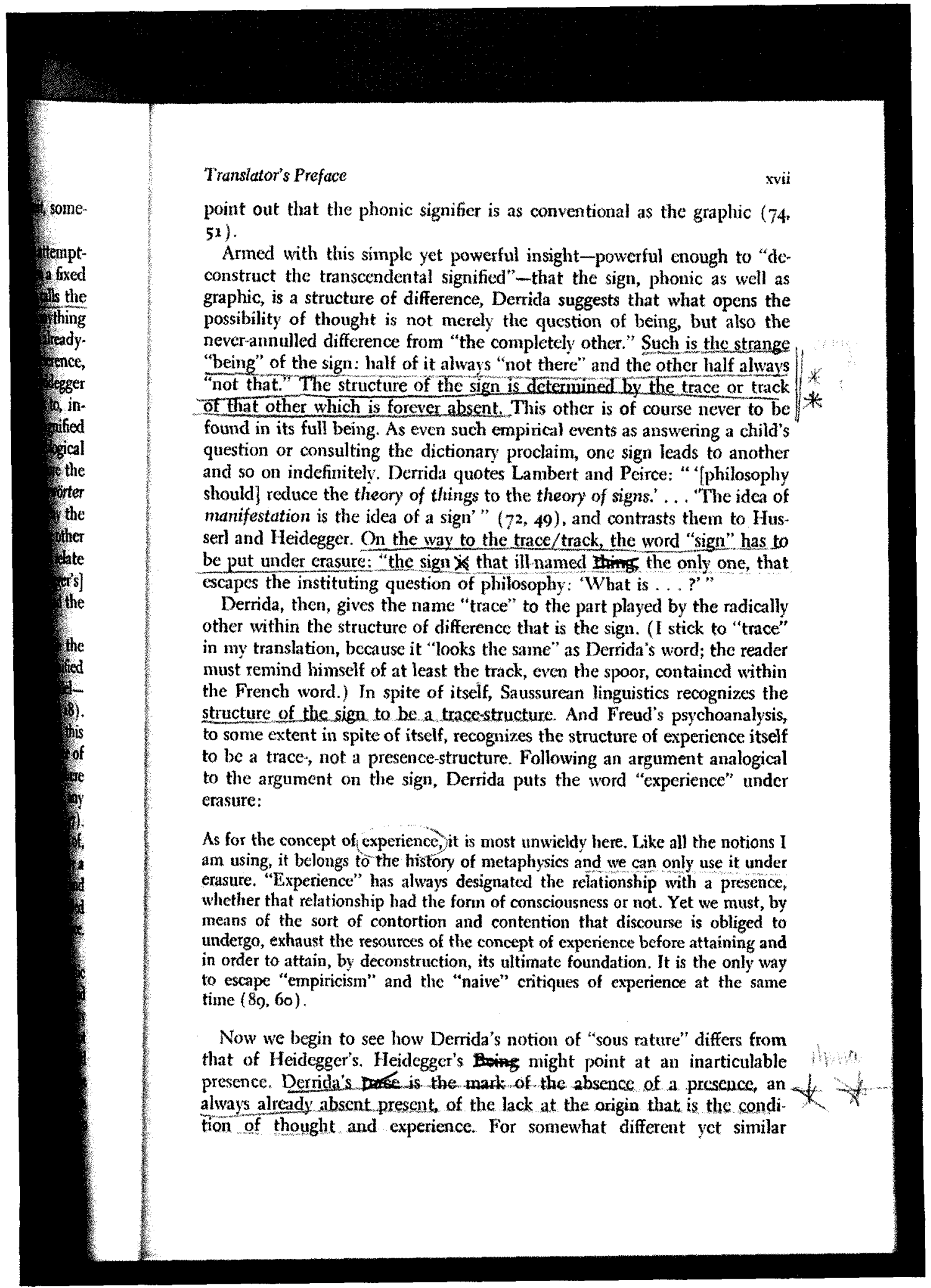

Figure 18.

My notes on Spivak writing about Derrida, "Translator's Preface," Of Gramatology., xvii. 


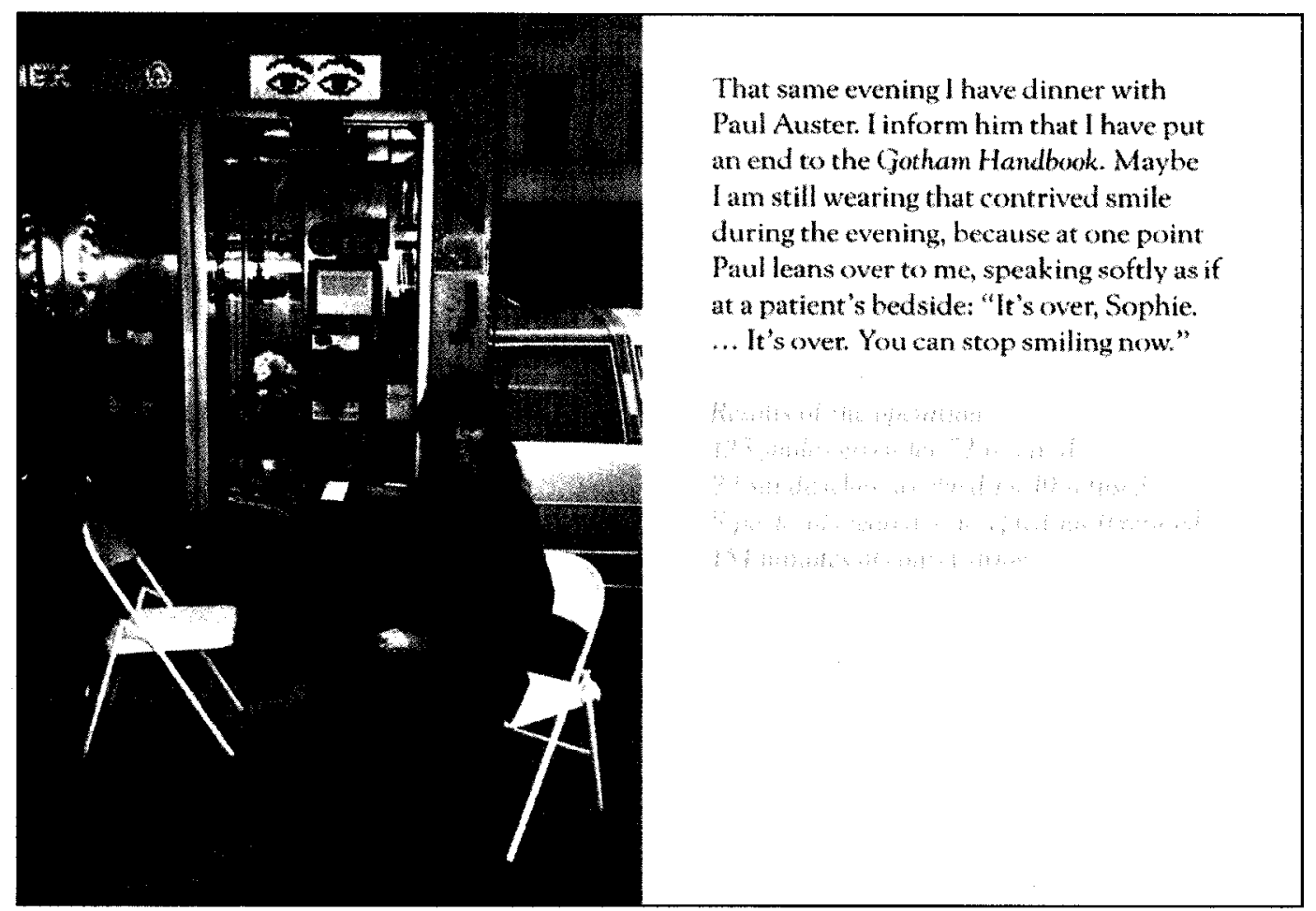

Figure 19.

Calle, Gotham Handbook, Double Game, 292-293.

\section{Paais}

She had grown up in Holyoke, Massaychusettst the only child of parents who divorced when she was bix/After graduating fom high school in 1970, she had gone down to New rootk with thé ide fattending artschoot and beconting a painter| but she lost interest after one term and dropped out. She bought hysetta

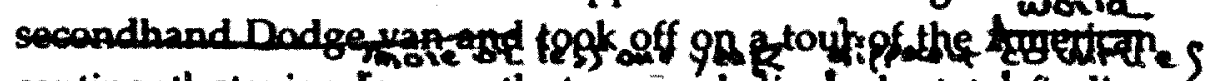
continent staying lor-xectly two weekstin tachstatel finding temporary work along the way whenever possible - waitressing jobs, migrant farm jobs, faeteryjobs, earning just enough to keep her going from one place to the next. It was the first of her mad, compulsive projects, and in some sense it stands as the most excessive extraordinary thing she ever did: a totally meaningless_and. again arbitrary act to which she devoted almost tyears of her life. Heronty ambition was to pend fourteendaysineverystate, and"

61

Figure 20.

Calle, Pages from Leviathan, Double Game, insert between pages 8 and 9. 


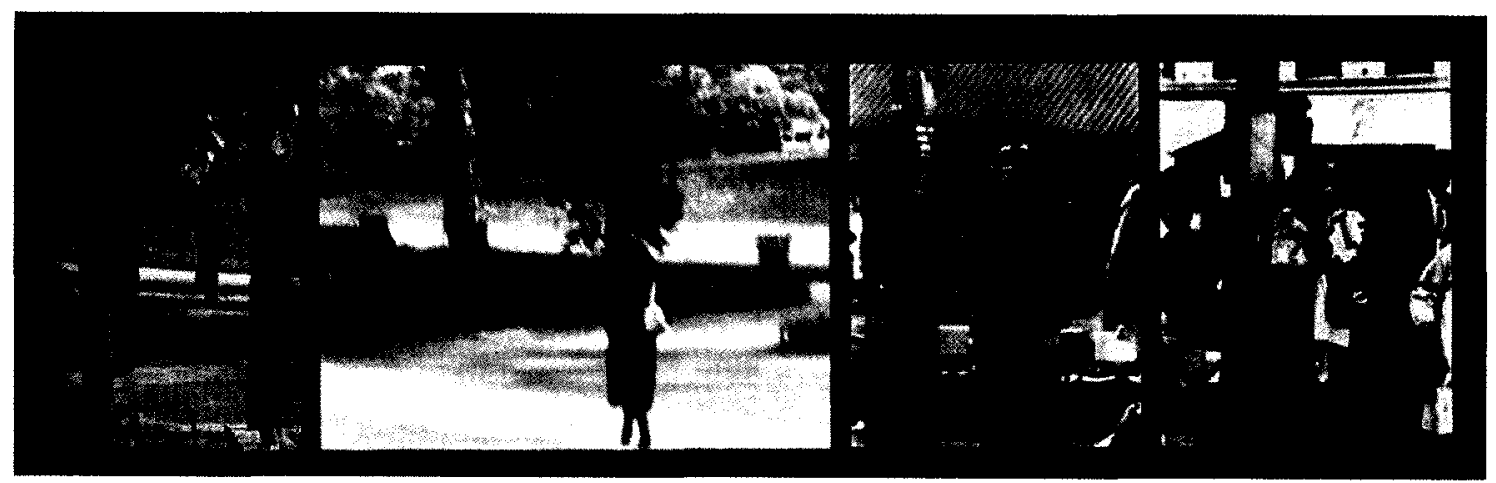

Figure 21.

Calle, The Detective, Double Game, 95.

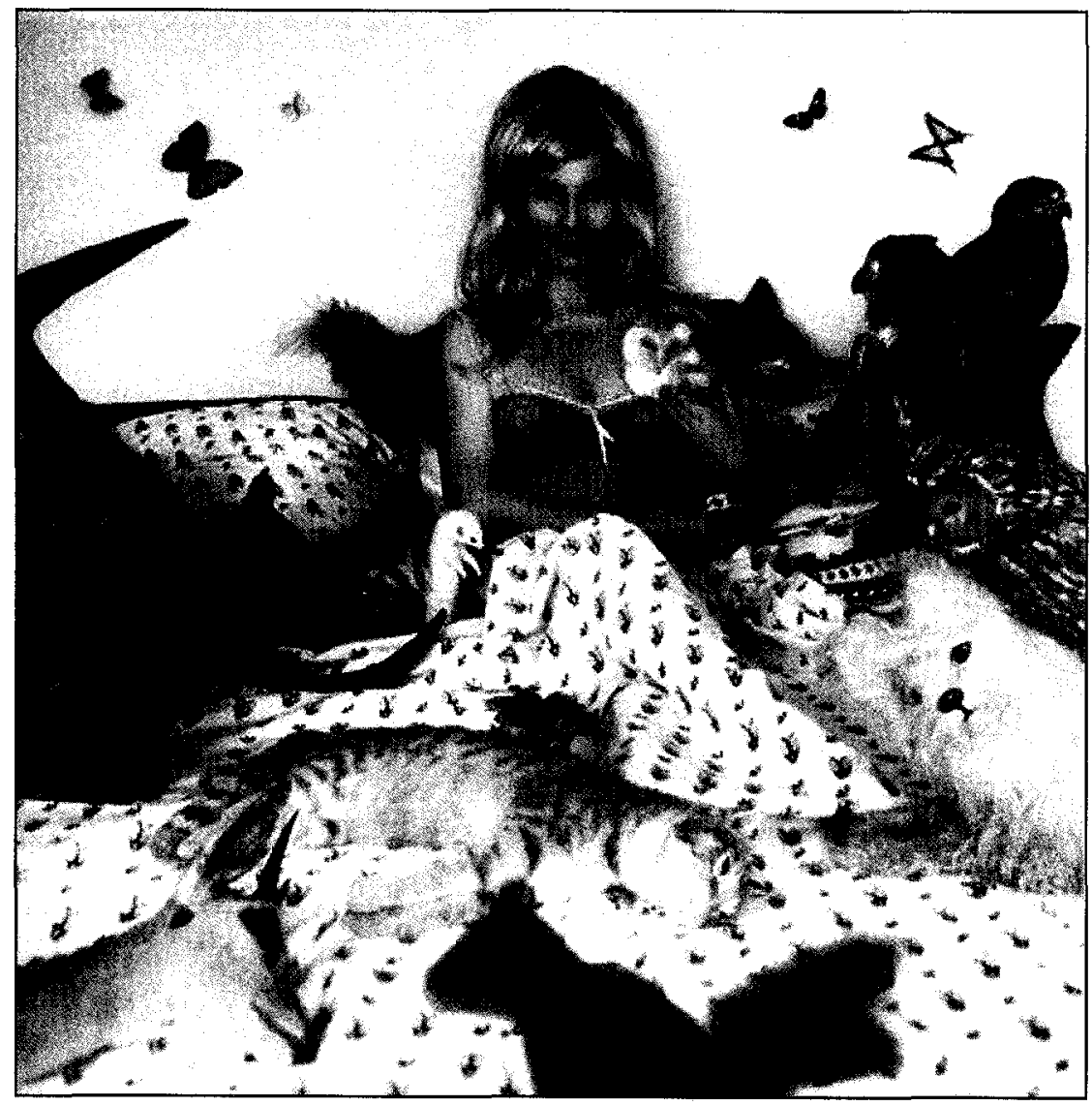

Figure 22.

Calle, Under the Sign of B, C \& W, Double Game, 25. 


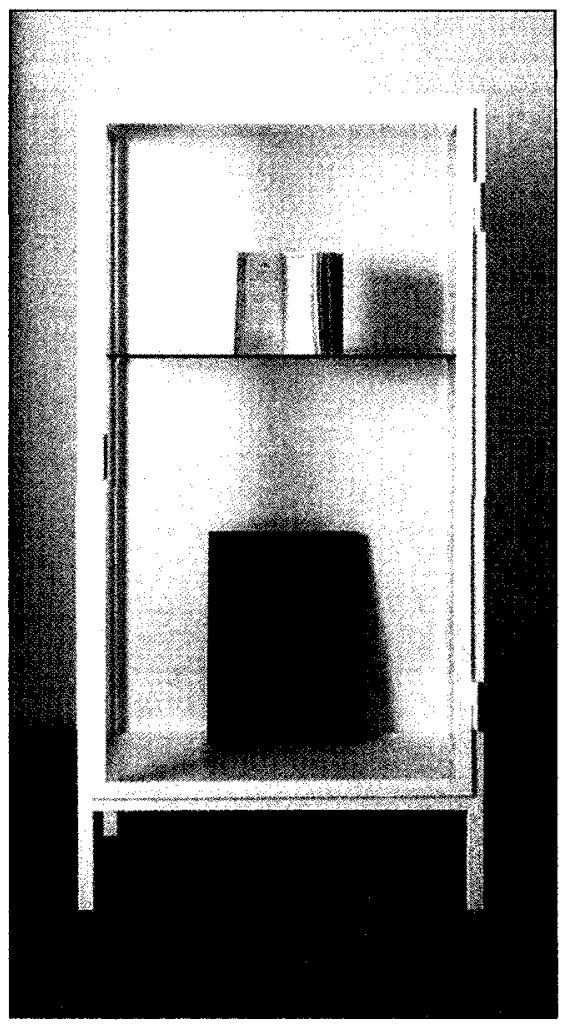

Figure 23.

Calle, The Birthday Ceremony, Double Game, 205.

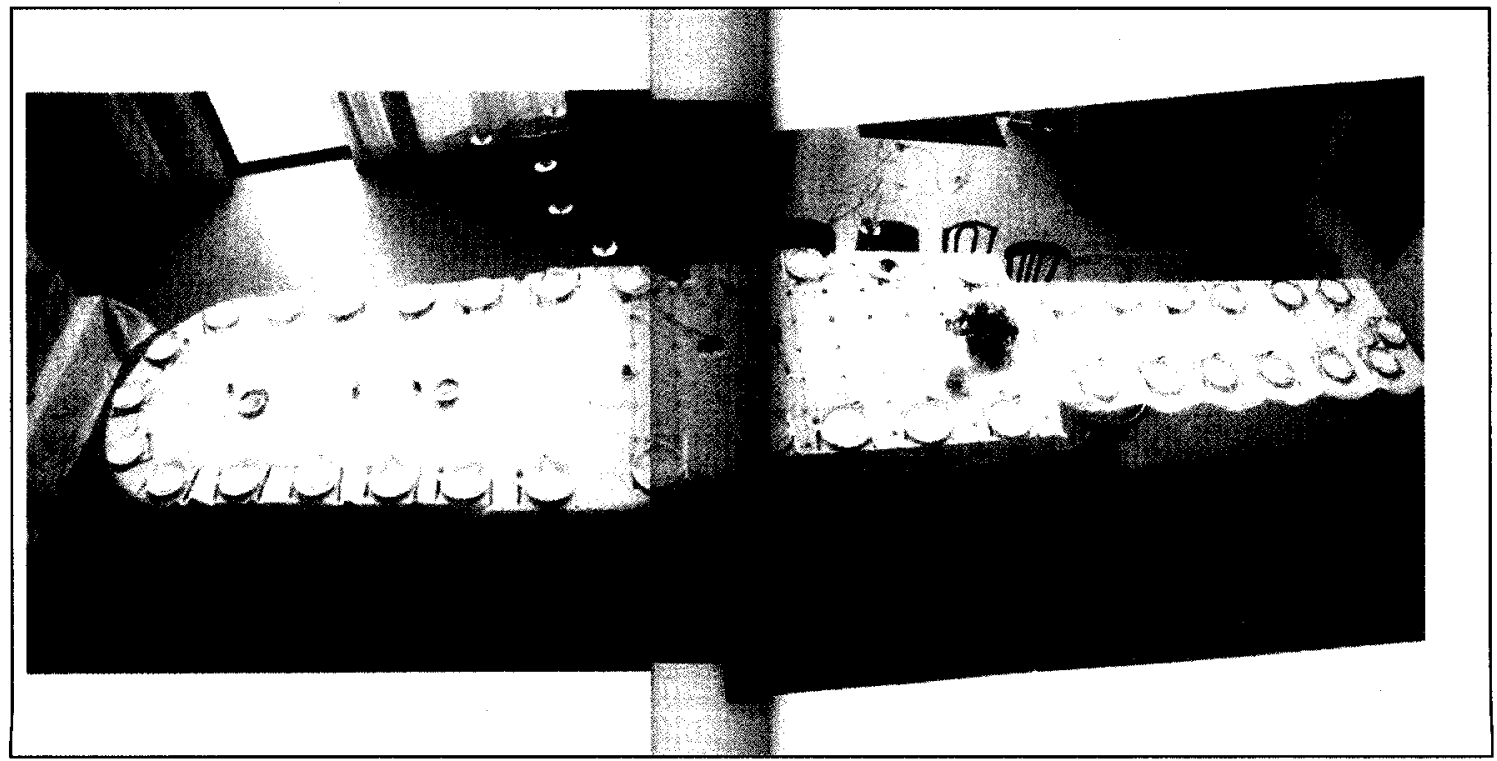

Figure 24.

Calle, The Birthday Ceremony, Double Game, 198-199. 


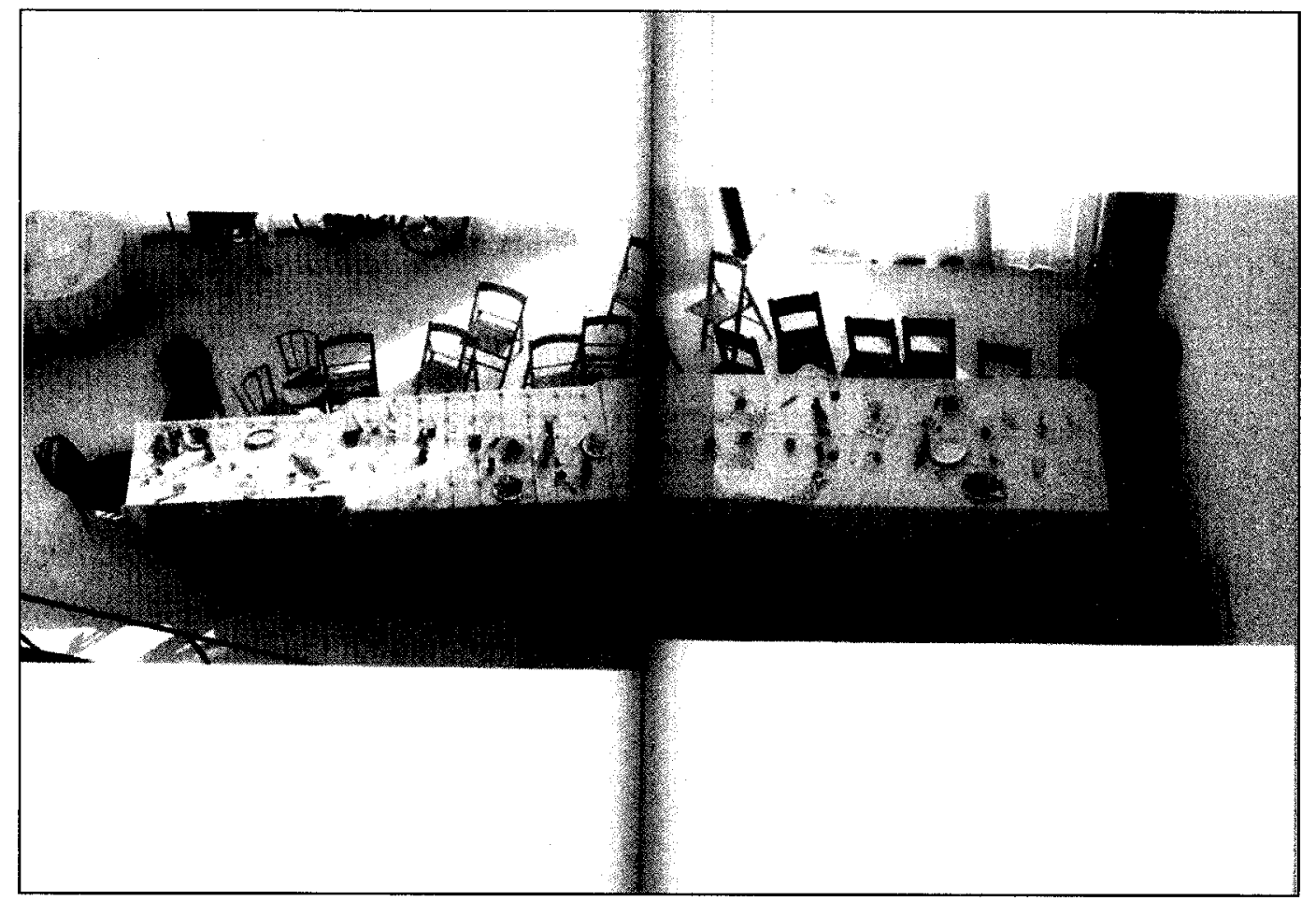

Figure 25.

Calle, The Birthday Ceremony, Double Game, 230-231.

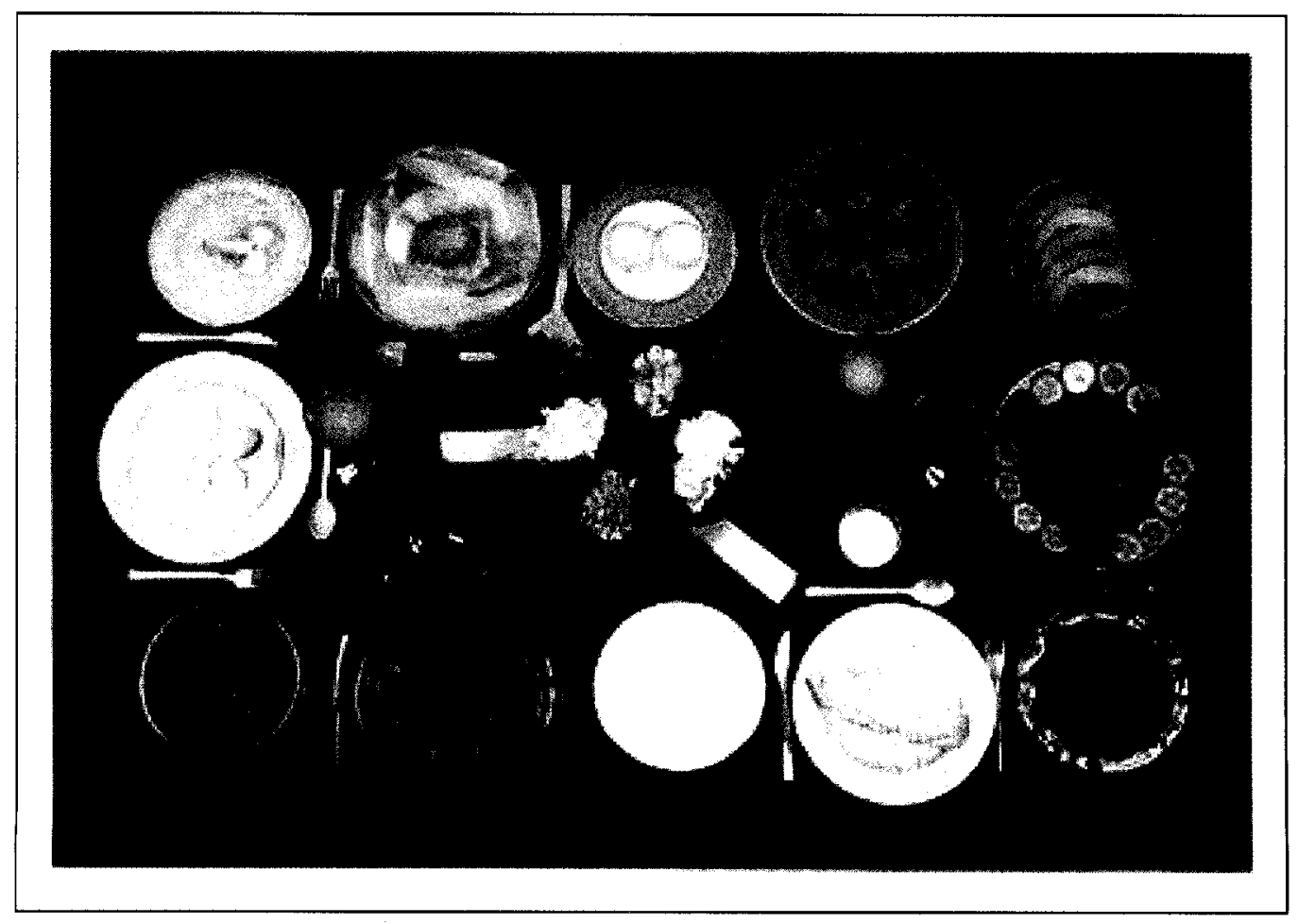

Figure 26.

Calle, The Chromatic Diet, Double Game, 20-21. 
I wanted to have a sowvenir of the person who would be following me. Ididn't know which day of the week the tailing would rake place, sol asked Francois $M$ to be outside the Palais de la Découverte every day at 5P. M. and to photugraph anyone who seemed to be tailing me. 1 received the following report, accompanied by a set of photographs: "Thursday, April 16,1981, at about 5:15 P.M., Sophie Calle came out of the Palais de la Decouverte. I immediately noticed that she was being followed by a young man aged about twentyfive, in a leather jacket, with a camera round his neck and a bag over his shoulder. He was walking about twenty meters behind her and plroto. graphed her at the first crossroads I, in turn, photographed hin. We entered avenue Franklin-Roosevelt and crossed the Champs-Elysées.

"At 5:25 Sophie Calle entered the Gutumont-Colise cinema. The man waited for a few moments; 1 think ho was noting the times of the showings. Then he continued on his way up the avenue to the Lord Byron, where the poster had Enmanuelle and The Daughters of Madame D.

"At 5:30 the man went into the cinema and that was the last I saw of him."
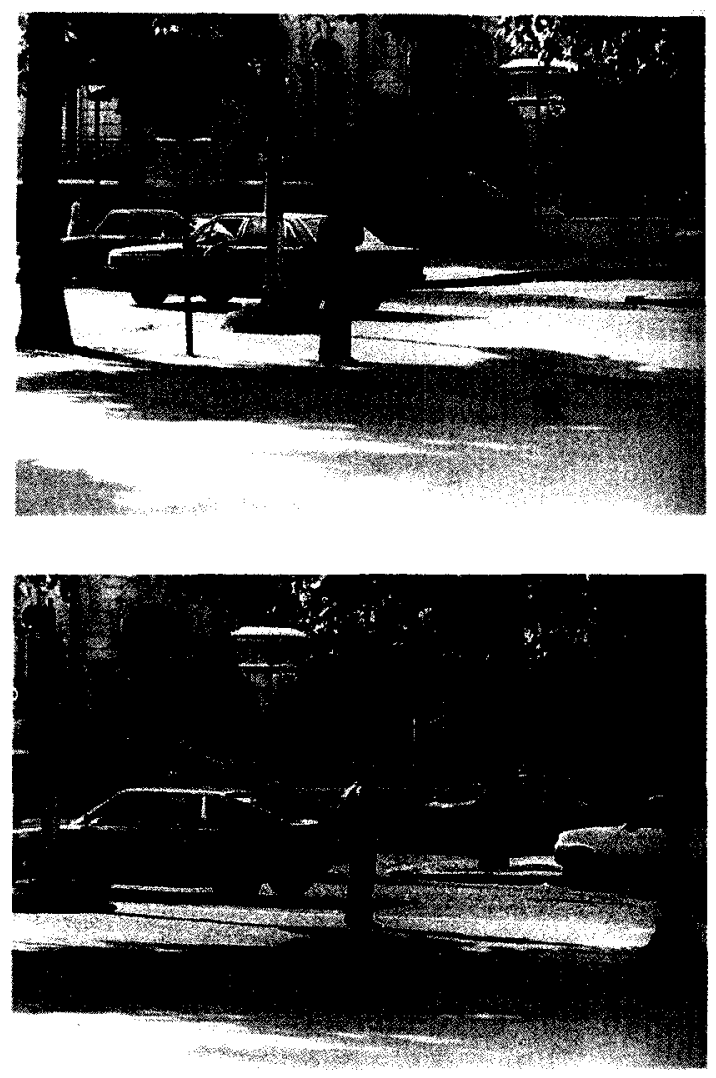

Figure 27.

Calle, The Detective, Double Game, 138. 
Khimasia, 108

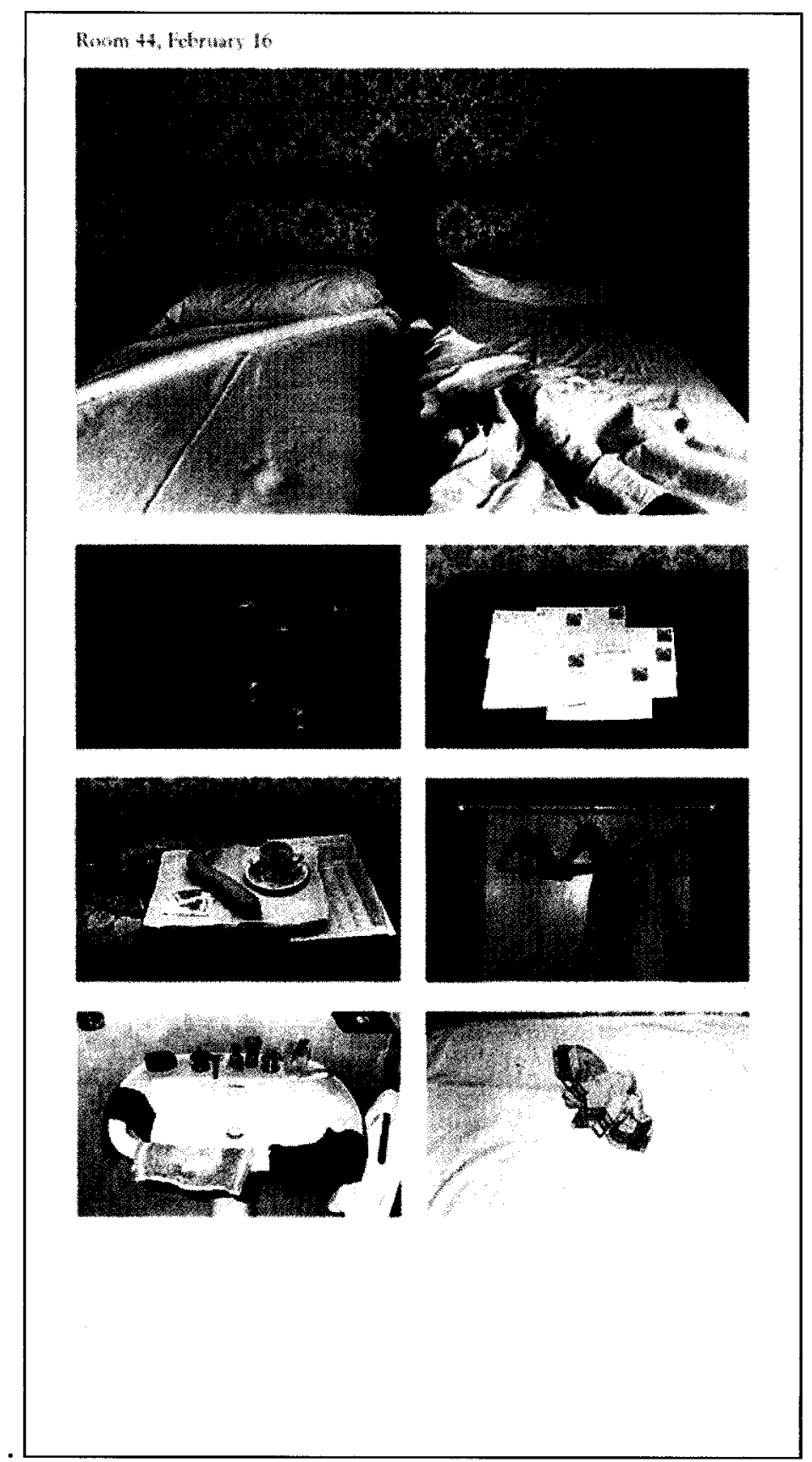

Figure 28.

Calle, Room 44, The Hotel, Double Game, 151. 


\section{Selected Bibliography}

Angot, Christine. "Sophie Calle: No Sex." Beaux Arts Magazine, no. 234 (November 2003): 80-83.

Asselin, Olivier and Johanne Lamoureux. "Autofictions, or Elective Identities." Parachute, no. 105 (January - March 2002): 11-18.

Auster, Paul. Leviathan. USA: Penguin Books, 1992. The New York Trilogy. New York: Penguin Books, 1990. 2002.

The Red Notebook: True Stories. New York: New Directions Books,

Barone, Dennis Ed. Beyond the Red Notebook: Essays on Paul Auster. Philadelphia: University of Pennsylvania Press, 1995.

"Introduction: Paul Auster and the Post Modern American Novel." In Beyond the Red Notebook: Essays on Paul Auster, 1-26. Philadelphia: University of Pennsylvania Press, 1995.

Barthes, Roland. Camera Lucida: Reflections on Photography. Translated by Richard Howard. New York: Farrar, Strauss and Giroux, 1981.

"The Death of the Author." In The Rustle of Language, 49-55. Translated by Richard Howard. Berkley and Los Angeles: University of Californian Press, 1986.

Roland Barthes by Roland Barthes. Translated by Richard Howard. New York: Farrar, Strauss and Giroux, 1977.

Baudrillard, Jean. "Please Follow Me." In Suite vénitienne, 76-86. Seattle: Bay Press. 1988.

Benjamin, Walter. "The Storyteller." Illuminations, edited by Hannah Arendt and translated by Harry Zohn. 83-110. New York: Shocken Books, 1969.

The Correspondence of Walter Benjamin, 1910-1940. Edited by Gershom Scholem and Theodor W. Adorno. Translated by Manfred R. Jacobson and Evelyn M. Jacobson. Chicago: University of Chicago Press, 1994.

Bernstein, Stephen. "The Question is the Story Itself': Postmodernism and Intertextuality in Auster's New York Trilogy." In Detecting Texts: The 
Metaphysical Detective Story from Poe to Postmodernism. Edited by Patricia Merivale and Susan Elizabeth Sweeny. 134-151. Philadelphia, Pennsylvania: Pennsylvania Press, 1999

Bois, Yves-Alain. "The Paper Tigress." October, 116 (Spring 2006): 35-54.

"Character Study." Antforum International, volume 38, no. 8 (April 2000):126-131.

Briggs, Robert. "Wrong Numbers: The Endless Fiction of Auster and Deleuze and Guttari and...." Critique, Vol. 44 No. 2 (Winter 2003): 213- 224.

Burke, Sean. The Death and Return of the Author: Criticism and Subjectivity in Barthes, Foucault and Derrida. Edinburgh: Edinburgh University Press, 1992.

Calle, Sophie with the participation of Paul Auster. Double Game. London: Violette Editions, 1999.

Des Histoires Vraies. France: Actes Sud, 1994.

Camart, Cécile. "Sophie Calle 1978-1981: Genèse d'une figure d'artiste." Les Cahiers du Mnam, 85 (Fall 2003): 51-77.

"Sophie Calle, alias Sophie Calle: Le «Je» d'un narcisse éclaté." Art Press (France), Hors série (April 2002): 15-21.

Contat, Michel and Alyson Waters. "The Manuscript in the Book." Yale French Studies, no. 89 (1996): 160-187.

Chadwick, Whitney. "Body as Subject: Four Contemporary Women Artists." In Beyond French Feminisms: Debates on Women, Politics and Culture in France, 1981-2001. Edited by Roger Célestin, Eliane Dalmolin and Isabelle de Courtivron, 143-153. New York: Palgrave MacMillan, 2003.

Chénetier, Marc. "Paul Auster's Pseudonymous World." In Beyond the Red Notebook: Essays on Paul Auster. Edited by Dennis Barone, 34-43. Philadelphia: University of Pennsylvania Press, 1995.

Cousineau, Penny. "In my Fantasies, I'm the Man,' Sophie Calle's True Stories." Parachute, no. 81 (April - June 1996):11-15.

Culler, Jonathan. On Deconstruction: Theory and Criticism after Structuralism. USA: Cornell University Press, 1982. 
Derrida, Jacques, "Différance." In Margins of Philosophy. Translated by Alan Bass, 1-28. Chicago: University of Chicago Press, 1982.

Of Grammatology. Translated by Alan Bass. USA: Johns Hopkins University Press, 1974.

Writing and Difference. Translated by Alan Bass. Chicago: University of Chicago Press, 1978.

. "Signature Event Context." In Limited Inc. Edited by Gerald Graff. Translated by Samuel Weber, 1-23. Evanston: Northwestern University Press, 1988.

The Ear of the Other. Translated by Peggy Kamuf. USA : Schocken Books, 1985.

Donovan, Christopher. "'Entropy and Efflorescence': To and From the Zero in the Early Novels of Paul Auster." In Postmodern Counternarratives: Irony and Audience in the Novels of Paul Auster, Charles Johnson and Tim O'Brien, 71-96. New York and London: Routledge, 2005.

Doubrovsky, Serge. Autobiographiques: de Corneille à Sartre. Paris: Presses universitaires de France, 1988.

Eakin, Paul John. Fictions in Autobiography: Studies in the Art of Self-Invention. Princeton, New Jersey, Princeton University Press, 1985.

Foucault, Michel. The Order of Things: An Archeology of the Human Sciences. New York: Vintage Books, 1973.

"What is an Author?" In The Art of Art History, edited by Donald Preziosi, 299-313. New York: Oxford University Press, 1998. The Final Foucault. Cambridge Massachusetts, 1988.

"Postscript: An Interview with Michel Foucault by Charles Raus." In Death and the Labyrinth: The World of Raymond Roussel. Translated by Charles Raus. London: Athena Press, 1987.

Gaggi, Silvio. From Text to Hypertext: Decentering the Subject in Fiction, Film, the Visual Arts and Electronic Media. Philadelphia: University of Pennsylvannia Press, 1997.

Geralnik, Nehama. Sophie Calle: True Stories. Exhibition Catalogue, 218-209. Tel Aviv: Tel Aviv Museum of Art, 1997.

Gratton, Johnnie. "Experiment and experience in the phototextual projects of 
Sophie Calle." In Women's Writing in Contemporary France. Edited by Gill Rye and Michael Worton, 157-170. Manchester and New York:

Manchester University Press, 2002.

"Du documentaire au documontage: Vingt ans après de Sophie Calle." Intermédialités: filer (Sophie Calle), numero 7 (printemps 2006):167-179.

. "Sophie Calle's Des Histoires Vraies: Irony and Beyond." In Phototextualities: Intersections of Photography and Narrative. Edited by Alex Hughes and Andrea Noble, 191-197. Albuquerque: University of New Mexico Press, 2003.

Grace, Victoria. "The Fictions of Identity, Power and Desire." In Baudrillard's Challenge: A Feminist Reader, 36-76. London and New York: Routledge, 2000.

Griffith, Jeanine. "Watching the Detectives: Sophie Calle and Paul Auster." Creative Camera (U.K.), no. 354 (Oct.-Nov. 1998): 16-19.

Hall, Stuart. "Who Needs Identity?" In Identity: A Reader. Edited by Paul du Gay, Jessica Evans and Peter Redman, 15-30. London, Thousand Oaks, New Delhi: Sage Publications, 2000.

Hand, Janet. "Sophie Calle's Art of Following and Seduction." Cultural Geographies, no. 12 (2005): 463-484.

Hollander, Dana. "Puncturing Genres: Barthes and Derrida on the Limits of Representation." In Panorama: Philosophies of the Visible, edited by Wilhelm Wurzer, 34-42. New York and London: Continuum, 2007.

Iser, Wolfgang. "Feigning in Fiction." In Identity of the Literary Text. Edited by Mario J. Valdes and Owen Miller, 204-228. Toronto, Buffalo, London: University of Toronto Press, 1985.

Jones, Amelia. "'Presence' in Absentia: Experiencing Performance as Documentation," in Art Journal. Vol. 56, no.4: 11-18.

Body Art: Performing the Subject. Minneapolis: University of Minnesota Press, 1998.

Kaprow, Allan. Essays on the Blurring of Art and Life. Berkley, Los Angeles, London: University of California Press, 1993.

Lejeune, Philippe. On Autobiography. Minneapolis: University of Minnesota Press, 1989. 
Lodge, David. After Bakhtin: Essays on Fiction and Criticism. London and New York. Routledge, 1990.

Lucy, Niall. A Derrida Dictionary. UK: Blackwell Publishing, 2004. . Postmodern Literary Theory. Oxford: Blackwell Publishers Ltd., 1997.

Lury, Celia. Prosthetic Culture: Photography, Memory and Identity. London and New York: Routledge, 1998.

Macel, Christine ed. Sophie Calle, M'as-tu vue. Paris: Centre National d'Art et de Culture Georges Pompidou, 2003.

. "The Author Issue in the Work of Sophie Calle. Unfinished." In Sophie Calle, M'as-tu vue, edited by Christine Macel, 17-28. Paris: Centre National d'Art et de Culture Georges Pompidou, 2003.

McQuillan, Martin. "Introduction: Five Strategies for Deconstruction." In Deconstruction: A Reader. Edited by Martin McQuillan, 1-46. New York: Routledge, 2000.

Merivale, Patricia and Susan Elizabeth Sweeny. "The Game's Afoot: On the Trail of the Metaphysical Detective Story." In Detecting Texts: The Metaphysical Detective Story from Poe to Postmodernism. Edited by Patricia Merivale and Susan Elizabeth Sweeny.1-26. Philadelphia, Pennsylvania: Pennsylvania Press, 1999.

McAuliffe, Chris. "It's Okay, I'm an Artist: Sophie Calle's Photographs." In Binocular: Focusing, Writing, Vision. Edited by Ewen McDonald and Juliana Engberg, 33-44. France: Moët \& Chandon Contemporary Edition, 1991.

McDonough, Tom. "No Ghost." October, no. 110 (Fall 2004): 107-130.

Miller, Owen. "Intertextual Identity." In Identity of the Literary Text, edited by Mario J. Valdes and Owen Miller, 19-40. Toronto, Buffalo, London: University of Toronto Press, 1985.

Moi, Toril. Sexual/Textual Politics: Feminist Literary Theory. London and New York: Routledge, 1985.

Nealon, Jeffery. "Work of the Detective, Work of the Writer: Paul Auster's City of Glass." Modern Fiction Studies, no. 42.1 (1996): 91-110. 
Norris, Christopher. Deconstruction: Theory and Practice. London and New York: Routledge, 1982.

Peacock, Jim. "Carrying the Burden of Representation: Paul Auster's The Book of Illusions." Journal of American Studies, 40, 1 (2006): 53-69.

Phelan, Peggy. "The ontology of performance: representation without reproduction." In Unmarked: the politics of performance, 146-166. London and New York: Routledge, 1993.

Prinz, Jessica. "It is Such a Relief Not to be Myself': Laurie Anderson's Stories from the Nerve Bible." In Autobiography/lmage and Performance, edited by Sidonie Smith and Julia Watson, 385-405. Ann Arbour: The University of Michigan Press, 2002.

Rabe, Jean-Michel Ed., Writing the Image, After Barthes. Philadelphia: University of Pennsylvania Press, 1997.

Rinder, Lawrence. "A Conversation with Sophie Calle." CALENDAR. Berkeley: University Art Museum, 1990. no page numbers.

. "Sophie Calle and the Practice of Doubt." In Art Life: Selected Writings, 1991-2005.11-20. New York: Gregory R. Miller and Company, 2005.

Riding, Alan. "Keeping it Together by Living her Life in Public." New York Times, Arts and Leisure, December 7, 2003. 44-45.

Rolin, Olivier. "Beet, Alfalfa, etc." In Sophie Calle, M'as-tu vue, edited by Christine Macel, 137-140. Paris: Centre National d'Art et de Culture Georges Pompidou, 2003.

Russell, Alison. "Deconstructing The New York Trilogy. Paul Auster's AntiDetective Fiction." Critique volume 31, Issue 2 (Winter 1990): 71-84.

Sadoux, Marion. "Christine Angot's autofictions: literature and/or reality?" In Women's Writing in Contemporary France. Edited by Gill Rye, Michael Worton, 171-181. Manchester and New York: Manchester University Press, 2002.

Sallis, John. "Doublings." In Derrida: A Critical Reader. Edited by David Wood, 120-136. Oxford: Blackwell Publishers, 1992.

Saltzman, Arthur. "Post Hoc Harmonies: Paul Auster's Leviathan." In This Mad Instead: Governing Metaphors in Contemporary American Fiction, 63-73. South Carolina: University of South Carolina Press, 2000. 
Schoell-Glass, Charlotte. "Fictions of the Art World: Art, Art History and the Art Historian in Literary Space." In Writing and Seeing: Essays on Word and Image. Edited by Rui Carvalho Homen and Maria de Fátima Lambert,107118. Amsterdam and New York: Rodopi, 2006.

Smith, Sidonie and Julia Watson. "Introduction. "In Interfaces: Women/ Autobiography/Image and Performance, edited by Sidonie Smith and Julia Watson, 1-48. Ann Arbour: The University of Michigan Press, 2002.

Sorapure, Madeline. "The Detective and the Author: City of Glass." In Beyond the Red Notebook: Essays on Paul Auster. Edited by Dennis Barone, 7187. Philadelphia: University of Pennsylvania Press, 1995.

Spivak, Gayatri Chakravorty. "Translator's Preface." In Of Grammatology, ix-xc. Baltimore and London: The Johns Hopkins University Press, 1976.

Storr, Robert. "Sophie Calle: la femme qui n'était pas là." Art Press, number 295 (November 2003): 23-28.

Todorov, Tzvetan. Mikhail Bakhtin: The Dialogical Principle. Manchester: Manchester University Press, 1984.

Van Zuylen, Marina. "Voyeuristic Monomania: Sophie Calle's Rituals." In Monomania: The Flight from Everyday Life in Literature and Art., 180-192. USA: Cornell University Press, 2005.

Varvogli, Aliki. The World that is the Book: Paul Auster's Fiction. Liverpool: Liverpool University Press, 2001.

Vice, Sue. Introducing Bakhtin. Manchester, UK: Manchester University Press, 1997.

Walker, Joseph S. "Criminality and (Self) Discipline: The Case of Paul Auster. Modern Fiction Studies, Volume 48, no.2 (Summer 2002): 389-421.

Whitebrook, Maureen. Identity, Narrative and Politics. London and New York: Routledge, 2001.

Wirth, Eric. "A Look Back from the Horizon." In Beyond the Red Notebook: Essays on Paul Auster. Edited by Dennis Barone, 171-182. Philadelphia: University of Pennsylvania Press, 1995.

Wolf, Janet. Feminine Sentences: Essays on Women and Culture. Cambridge: Polity Press, 1990. 
Worthington, Kim. Self as Narrative: Subjectivity and Community in

Contemporary Fiction. Oxford: Oxford University Press, 1996. 